Prepared for the U.S. Department of Energy

under Contract DE-AC05-76RL01830

\title{
Analysis of the Chinese Market for Building Energy Efficiency
}

$\mathrm{SYu}$

M Evans

Q Shi

March 2014

Pacific Northwest

NATIONAL LABORATORY

Proudly Operated by Battelle Since 1965 


\title{
DISCLAIMER
}

This report was prepared as an account of work sponsored by an agency of the United States Government. Neither the United States Government nor any agency thereof, nor Battelle Memorial Institute, nor any of their employees, makes any warranty, express or implied, or assumes any legal liability or responsibility for the accuracy, completeness, or usefulness of any information, apparatus, product, or process diselosed, or represents that its use would not infringe privately owned rights. Reference herein to any specific commercial product, process, or service by trade name, trademark, manufacturer, or otherwise does not necessarily constitute or imply its endorsement, recommendation, or favoring by the United States Government or any agency thereof, or Battelle Memorial Institute. The views and opinions of authors expressed herein do not necessarily state or reflect those of the United States Government or any agency thereof.

\author{
PACIFIC NORTHWEST NATIONAL LABORATORY \\ operated by \\ BATTELLE \\ for the \\ UNITED STATES DEPARTMENT OF ENERGY \\ under Contract DE-AC05-76RL01830 \\ Printed in the United States of America
Available to DOE and DOE contractors from the Office of Scientific and Technical Information,
P.O. Box 62, Oak Ridge, TN 37831-0062;
ph: (865) 576-8401
fax: $(865) 576-5728$
email: reports@adonis.osti.gov

\footnotetext{
Available to the public from the National Technical Information Service, U.S. Department of Commerce, 5285 Port Royal Rd., Springfield, VA 22161 ph: (800) 553-6847 fax: (703) $605-6900$ email: orders@ntis.fedworld.gov online ordering: http://www.ntis.gov/ordering.htm
}

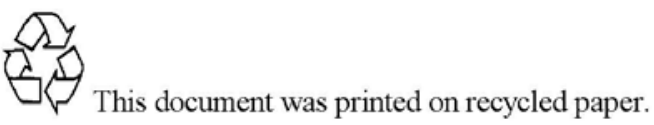




\section{Analysis of the Chinese Market for Building Energy Efficiency}

\section{Executive Summary}

China will account for about half of the new construction globally in the coming decade. Its floorspace doubled from 1996 to 2011, and Chinese rural buildings alone have as much floorspace as all of U.S. residential buildings. Building energy consumption has also grown, increasing by over $40 \%$ since 1990 .

To curb building energy demand, the Chinese government has launched a series of policies and programs. Combined, this growth in buildings and renovations, along with the policies to promote green buildings, are creating a large market for energy efficiency products and services.

This report assesses the impact of China's policies on building energy efficiency and on the market for energy efficiency in the future. The introduction and second chapter of this report introduce the trends in China, drawing on both historical analysis, and detailed modeling of the drivers behind changes in floorspace and building energy demand such as economic and population growth, urbanization, policy. The analysis describes the trends by region, building type, and energy service.

The third chapter discusses China's policies to promote green buildings. China began developing building energy codes in the 1980s. Over time, the central government has increased the stringency of the code requirements and the extent of enforcement. The codes are mandatory in all new buildings and major renovations in China's cities, which means they impact construction of a very large number of buildings. In this way, they have been a driving force behind the expansion of China's markets for insulation, efficient windows, and other green building materials. China also has several other important policies to encourage efficient buildings, including the Three-Star Rating System (somewhat akin to the Leadership in Energy \& Environmental Design), financial incentives tied to efficiency, appliance standards, a phasing out of incandescent bulbs and promotion of efficient lighting, and several policies to encourage retrofits in existing buildings (in particular, residential buildings in northern China and government buildings).

In the fourth chapter, we take “deep dives” into the trends affecting key building components. This chapter examines insulation in walls and roofs; efficient windows and doors; heating, air conditioning and controls; and lighting. These markets have seen significant growth because of the strength of the construction sector but also the specific policies that require and promote efficient building components. At the same time, as requirements have become more stringent, there has been fierce competition, and quality has at time suffered, which in turn has created additional challenges. For example, China has a large number of companies that produce synthetic insulation, but following a series of fires linked to this insulation, the Chinese government pushed to require less-flammable, efficient insulation (such as rock wool or fiberglass). The government is now trying to balance the need for time for the market to adjust production capacity with the need for high-quality, safe products. This creates an excellent opportunity for manufacturers, in particular, international companies, that produce products today that meet these requirements.

Next we examine existing buildings in chapter five. China has many inefficient buildings built before stringent requirements for efficiency were more widely enforced. As a result, there are several specific market opportunities related to retrofits. These fall into two or three categories. First, China now has a code for retrofitting residential buildings in the north. Based on the target set by the central government, 
local governments have targets of the number of buildings they must retrofit each year, and they help finance the changes. The requirements focus on insulation, windows, and heat distribution. Second, the Chinese government recently decided to increase the scale of its retrofits of government and state-owned buildings. It hopes to achieve large-scale changes through energy service contracts, which creates an opportunity for energy service companies. Third, there is also a small but growing trend to apply energy service contracts to large commercial and residential buildings. While most of these contracts today focus on short-term, high impact, single technologies, like lighting, there is growing market and government pressure to deepen and expand these retrofits, and the contracts that implement them.

China is the world's leading market for new construction. The Chinese government has set a goal of at least a 40-45\% reduction in carbon intensity nationwide by 2020, relative to a 2005 baseline, a target in which buildings play a large role. Policies supporting this goal have created a vibrant and growing market for green building products. This market will mature as it grows, likely with a smaller number of highquality producers. 


\begin{tabular}{|c|c|}
\hline \multicolumn{2}{|c|}{ Acronyms and Abbreviations } \\
\hline AQSIQ & $\begin{array}{l}\text { General Administration of Quality Supervision, Inspection and Quarantine, People's } \\
\text { Republic of China }\end{array}$ \\
\hline CAGR & Compound Annual Growth Rate \\
\hline CASBEE & Comprehensive Assessment System for Built Environment Efficiency \\
\hline СCB & China Construction Bank \\
\hline CFL & Compact Fluorescent Lamp \\
\hline COP & Coefficient of Performance \\
\hline ESCO & Energy Service Company \\
\hline EER & Energy Efficiency Ratio \\
\hline EMC & Energy Management Contract \\
\hline EMCA & Energy Management Company Association \\
\hline EPS & Expanded Polystyrene \\
\hline ERI & $\begin{array}{l}\text { Energy Research Institute of the National Development and Reform Commission (NDRC), } \\
\text { People's Republic of China }\end{array}$ \\
\hline EUI & Energy Use Intensity \\
\hline FYP & Five-Year Plan \\
\hline GDP & Gross Domestic Product \\
\hline GEF & Global Environment Facility \\
\hline GOA & Government Offices Administration of the State Council \\
\hline HVAC & Heating, Ventilating and Air Conditioning \\
\hline IEA & International Energy Agency \\
\hline kWh & Kilowatt Hour \\
\hline LED & Light-Emitting Diode \\
\hline LEED & Leadership in Energy and Environmental Design \\
\hline $\operatorname{lm}$ & Lumen \\
\hline $\mathrm{M} \& \mathrm{~V}$ & Measurement and Verification \\
\hline MIIT & Ministry of Industry and Information Technology, People's Republic of China \\
\hline MOF & Ministry of Finance, People's Republic of China \\
\hline MOHURD & Ministry of Housing and Urban-Rural Development, People's Republic of China \\
\hline MOST & Ministry of Science and Technology, People's Republic of China \\
\hline MPS & Ministry of Public Security, People's Republic of China \\
\hline Mtoe & Million tons of oil equivalent \\
\hline MW & Megawatts \\
\hline NBSC & National Bureau of Statistics of China \\
\hline NDRC & National Development and Reform Commission, People's Republic of China \\
\hline NFRC & National Fenestration Rating Council, United States \\
\hline OECD & Organisation for Economic Co-operation and Development \\
\hline PIR & Polyisocyanurate \\
\hline PUR & Polyurethane \\
\hline $\mathrm{R} \& \mathrm{D}$ & Research \& Development \\
\hline SME & Small-to-Medium Enterprises \\
\hline toe & Tonne of oil equivalent \\
\hline
\end{tabular}


UNDP United Nations Development Programme

XPS Extruded Polystyrene 


\section{Table of Contents}

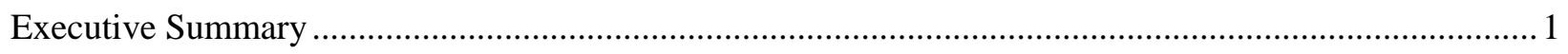

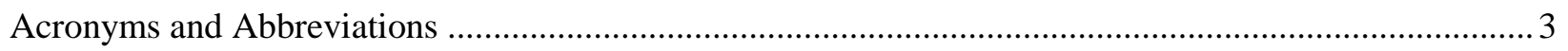

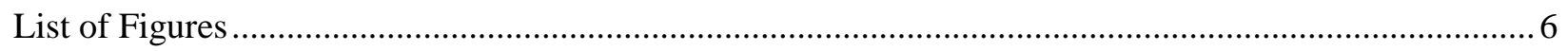

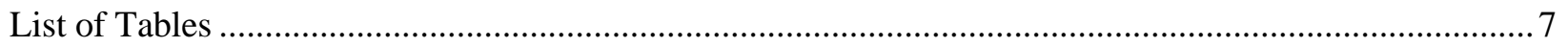

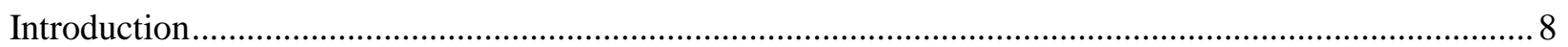

Energy Consumption Trends and Opportunities for Energy Efficiency ……........................................... 9

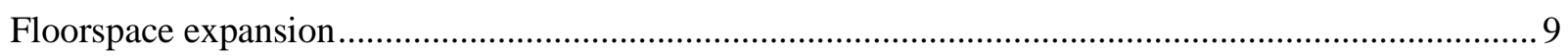

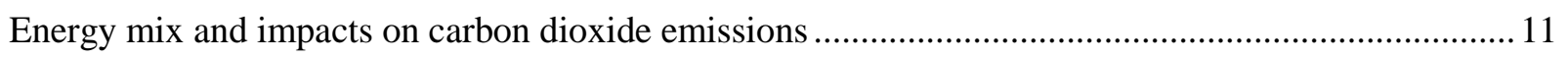

Building Energy Codes and Energy Efficiency Policies.................................................................... 14

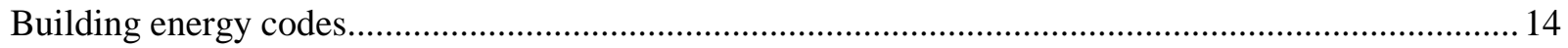

Beyond codes: green buildings and voluntary standards for advanced designs ................................. 16

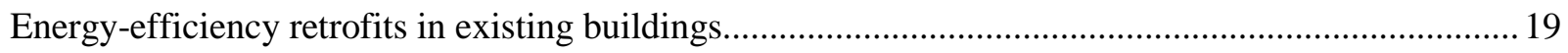

Most recent development and targets for building energy efficiency ................................................ 19

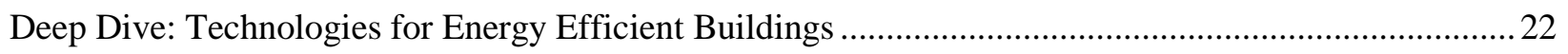

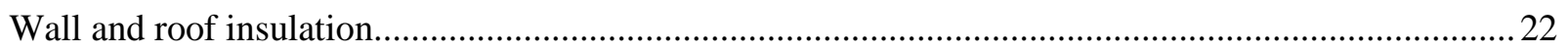

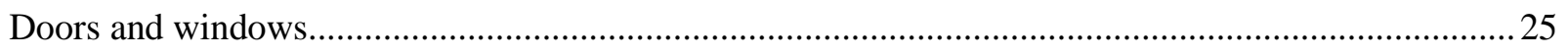

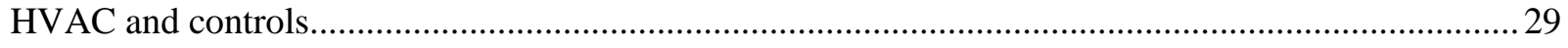

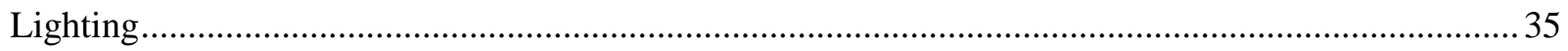

Existing Buildings: Energy Performance Contracts in Public Buildings.................................................. 40

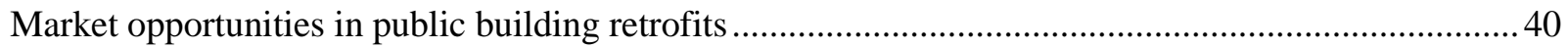

Energy performance contracts in public and large commercial buildings ......................................... 42

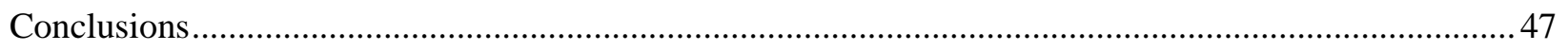

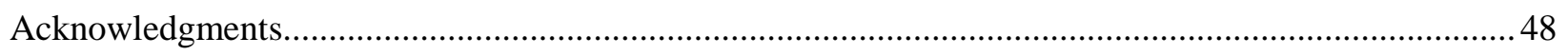

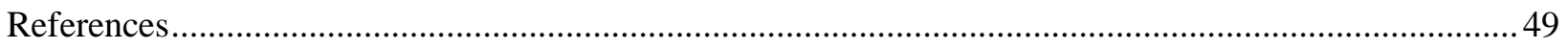

Appendix A U-Value of Building Envelope in Current Building Energy Codes for Residential Buildings

Appendix B Building Material and Product Database Used in Code Compliance in China ......................57

Appendix C Energy Efficiency Retrofit for China Construction Bank Headquarter (Shared-Savings) ..... 63

Appendix D Energy Efficiency Retrofit for Xijing Hospital in Xi’an City (Chauffage)............................ 65 


\section{List of Figures}

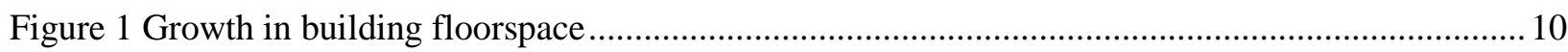

Figure 2 Growth of per capita floorspace in Chinese residential buildings .......................................... 10

Figure 3 International comparison of per capital residential (left) and commercial (right) floorspace in consideration of income (per capita GDP in purchasing power parity) .......................................... 11

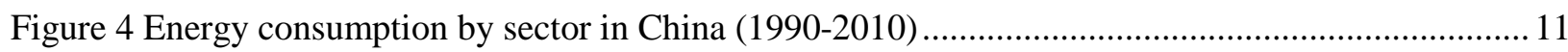

Figure 5 Fuel consumption (left) and energy services (right) for Chinese buildings................................ 12

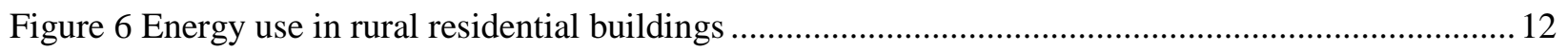

Figure 7 Energy use intensity of urban residential (left) and commercial buildings (right)..................... 13

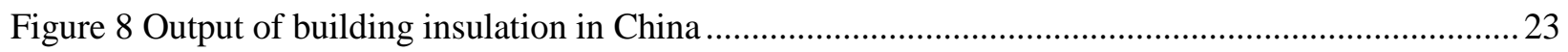

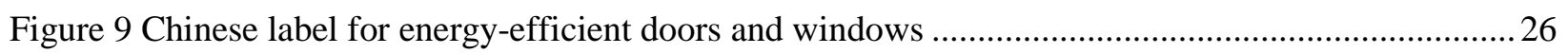

Figure 10 Market penetration rate of low-e glass in the world (2010) .................................................. 28

Figure 11 China’s HVAC equipment market (excluding district heating), 2008-2015 ........................... 29

Figure 12 District-heated housing area in urban China (2004-2011)...................................................... 31

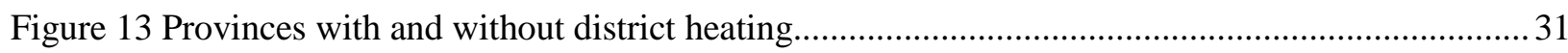

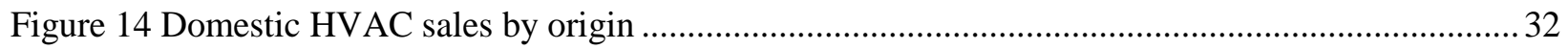

Figure 15 Equipment sales of the central air conditioner industry in China (2008-2012)........................ 33

Figure 16 Sales of building automation equipment in China.............................................................. 34

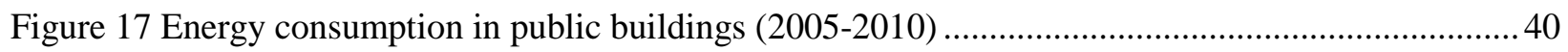

Figure 18 Fuel profile of public buildings (2010).............................................................................. 40

Figure 19 Energy performance contracting project type (left) and investment (right) ............................. 43

Figure 20 Technologies used by ESCOs in energy-efficiency retrofits of public and large commercial

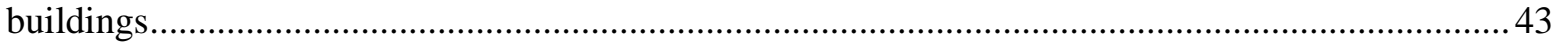

Figure 21 Registered capital of EMCA-member ESCOs (2009)........................................................... 44

Figure 22 Share of Chinese energy performance contracts by project (left, 2007-2009) and by investment

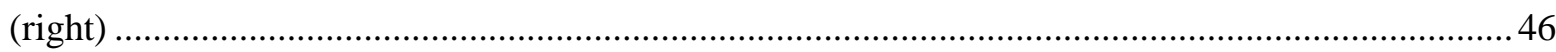




\section{List of Tables}

Table 1 Planned and completed energy efficiency retrofits in rural homes, 2009-2013........................... 13

Table 2 Development of building energy codes in China................................................................... 14

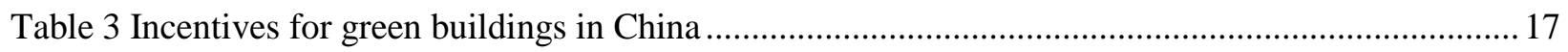

Table 4 Building energy efficiency goals and expected investment (2011-2015) ................................... 20

Table 5 Key specifications of different insulation materials ............................................................. 23

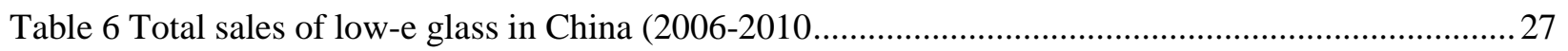

Table 7 Supply and demand forecast of low-e glass industry, 2011-2015 ........................................... 28

Table 8 EER requirements for room air conditioners (severe cold and cold regions) ............................... 30

Table 9 Roadmap of the incandescent phase-out policy in China ........................................................... 36

Table 10 Forecast of the Chinese lighting market (by products) …....................................................... 36

Table 11 Forecast of the Chinese lighting market (by segment in million USD) .................................... 37

Table 12 Programs improving energy efficiency in public buildings (2011-2015)................................ 41 


\section{Introduction}

China has experienced rapid economic growth in the past two decades with average, annual GDP growth of 10\% (World Bank, 2011). The unprecedented growth also drives expansion in the buildings sector. Building energy consumption in China increased by 40\% from 1990 to 2009, which made China, after the U.S., the second largest building energy consumer in the world (IEA, 2012a). Building energy use accounts for 28\% of China's total energy use in 2009 when traditional biomass is included. Underlying the growth of energy consumption in the Chinese buildings sector is population and economic growth, a continued expansion in building floorspace, and installation of energy-consuming devices. Over the last several decades, China has added 1.8-2.0 billion $\mathrm{m}^{2}$ annually, establishing the world's largest market for new construction. Total urban residential floorspace is 20.6 billion $\mathrm{m}^{2}$, rural residential floorspace is 24 billion $\mathrm{m}^{2}$, and commercial ${ }^{1}$ building floorspace is 14 billion $\mathrm{m}^{2}$, as of 2010 . Growth in building floorspace and associated energy use will likely continue at least for the next several decades, as the country undergoes rapid income and population growth (Eom et al., 2012; Evans et al., 2013; Li and Yao, 2009; Yu et al., 2014a).

To curb the growing building energy demand, the Chinese government has developed policies promoting building energy efficiency. The Chinese government has developed and implemented building energy codes since the 1980s with a particular focus on the improvement of envelope insulation (Huang and Deringer, 2007; Shui et al., 2009). There are currently three energy codes for residential buildings in four

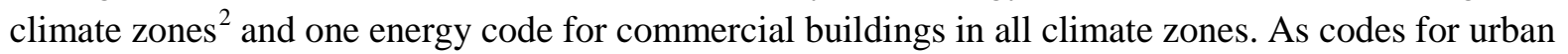
buildings are mandatory, all new urban residential ${ }^{3}$ and commercial buildings are currently required to comply with Chinese building energy codes in both design and construction stages. The Ministry of Housing and Urban-Rural Development (MOHURD) also issued an energy code for rural residential buildings, which went into effect in May 2013. Restricted by construction patterns of rural buildings, the rural code is currently voluntary; however, the Chinese government started to promote the rural code through incentive programs and aims to make it mandatory later.

Building energy codes set minimum legal requirements on building design and their compliance provisions during construction. Beyond energy codes, the Chinese government also developed a green building rating system, known as the Three-Star Building Rating System, under which buildings are rated one to three stars based on their energy performance and green features. The Three-Star Rating is similar to the Leadership in Energy and Environmental Design (LEED), but differs in an important way. It extends beyond the building design and rates the building after one year of operation. The Three-Star Rating is valid for three years and buildings need to be re-evaluated to retain the rating. The green building rating system is voluntary and the Chinese government provides incentives for green buildings.

\footnotetext{
${ }^{1}$ Commercial buildings in this report, if not specified, mean both private commercial buildings and public buildings. The definitions of public buildings in the U.S. and China are different. In China, the term public building often means commercial and public buildings. This report uses the U.S. meaning of public building, i.e., buildings owned or occupied by government or government-sponsored entities.

${ }^{2}$ Requirements for residential buildings in severe cold and cold climate regions are covered in one building energy code, and hot summer cold winter and hot summer warm winter regions have their respective building energy code for residential buildings.

${ }^{3}$ Different from residential buildings in the U.S., most residential buildings in urban areas in China are multi-family buildings.
} 
For example, MOHURD and the Ministry of Finance (MOF) provided 45 yuan $/ \mathrm{m}^{2}\left(\sim \$ 7.44 / \mathrm{m}^{2}\right)^{4}$ for TwoStar buildings and 80 yuan $/ \mathrm{m}^{2}\left(\sim 13.23 / \mathrm{m}^{2}\right)$ for Three-Star buildings in 2012 (MOF, 2012).

Along with the construction boom in the past two decades, there is also a growing stock of inefficient buildings due to lack of code compliance. The Chinese government started to emphasize code compliance since 2007 after the release of the Acceptance Code. Although the code compliance rate is high in major cities, code enforcement in small cities and towns are still poor. The Chinese government has seen great potential in energy savings through retrofitting existing buildings, which aims to bring energy performance of existing buildings to the level of code-compliant new buildings. The Chinese government provides technical support and financial incentives for building retrofits with a focus on two categories of buildings: residential buildings in northern China and public buildings across the country.

To further advance building energy efficiency and meet China's national goal of a 40-45\% reduction in carbon intensity by 2020 relative to 2005 levels, MOHURD and the National Development and Reform Commission (NDRC) issued a Green Building Action Plan in January 2013 and set targets for building energy efficiency in the near term (mostly until 2015). For new buildings, the Plan requires strict implementation of urban building energy codes and sets a goal of developing one billion $\mathrm{m}^{2}$ of green buildings which are rated one to three stars. For existing buildings, the Plan requires continuation of an existing program to retrofit residential buildings in the north and sets a goal of renovating 400 million $\mathrm{m}^{2}$ of floorspace by 2015; it also requires the retrofit of 50 million $\mathrm{m}^{2}$ of residential buildings in the Hot Summer Cold Winter region, the renovation of 120 million $\mathrm{m}^{2}$ of public buildings, and deep retrofit of 400,000 rural houses by 2015 (MOHURD, 2013b). These policies for new and existing buildings not only make the national and local governments focus on building energy efficiency, but also create a huge market for companies working on building energy efficiency.

This report assesses the impacts of China's policies on building energy efficiency. By examining the existing literature and interviewing stakeholders from the public, academic, and private sectors, the report seeks to offer in-depth insights of the opportunities and barriers for major market segments related to building energy efficiency. The report also discusses trends in building energy use, policies promoting building energy efficiency, and energy performance contracting for public building retrofits.

\section{Energy Consumption Trends and Opportunities for Energy Efficiency}

Building energy consumption in China has increased by $40 \%$ in the past two decades, driven by population and economic growth, an increase in building floorspace, and growing service demands. This section briefly discusses these drivers and changes in fuel use and building energy services.

\section{Floorspace expansion}

China's building floorspace has doubled from 1996 to 2011. In particular, floorspace of urban residential buildings has grown more than four times during this period. In contrast, the growth in rural building floorspace has slowed down as rural residents migrate to cities; however, floorspace of rural residential buildings is still significant with a total amount of around 24 billion $\mathrm{m}^{2}$ in 2011 , which is equivalent to total residential floorspace in the U.S. (NBSC, 2012; THUBERC, 2011). The importance of commercial

\footnotetext{
${ }^{4}$ The exchange rate used in this report is 1 USD $=6.05$ Chinese Yuan.
} 
buildings is also growing, and the stock of commercial buildings increased by more than double since 1996, although the stock is relatively small compared to residential buildings (Figure 1).

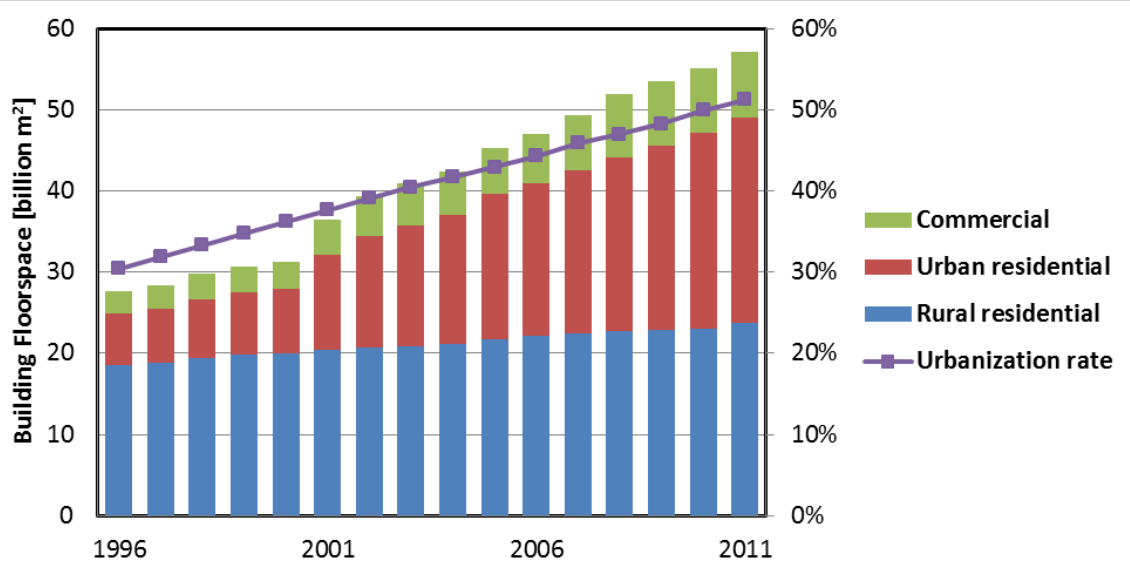

Figure 1 Growth in building floorspace

As income grows, per capita floorspace of residential buildings also increased dramatically (Figure 2) and the gap in per capita floorspace between rural and urban residential buildings has narrowed down. Per capita floorspace of urban residential buildings has tripled since 1985, rising from $10 \mathrm{~m}^{2} /$ person in 1985 to $31.6 \mathrm{~m}^{2}$ /person in 2011; per capita floorspace in rural areas also increased dramatically, from 14.7 $\mathrm{m}^{2} /$ person in 1985 to $34.1 \mathrm{~m}^{2} /$ person in 2011 (NBSC, 2012). However, per capita residential floorspace in China is still lower than the current level of $38-53 \mathrm{~m}^{2} /$ person in most OECD countries (except the U.S. and Canada). Per capita floorspace in residential buildings is expected to continue increase towards the end of the century and reach the current level of most OECD countries, but not the U.S. (Figure 3).

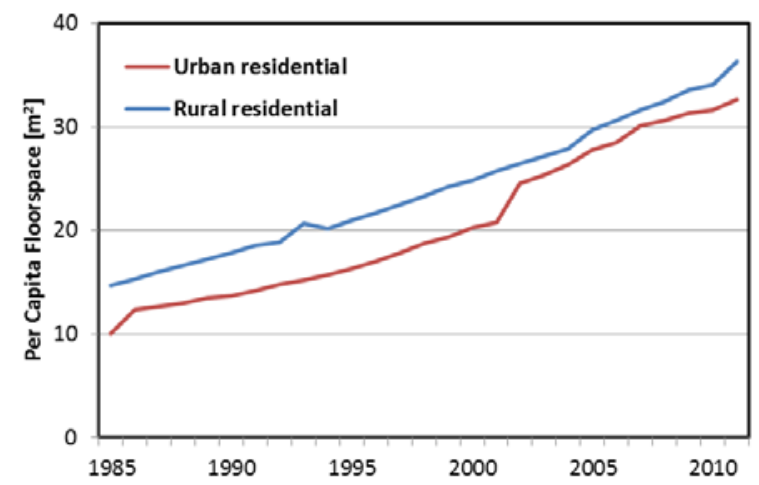

Figure 2 Growth of per capita floorspace in Chinese residential buildings

Per capita floorspace of commercial buildings is also growing. There is empirical evidence showing the growth of commercial buildings is associated with GDP growth (Figure 3). Currently, per capita as well as total floorspace of commercial buildings in China are low and will grow steadily in the future; however, at the per capita level, it still will be lower than the current level in most OECD countries (Evans et al., 2013; Yu et al., 2014b). 

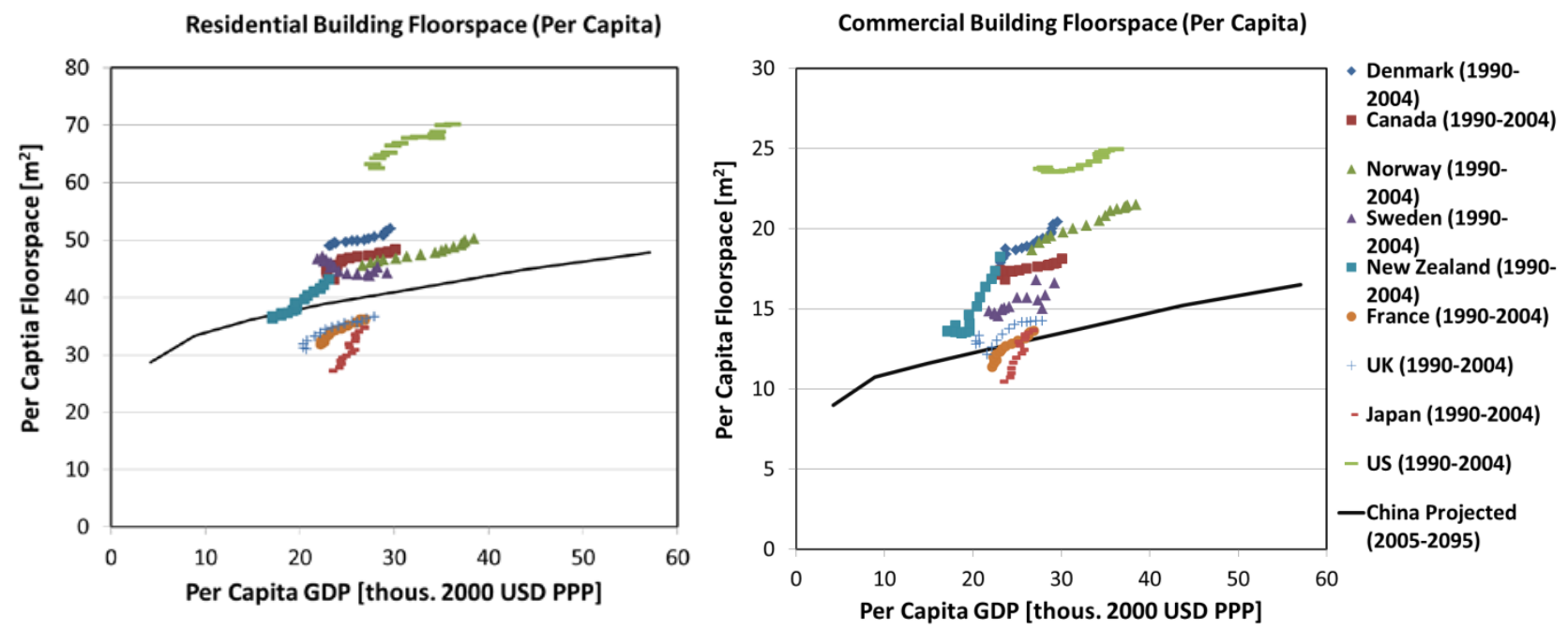

Figure 3 International comparison of per capital residential (left) and commercial (right) floorspace in consideration of income (per capita GDP in purchasing power parity)

\section{Energy mix and impacts on carbon dioxide emissions}

Buildings account for $28 \%$ of all energy use in China (Figure 4). The share is low in comparison to OECD countries, where buildings consume more than a third of the country's total energy use (IEA, 2012b). As China is transforming from a manufacturing-based economy to a balanced economic structure with more service-based sectors, the share of building energy use may continue to rise relative to industrial energy use, and China's building energy use is expected to increase by 40\% from 2009 to 2030, which will make it the largest building energy consumer in the world (IEA, 2011).

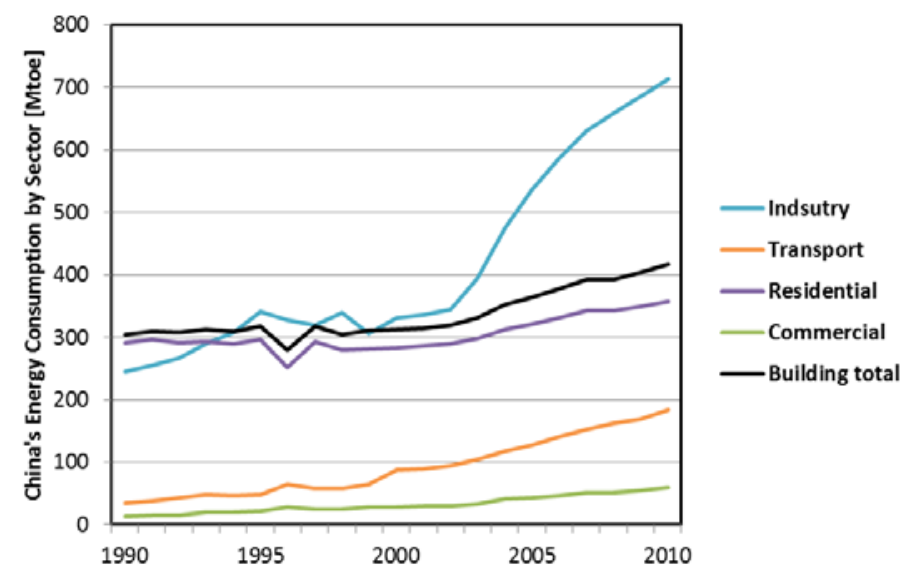

Figure 4 Energy consumption by sector in China (1990-2010)

Overall growth in the Chinese buildings sector, despite the government's policies on building energy efficiency, has driven an increase in energy consumption. Traditional biomass such as wood and crop stalks, because of its low energy conversion efficiency, has contributed to a significant share of China's total building energy use. $\mathrm{Coal}^{5}$ and electricity are currently the second and third largest energy sources for buildings. However, as building consumption continues to grow, the share of electricity will

\footnotetext{
${ }^{5}$ Energy consumption discussed in this report is final energy consumption directly used in buildings.
} 
dramatically increase and, by end of the century, the rate of electrification will be about $60 \%$. Underlying the trend of fast electrification is fuel substitution and the growth in appliances, lighting, and air conditioning. Heating energy demand will still be significant in the near term and then decline as a result of climate change and efficiency improvements (Figure 5).
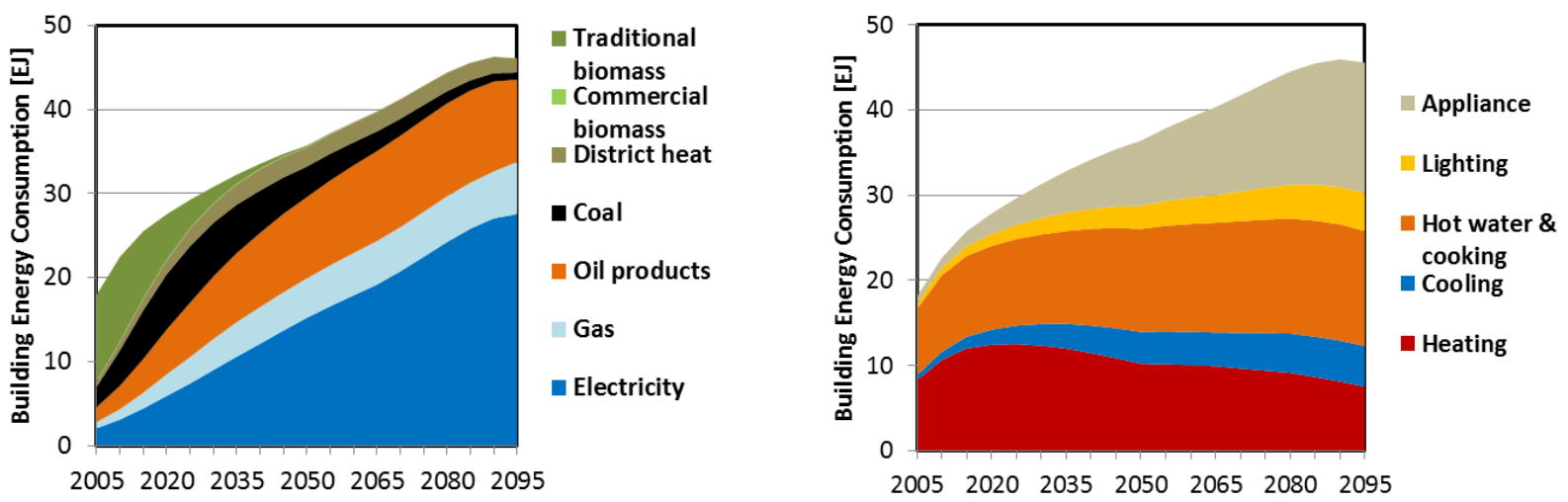

Figure 5 Fuel consumption (left) and energy services (right) for Chinese buildings

As shown in Figure 5, traditional biomass contributes to a great share of China's building energy use and it is mostly used in rural houses. However, with income growth, energy profiles in rural household evolve and traditional biomass will be gradually substituted by commercial fuels. Fuel substitution happens at two stages. In the next two decades, the decline in traditional biomass will be accompanied by the increasing use of coal in all regions, which may lead to high emissions and air pollution problems. The second stage of fuel substitution happens after 2030. As income further increases, rural households will reduce the use of coal and switch to cleaner fuels such as electricity and gas in the second half of the century (Figure 6). The transition of energy systems in rural areas also helps grow a market for energy efficient technologies and products.

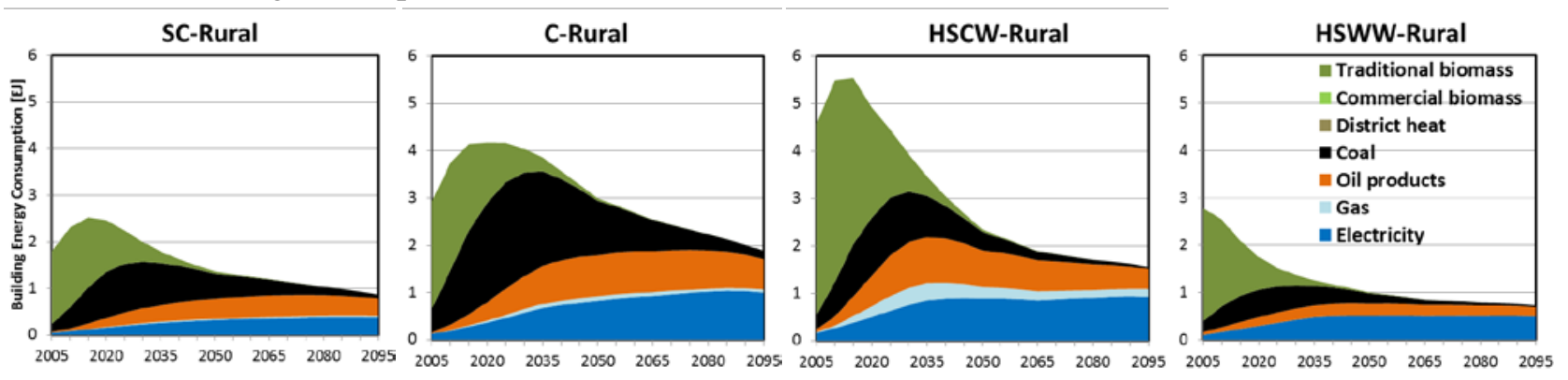

Figure 6 Energy use in rural residential buildings

Note: SC, C, HSCW and HSWW are climate regions in China; they stand for Severe Cold, Cold, Hot Summer Cold Winter, and Hot Summer Warm Winter, respectively.

Most rural homes do not have insulation and only have limited heating and cooling systems and appliances. The Chinese government started programs in recent years to improve thermal comfort as well as efficiency of rural houses. The Ministry of Agriculture and MOF have invested over 61 billion yuan ( $\sim 10$ billion) in the construction of household biogas systems since 2003, and the number of biogas plants installed has doubled since 2000 (Chen et al., 2010). MOHURD started to promote deep retrofits or construction in rural homes since 2009 and provided additional subsidies to rural homes with energy- 
efficient measures. The subsidy amount was 6,000 yuan/household ( $\$ 992 /$ household) for reconstruction and 2,000 yuan/household ( $\sim 331 /$ household) for installation of energy-efficient technologies during 2009-2011, and then increased to 7,500 yuan/household ( $\sim$ 1240/household) for reconstruction and 2,500 yuan/household ( $\sim 413 /$ household) for installation of energy-efficient technologies during 2012-2013. (MOHURD et al., 2012). Some provinces also provided additional subsidies to energy efficiency retrofits in rural homes. The program has retrofitted around 540,000 rural homes in the past five years (Table 1). MOHURD plans to conduct deep retrofits in additional 400,000 rural households to achieve code compliance by 2015. MOHURD is also considering a more systematic approach to implement the new rural energy code (MOHURD, 2013a).

Table 1 Planned and completed energy efficiency retrofits in rural homes, 2009-2013

\begin{tabular}{|l|c|c|c|c|c|}
\hline \multicolumn{1}{|c|}{ Year } & $\mathbf{2 0 0 9}$ & $\mathbf{2 0 1 0}$ & $\mathbf{2 0 1 1}$ & $\mathbf{2 0 1 2}$ & $\mathbf{2 0 1 3}$ \\
\hline Planned & 15,000 & 28,000 & 84,000 & 411,000 & 140,000 \\
\hline Completed & 39,530 & 58,159 & 207,394 & 130,800 & - \\
\hline
\end{tabular}

The profile of energy use in urban residential and commercial buildings is different from that of rural buildings. Along with the growth of aggregate energy use, energy use intensity (EUI) of Chinese buildings will also rise. In urban residential buildings, EUI will grow rapidly in the next decade and then the growth slows down, but it will still be lower than the current level of most OECD countries. In commercial buildings, EUI will keep rising and reach the current level of most OECD countries. It is worth noting that EUI in most developed countries has declined as GDP grew, while EUI of Chinese urban residential and commercial buildings keeps growing in most regions (Figure 7). In fact, studies have shown that compared to the business-as-usual case, energy codes could help reduce China's building energy use and $\mathrm{CO}_{2}$ emissions by $14-22 \%$, depending on the stringency and coverage of codes (Yu et al., 2014a). The Chinese government has initiated programs and incentives promoting energy efficiency for new and existing buildings. The next section discusses Chinese policies on building energy efficiency and how these policies affect the market and energy use in China.
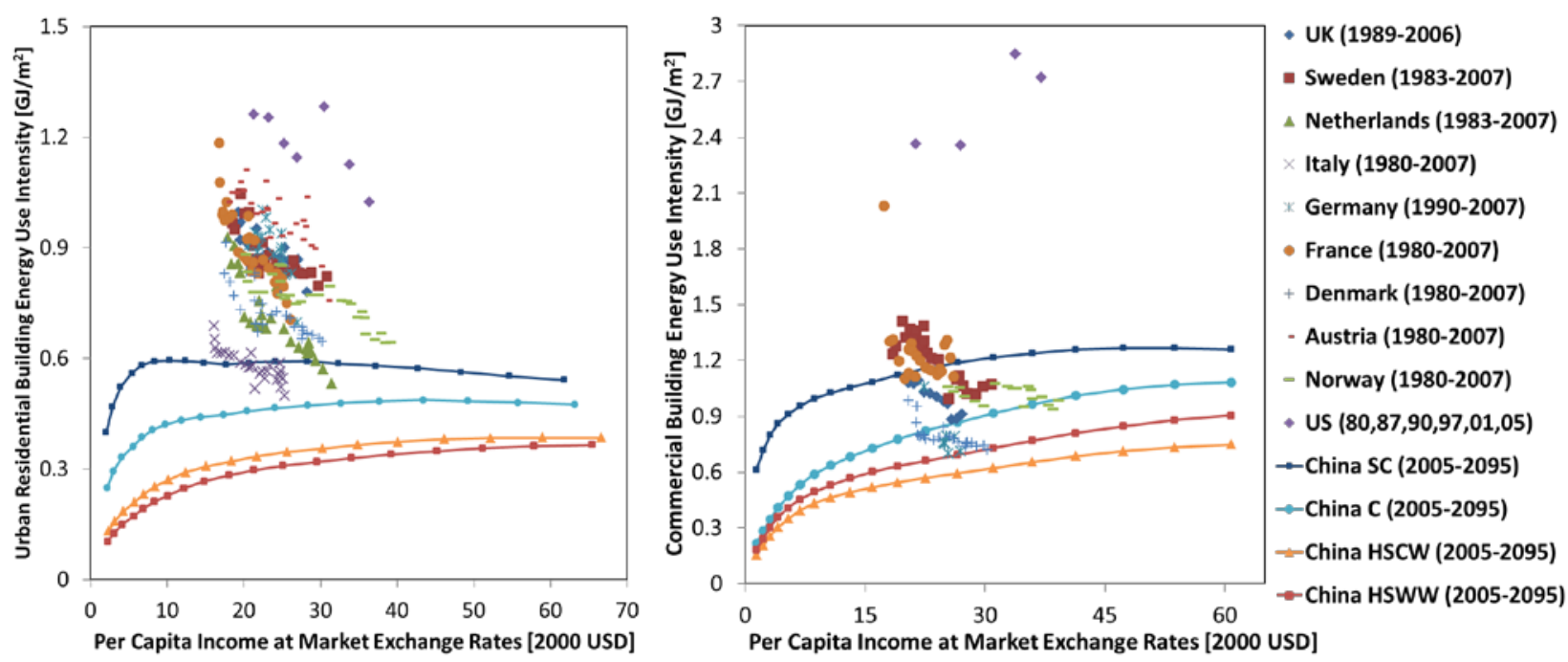

Figure 7 Energy use intensity of urban residential (left) and commercial buildings (right)

Note: The projection uses the business-as-usual scenario. 


\section{Building Energy Codes and Energy Efficiency Policies}

China has hybrid policies addressing both new and existing buildings. Currently, there are mandatory building energy codes for urban residential and commercial buildings, a voluntary energy code for rural residential buildings, green building rating system, programs promoting energy-efficiency retrofits in existing buildings, and incentives and policies encouraging improvement in building energy efficiency. These policies and programs together helped improve energy efficiency of Chinese buildings and expand the market for energy efficient products. In addition, the Chinese government sets ambitious goals to improve building energy efficiency during the $12^{\text {th }}$ Five-Year Plan (FYP) period (2011-2015), which will further drive the demand for energy efficient products (see details in Table 4, pages 18-19). This section briefly discusses existing policies related to building energy efficiency in China and lays out quantitative targets for improving energy performance of Chinese buildings.

\section{Building energy codes}

Building energy codes in China set minimum energy efficiency requirements for different building components (e.g. envelope, HVAC, and power system). Code development in China has gone through three stages (Table 2). The first stage from1986 to 2005 was the initiation of China's first national building code. The former National Energy Committee initiated research for the Design Standard for Energy Efficiency of Residential Buildings (JGJ 26-86). MOHURD used it as the basis to issue the code in 1986. The Design Standard required a 30\% cut in energy consumption for space heating compared to reference buildings from 1980 . The code was implemented by local authorities, and it is estimated there were 100,000 $\mathrm{m}^{2}$ of code-compliant floorspace during 1986-1991. Deployment of energy efficient technologies was slow during this period.

Table 2 Development of building energy codes in China

\begin{tabular}{|c|c|c|c|}
\hline Building Type & \multicolumn{3}{|c|}{ Climate Region } \\
\hline & SC & HSCW & HSWW \\
\hline $\begin{array}{l}\text { Urban } \\
\text { Residential }\end{array}$ & $\begin{array}{l}\text { Design Standard for } \\
\text { Energy Efficiency of } \\
\text { Residential Buildings in } \\
\text { Severe Cold and Cold } \\
\text { Zones (JGJ 26); Years of } \\
\text { Enactment: 1986, 1995, } \\
2010 \text { (Mandatory) }\end{array}$ & $\begin{array}{l}\text { Design Standard for } \\
\text { Energy Efficiency of } \\
\text { Residential Buildings in } \\
\text { Hot Summer and Cold } \\
\text { Winter Zone (JGJ 134); } \\
\text { Years of Enactment: } \\
\text { 2001, } 2010 \text { (Mandatory) }\end{array}$ & $\begin{array}{l}\text { Design Standard for } \\
\text { Energy Efficiency of } \\
\text { Residential Buildings in } \\
\text { Hot Summer and Warm } \\
\text { Winter Zone (JGJ 95); } \\
\text { Years of Enactment: 2003, } \\
2012 \text { (Mandatory) }\end{array}$ \\
\hline Commercial & \multicolumn{3}{|c|}{$\begin{array}{l}\text { Design Standard for Energy Efficiency of Public Buildings (GB 50189); Years of } \\
\text { Enactment: 1993, } 2005 \text { (Mandatory) }\end{array}$} \\
\hline Rural Residential & \multicolumn{3}{|c|}{$\begin{array}{l}\text { Design Standard for Energy Efficiency of Rural Residential Buildings (GB 50824); } \\
\text { Year of Enactment: } 2012 \text { (Voluntary) }\end{array}$} \\
\hline
\end{tabular}

The second stage (1995-2005) was marked by the new Design Standard for Energy Efficiency of Residential Buildings in 1995 (JGJ 26-95). Compared to the 1986 version, the 1995 energy code for residential buildings had higher energy-efficiency requirements and aimed to cut energy use by 50\% comparing with 1980 reference buildings. The Chinese government also expanded the coverage of building energy codes. While the 1986 and 1995 codes only applied to buildings in the north with heating, 
energy codes for the rest climate zones (except the temperate zone) were issued during the second stage of code development. MOHURD issued the Design Standard for Energy Efficiency of Residential Buildings in Hot Summer and Cold Winter Zone (JGJ 134-2001) and Design Standard for Energy Efficiency of Residential Buildings in Hot Summer and Warm Winter Zone (JGJ 75-2003) in 2001 and 2003, respectively. MOHURD, for the first time, also issued a national building code for commercial buildings, known as GB50189-2005. Another major trend was the enactment of technical standard for home appliances. The Code for Design of Heating Ventilation and Air Conditioning (GB 50019-2003) and the Standard for Lighting Design of Buildings (GB 50034-2004) regulated two major sources of energy consumption in the buildings sector. The Chinese government also issued laws to ensure the implementation of building codes. The Provisions on the Administration of Energy Conservation for Civil Buildings of 2005 put emphasis on energy efficient design for new buildings. During the second stage, the compliance rate for building energy codes reached 53\% at the design level and 20\% at the construction level.

China entered the third stage (2006-present) of building code development and implementation since 2006. During this stage, the Chinese government has improved the stringency of building energy codes, strengthened code compliance checks, and developed incentives to promote the deployment of energy efficient products.

The Code for Acceptance of Energy Efficient Building Construction (GB50411-2007) and the Standard for Energy Efficiency Test of Residential Buildings (JGJ/T 132-2009) helped strengthen the promotion of energy efficient buildings by rigorous test and acceptance checks. Technical standards such as Technical Code for Ground-Source Heat Pump System (GB 50366-2005) and Technical Code for Solar Heating System (GB 50495-2009) regulate energy efficiency of equipment and appliances. The compliance rate has increased dramatically during the third stage. At the design stage, it has increased from 53\% in 2005 to $99 \%$ in 2010 , and the compliance rate at the construction stage has almost quadrupled during the same period and reached $95.4 \%$ in 2010. Although China's high compliance rate is associated with their survey methodologies and statistical methods, it is still important to note that the Chinese government has put significant efforts on energy code development and implementation. The stringency of energy codes have been improved in the past two decades (see Appendix A for the current requirements of U-values for walls and windows). The Chinese government has enhanced the requirements of energy savings from $30 \%$ to $50 \%$ and then to the current $65 \%$, compared to the reference buildings in 1980 (which did not have any energy saving measures). The new energy code for commercial buildings, which is expected to be released in 2014, sets new energy saving targets and aims to improve energy efficiency by 30\% compared to its last version released in 2005. The mandatory energy codes set the minimum energy-efficiency requirements for Chinese buildings and drive the market at a large scale. As codes improved, the demand for efficient products increased. For example, northern China has widely upgraded its windows from single-pane to double-pane, and triple-pane in some cities, which creates a market that did not exist before.

Meanwhile, policy incentives together with new laws on energy conservation have laid the foundation of prospective policies on building energy efficiency ${ }^{6}$. Both the Building Energy Conservation Plan in

\footnotetext{
${ }^{6}$ At the third stage, several laws have been enacted or revisited to accommodate the energy conservation plan nationwide, including Medium- and Long-Term Plan for Conserving Energy Resources, Energy Conservation Law, Regulation on Energy Conservation in Civil Buildings, and Renewable Energy Law.
} 
Twelfth Five-Year Period and the Green Building Action Plan require detailed and quantitative goals for energy efficient buildings, reducing 81.2 Mtoe of energy consumption by the end of 2015 .

\section{Beyond codes: green buildings and voluntary standards for advanced designs}

Beyond mandatory building codes in China, voluntary standards such as green building ratings are widely accepted in big cities and population centers. The Three-Star rating system, introduced in 2006, is a credit-based, voluntary rating system for green buildings. It evaluates buildings with a variety of prerequisites (called "control items" in the Chinese system) and credits (called "general items" in the Chinese system) in six categories: land savings and outdoor environment, energy savings, water savings, materials savings, indoor environmental quality, and operations and management. A seventh category called "preference items" contains strategies that are cutting-edge and harder to implement, such as brownfield redevelopment and more than $10 \%$ on-site renewable power generation.

Recent policies have promoted the Three-Star system to accommodate the long-term energy reduction goal in the buildings sector. For example, MOF issued the Implementation Guideline of Green Building Development (also known as Decree No. 167) in 2012 and provided subsidies for certified green building projects. Driven by the national plan, local governments also provide subsidies for green buildings (Table 3). Some local governments even make it a mandatory requirement for future development ${ }^{7}$ (Geng, 2013).

Another major green building program in China is LEED. LEED, developed by the US Green Building Council in 2000, also uses a credit-based system to evaluate buildings in terms of site selection, water efficiency, energy, materials and resources, indoor environmental quality, and design innovation. Although both systems have a lot in common, they diverge in their ratings and review processes.

Unlike the Three-Star system, LEED does not require builders to meet minimum requirements in every category, but instead allows builders to achieve a LEED rating by meeting a minimum number of aggregate credits. LEED uses different rating systems for new construction, existing buildings, schools, and neighborhood development projects.

Moreover, LEED for Core and Shell system allows developers to submit their design and achieve "precertification", which they can then market to prospective tenants before the building is built. Compared to the strong requirement of the Three-Star system that a rating can only be awarded after one year of property operation, LEED provides opportunities for developers to capture some of the benefits of going green by getting higher rents and faster occupancy, which ultimately drives more developers to build green and create greater market for energy efficient materials. After eight years of development, China now is the third largest market for LEED in the world and has over 1,500 registered and certified LEED projects, accounting for over 67 million $\mathrm{m}^{2}$ in China (Crea, 2013).

\footnotetext{
${ }^{7}$ Beijing government requires every new construction after June 1, 2013 to conform to the Green Building Rating Program. Other governments such as Xiamen, Wuhan, Shenzhen, and Jiangsu have similar plans in the future.
} 
Table 3 Incentives for green buildings in China

\begin{tabular}{|c|c|}
\hline Regions & Incentives \\
\hline \multicolumn{2}{|c|}{ National Incentives } \\
\hline Nationwide & $\begin{array}{l}\text { Subsidy: two-star: } 45 \text { yuan } / \mathrm{m}^{2} \text {; three-star: } 80 \text { yuan } / \mathrm{m}^{2} \\
\text { Eco-city incentive: criteria for a city to obtain the } 50 \text { million yuan green eco-city subsidy include: } 1 \text { ) all new constructions should be } \\
\text { certified as one-star or above; } 2 \text { ) more than } 30 \% \text { of new constructions should be two-star or above; 3) the city constructs more than } 2 \text { million } \\
\mathrm{m}^{2} \text { of new green buildings within two years. }\end{array}$ \\
\hline \multicolumn{2}{|c|}{ Additional Provincial Incentives } \\
\hline Shaanxi & $\begin{array}{l}\text { Subsidy: one-star: } 10 \text { yuan } / \mathrm{m}^{2} \text {; two-star: } 15 \text { yuan } / \mathrm{m}^{2} \text {; three-star: } 20 \text { yuan } / \mathrm{m}^{2} \\
\text { Eco-district incentive: criteria for a district to obtain } 1 \text { million yuan green eco-district subsidy include: (1) all new constructions should be } \\
\text { certified as one-star or above; (2) more than } 30 \% \text { of the new constructions should be two-star or above; (3) the district constructs } 1-2 \text { million } \\
\mathrm{m}^{2} \text { of new green buildings within two years. }\end{array}$ \\
\hline Jiangsu & Subsidy: one-star and above design certification: 15 yuan $/ \mathrm{m}^{2} ;$ operational certification: 10 yuan $/ \mathrm{m}^{2}$ \\
\hline Guangdong & Subsidy: two-star: 25 yuan/m² (maximum: 1.5 million yuan per project); three-star: 45 yuan/m² (maximum: 2 million yuan per project) \\
\hline Fujian & $\begin{array}{l}\text { Subsidy: certified green buildings (one to three stars): } 10 \text { yuan } / \mathrm{m}^{2} \\
\text { Floor to area ratio reward: one-star: } 1 \% \text {; two-star: } 2 \% \text {; three-star: } 3 \% \\
\text { Low-interest loan: housing loan for consumer: } 0.5 \% \text { lower than the standard interest rate; housing loan for real estate developer: } 1 \% \text { lower } \\
\text { than the standard interest rate }\end{array}$ \\
\hline $\begin{array}{l}\text { Inner } \\
\text { Mongolia }\end{array}$ & Municipal infrastructure charge (150 yuan/m²) exemption: one-star: 30\%; two-star: 70\%; three-star: 100\% \\
\hline Qinghai & Municipal infrastructure charge rebate: one-star: 30\%; two-star: 50\%; three-star: 70\% \\
\hline Hainan & Municipal infrastructure charge rebate: two-star: 20\%; three-star: $40 \%$ \\
\hline \multicolumn{2}{|c|}{ Additional Incentives Provided by Cities } \\
\hline Beijing & $\begin{array}{l}\text { Subsidy: two-star: } 22.5 \text { yuan } / \mathrm{m}^{2} \text {; three-star: } 40 \text { yuan } / \mathrm{m}^{2} \\
\text { Fee exemption: green building certification fee exemption }\end{array}$ \\
\hline Shanghai & $\begin{array}{l}\text { Subsidy: two-star and three-star: up to } 60 \mathrm{yuan} / \mathrm{m}^{2} \text { (maximum: } 6 \text { million yuan for normal projects and } 10 \text { million yuan for low-income } \\
\text { housing projects). The subsidy applies to: } 1 \text { ) two-star residential buildings of } 25,000 \mathrm{~m}^{2} \text { and above; } 2 \text { ) three-star residential buildings of } \\
10,000 \mathrm{~m}^{2} \text { and above; } 3 \text { ) two-star public buildings of } 10,000 \mathrm{~m}^{2} \text { and above; or } 4 \text { ) three-star buildings of } 5,000 \mathrm{~m}^{2} \text { and above. }\end{array}$ \\
\hline Nanjing & Floor to area ratio reward: $0.1-0.2$ floor to area ratio rewards for certified green buildings larger than $10,000 \mathrm{~m}^{2}$ \\
\hline
\end{tabular}




\begin{tabular}{|l|l|}
\hline Xi'an & $\begin{array}{l}\text { Subsidy: one-star: } 5 \text { yuan/m } \mathrm{m}^{2} \text {; two-star: } 10 \text { yuan } / \mathrm{m}^{2} \text {; three-star: } 20 \text { yuan } / \mathrm{m}^{2} \\
\text { Eco-district incentive: criteria for a district to obtain } 500,000 \text { yuan green eco-district subsidy include: (1) all new constructions should be } \\
\text { certified as one-star or above; (2) more than } 30 \% \text { of the new constructions should be two-star or above; (3) the district constructs more than } \\
2 \text { million } \mathrm{m}^{2} \text { of new green buildings within two years. }\end{array}$ \\
\hline Wuhan & $\begin{array}{l}\text { Subsidy: available for application for two and three-star buildings } \\
\text { Other reward: } 50 \% \text { reduction in new wall material research charge and cement research charge }\end{array}$ \\
\hline Qingdao & $\begin{array}{l}\text { Subsidy: one-star: } 30 \text { yuan } / \mathrm{m}^{2} \text { for public buildings and } 20 \text { yuan } / \mathrm{m}^{2} \text { for residential buildings (maximum: } 600,000 \text { yuan per project); two-star: } \\
40 \text { yuan/ } \mathrm{m}^{2} \text { for public buildings and } 30 \text { yuan } / \mathrm{m}^{2} \text { for residential buildings (maximum: } 1 \text { million yuan per project); three-star: } 50 \text { yuan/ } \mathrm{m}^{2} \text { for } \\
\text { public buildings and } 40 \text { yuan } / \mathrm{m}^{2} \text { for residential buildings (maximum: } 1.5 \text { million yuan per project) }\end{array}$ \\
\hline Tianjin & Cash reward: 30,000 yuan reward for green building design certification and 20,000 yuan reward for green building operation certification \\
\hline Kunming & Construction costs rebate: $20 \%$ rebate in construction costs \\
\hline Shenzhen & $\begin{array}{l}\text { Floor to area ratio reward: available for application for "two-star and three-star green buildings" } \\
\text { Fee exemption: green building certification Fee exemption }\end{array}$ \\
\hline
\end{tabular}

Note:

1. All direct subsidies, excluding those in Jiangsu Province and Qingdao City, should be considered subsidies for buildings that obtain green building operation certifications.

2. Subsidies in Jiangsu Province and Qingdao City are awarded after buildings obtain green building design certifications.

3. In Shaanxi and Guangdong Provinces, the provincial subsidies require additional government-assigned third party operation evaluation. 


\section{Energy-efficiency retrofits in existing buildings}

Energy-efficiency retrofits in existing buildings in China can be traced back to several small-scale pilot projects in the 1990s. However, lacking a systematic plan from the government, theses attempts were not popularized (Li, 2009). In 2000, MOHURD issued the Technical Specifications for Energy Efficiency Retrofits in Existing Buildings (JGJ129-2000) as an industrial standard. It illustrates the principles and contents of retrofits, including wall insulation, air tightness of doors and windows, and heating systems. However, as a technical standard, it was non-binding without either mandates or incentives attached to it (Zhao and Lou, 2013).

The large-scale building retrofits started in late 2000s. To achieve the $11^{\text {th }}$ FYP's goal of a $20 \%$ reduction in energy consumption per GDP, the State Council issued "Information Related to Comprehensive Energy Saving and Emission Reduction” in 2007, which specified the target of retrofitting 150 million $\mathrm{m}^{2}$ of floorspace in the northern heating zone by the end of 2011. This document initiated large-scale retrofits in 15 northern provinces.

In 2011, the Chinese government strengthened the emphasis on retrofits of government and other public buildings by issuing "Notification on Further Implementation of Energy-efficiency Retrofits in Public Buildings” (MOF and MOHURD, 2011). It requires a 10\% reduction of energy consumption per $\mathrm{m}^{2}$ for public buildings and $15 \%$ reduction for large public buildings with over $20,000 \mathrm{~m}^{2}$ of floor area by the end of 2015.

Based on the achievement over the $11^{\text {th }}$ FYP period, the Green Building Action Plan released in 2013 outlines that more than 0.4 billion $\mathrm{m}^{2}$ out of 3.5 billion $\mathrm{m}^{2}$ houses in the north should be retrofitted to the level of current building energy code by the end of 2015, and all eligible buildings in the northern heating zone should be retrofitted by the end of 2020. Local governments also share these ambitious goals. For example, the Beijing Government set the goal of retrofitting the floorspace of 150 million $\mathrm{m}^{2}$ from 2011 to 2015, which is equivalent to the total floor areas retrofitted in northern China during 2006-2010 (Beijing Municipal Commission of City Administration and Environment, 2011; MOHURD, 2012).

\section{Most recent development and targets for building energy efficiency}

In addition to existing policies and regulations, the Chinese government also set ambitious goals for building energy efficiency for the $12^{\text {th }}$ FYP period (Table 4). Compared to the $11^{\text {th }}$ FYP period, the $12^{\text {th }}$ FYP proposes more stringent standards for new buildings, expands the coverage of energy efficiency programs, and aims for savings from more sectors, including rural houses. This will also create market for energy efficient products. For example, to achieve the targets of the $11^{\text {th }} \mathrm{FYP}$, the central government has invested 15.2 billion yuan ( $\sim 2.5$ billion) in energy efficient retrofits and renewable energy installations, and the provincial and city governments have arranged 6.9 billion yuan ( $\$ 1.14$ billion) and 6.5 billion yuan ( $\sim 1.07$ billion), respectively, in financing through new building energy efficiency funds. Given the more ambitious goals set by the government, investment in building energy efficiency will likely increase in the near term.

Energy codes, green building ratings, building retrofit programs, and China's national plan all promote building energy efficiency and help create a favorable environment for the deployment of energy efficient materials and products. The next two sections will discuss the implication of these policies for different building components and provide insights for the impacts on the market. 
Table 4 Building energy efficiency goals and expected investment (2011-2015)

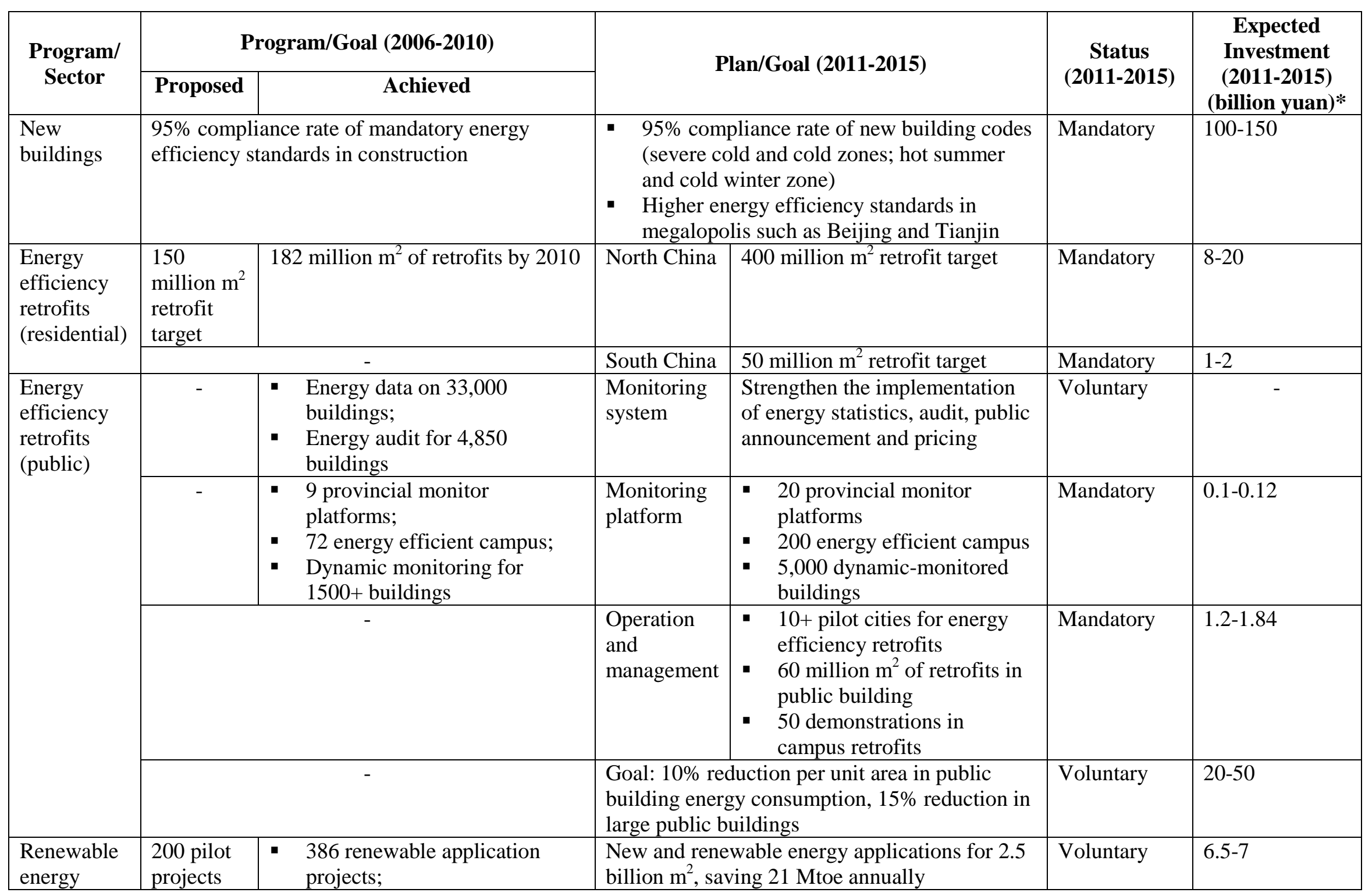




\begin{tabular}{|c|c|c|c|c|c|}
\hline application & & $\begin{array}{l}\text { - } 210 \text { solar building application; } \\
47 \text { pilot cities and } 98 \text { pilot } \\
\text { counties }\end{array}$ & & & \\
\hline $\begin{array}{l}\text { Green } \\
\text { buildings }\end{array}$ & $\begin{array}{l}30 \text { pilot } \\
\text { projects }\end{array}$ & 217 projects by 2010 & $\begin{array}{l}\text { - } 800 \text { million m2 new green buildings } \\
\text { - } 20 \% \text { new constructions in } 2015 \text { should meet } \\
\text { the green building requirements }\end{array}$ & Voluntary & $48-80$ \\
\hline $\begin{array}{l}\text { Rural } \\
\text { buildings }\end{array}$ & - & $\begin{array}{l}\text { - New energy efficient buildings } \\
\text { for 13,851 households; } \\
\text { - Energy efficiency retrofits for } \\
\text { 342,401 households; } \\
\text { - New construction for } 600 \\
\text { public solar bathroom } \\
\end{array}$ & $\begin{array}{l}\text { Energy efficiency retrofits for } 400,000 \\
\text { households }\end{array}$ & Voluntary & $8-12$ \\
\hline $\begin{array}{l}\text { Energy } \\
\text { efficient } \\
\text { building } \\
\text { materials }\end{array}$ & - & $\begin{array}{l}\text { - } 400 \text { billion units of energy } \\
\text { efficient bricks production; } \\
\text { - } 360 \text { billion units of energy } \\
\text { efficient bricks application; } \\
\text { - } 55 \% \text { production of wall } \\
\text { materials should be new wall } \\
\text { materials; } \\
\text { - } 70 \% \text { applications of wall } \\
\text { materials should be new wall } \\
\text { materials }\end{array}$ & $\begin{array}{l}\text { - } 65 \% \text { production of wall materials should } \\
\text { be new wall materials } \\
\text { - } 75 \% \text { applications of wall materials should } \\
\text { be new wall materials }\end{array}$ & Voluntary & . \\
\hline $\begin{array}{l}\text { Policies and } \\
\text { mechanisms }\end{array}$ & & - & $\begin{array}{l}\text { Based on "Regulation on Energy } \\
\text { Conservation in Civil Buildings" and } \\
\text { "Energy Conservation Law", establish the } \\
\text { regulation system for building energy } \\
\text { efficiency with central and local policies } \\
\text { and regulations } \\
\text { - Clarify the responsibilities for provincial, } \\
\text { municipal and county level governments } \\
\text { - Amplify the energy efficiency standards } \\
\text { system, implement building energy } \\
\text { statistics, monitoring and evaluation system }\end{array}$ & Voluntary & \\
\hline
\end{tabular}

Source: (CITIC Securities, 2013a; MOHURD, 2011b; Orient Securities, 2013).

*This is based on estimates of CITIC Securities (2013) and Orient Securities (2013). 


\section{Deep Dive: Technologies for Energy Efficient Buildings}

Building energy codes, green building programs, incentives, and energy-efficiency retrofit programs all affect the deployment of energy efficient technologies and products in new and existing buildings. This section discusses market opportunities and barriers for different market segments, including wall and roof insulation, doors and windows, heating, ventilating and air conditioning (HVAC) and controls, and lighting. As the development and implementation of appliance standards are different from those of building programs, this study will not discuss the impact on the market for energy efficient appliances in detail.

\section{Wall and roof insullation Overview}

Chinese energy codes require insulation in buildings to improve energy efficiency. Appendix A lists insulation requirements (i.e. U-factors) for walls and roofs in current building energy codes for different climate zones in China. The insulation market experienced rapid growth starting from late 2000, when the government implemented building energy retrofit projects in northern China.

In 2010, China produced 4.1 million tons of insulation materials for its construction projects, witnessing a vigorous growth at the rate of 15.1\% from 2006 to 2010 (MIIT, 2011). Moreover, the latest policies jointly issued by multiple government agencies further facilitated the development of the building insulation industry by creating predictable demand and lifting policy barriers from the market.

\section{Drivers and Barriers}

Both the Energy Conservation Special Plan for the $12^{\text {th }}$ FYP Period and the Green Building Action Plan require significant endeavors in the realm of insulation in new and existing buildings. To achieve the energy efficiency target set up by the government, over 1.25 billion $\mathrm{m}^{2}$ of new buildings and 90 million of existing buildings need to be insulated (to the U-values stated in Appendix A) each year. Considering the average additional cost of insulation is $100-120$ yuan $(\sim 17-20)$ per $\mathrm{m}^{2}$ relative to no insulation, the relevant policies would help create an extra annual market value up to 125-150 billion yuan ( $\sim 20-25$ billion) for new building insulation and 90-108 billion yuan ( $\sim$ 15-18 billion) for building energy retrofits during the $12^{\text {th }}$ FYP period (Cinda Securities, 2013). MIIT predicts that the market demand for insulation would reach 10 million tons in 2015 if energy efficiency policies and programs are fully implemented with an ideal 100\% implementation rate, which is hard to achieve (MIIT, 2011). However, even if the actual implementation rate might be lower than the planned or reported implementation rate, manufacturers will still see a significant increase in the demand for insulation, as they saw during the $11^{\text {th }}$ FYP period (CITIC Securities, 2013b).

Most Chinese buildings use rigid exterior insulation covered with finishing materials. The former Ministry of Construction tried to promote the use of internal insulation when codes were first being introduced, but because of poor moisture control, condensation was often a problem, and eventually the government promoted exterior insulation instead (Li, 2011). Since then, external wall insulation has become the dominant type of insulation Chinese buildings use, which attracts multiple international players including Dow, Bayer, BASF, and KNAUF and others. 
In general, insulating materials fall into two broad categories: synthetic and mineral materials. The synthetic insulating materials are dominant in the Chinese market, due to better thermal properties and lower price compared to mineral materials, but mineral materials have better fire retardant qualities and are experiencing growth in their market shares. Extruded polystyrene (XPS) and expanded polystyrene (EPS) account for $80 \%$ of the external wall insulation and other synthetic materials like polyurethane (PUR) and polyisocyanurate (PIR) have the market share of 15\%, while the mineral products such as perlite, mineral wool, and glass wool take the remaining $5 \%$ of the insulation market (Sinolink Securities, 2013). However, the market is changing, driven by the improvement in energy efficiency requirements in codes and the growing concerns of fire retardancy of insulation.

Table 5 Key specifications of different insulation materials

\begin{tabular}{|l|c|c|c|c|}
\hline Product & PUR/PIR & EPS & XPS & Mineral Wool \\
\hline $\begin{array}{l}\text { Thermal } \\
\text { Coefficient }\end{array}$ & 0.022 & 0.04 & $0.028-0.04$ & 0.042 \\
\hline $\begin{array}{l}\text { Fireproof } \\
\text { Performance }\end{array}$ & B2-B1 & B2 & B2 & A \\
\hline
\end{tabular}

Source: (Sinolink Securities, 2013).

The Chinese government has growing concerns about fire retardancy of insulation and has made a series changes to the regulations since 2009 (Box 1). As a result, the Chinese government tightened fire retardant requirements; currently, all external wall insulation in China must reach Grade B fire retardancy level $^{8}$ or above (MPS, 2012).
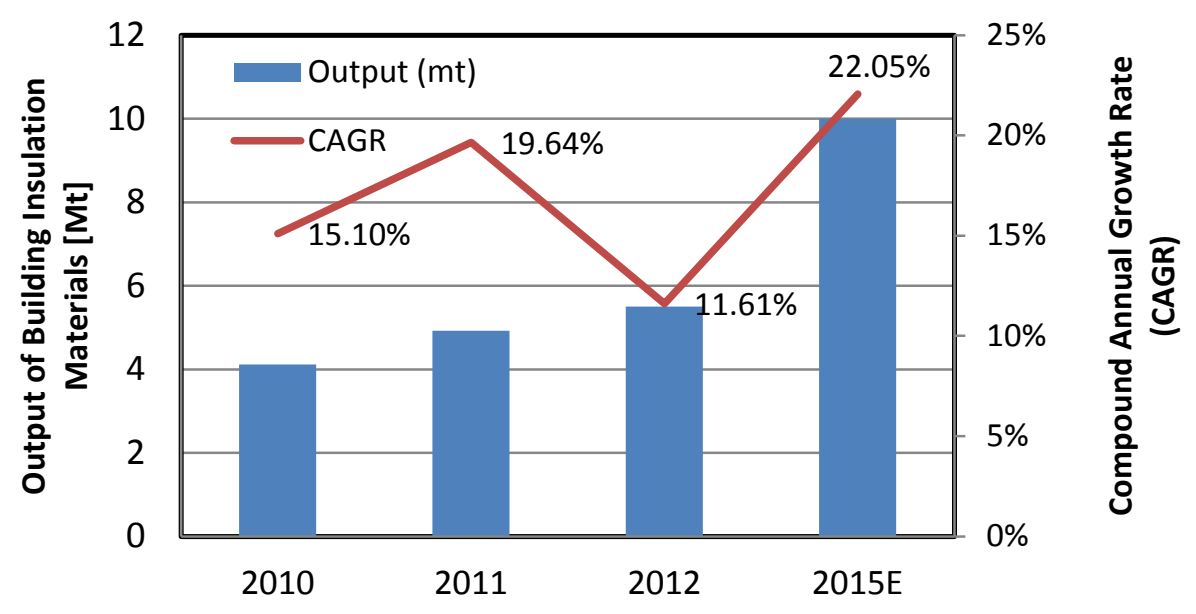

Figure 8 Output of building insulation in China

Sources: (MIIT, 2011; Research and Markets, 2012).

\footnotetext{
${ }^{8}$ The Classification for Burning Behavior of Building Materials and Products (GB 8624-2006) divides the fire retardant performance of building materials into seven different levels, namely A1, A2, B, C, D, E and F. Grade A1 shows that the products have the highest fire retardant performance, while $\mathrm{F}$ means the lowest fire retardant performance. However, the old standard (GB 8624-1997) is still popular in the market, where the fireproof performance is defined as A (Homogeneous Material), A (Nonhomogeneous Material), B1, B2 and B3 from high to low fireproof performance.
} 
Changes in policies also created a significant effect on the market, causing varied growth in building insulation during 2010-2012 (Figure 8). Safety issues are among the top priorities of code officials, who can veto building insulation for use in the market. Concerns about fire safety have delayed existing building retrofits in Shanghai, and probably in other cities concerned as well ( $\mathrm{Du}, 2013)$. At the same time, developers became more cautious about synthetic insulation when constructing new buildings to ensure unsafe products are not being used. Chinese demand for fiberglass and mineral wool will see faster growth as a result of their better fire retardant qualities (Freedonia, 2013).

\section{Box 1. Changes in the fire retardant requirements for insulation in China}

Prior to 2009, most of the thermal insulating materials used in China's new and existing buildings were synthetic. However, the fire that engulfed the headquarter of the China Central Television in 2009 triggered a national discussion on the safety of synthetic materials, which led to the first regulation on fire retardancy of insulation (Security, 2009). The regulation, commonly known as Decree No. 46, set minimal fire retardant standards for insulation installed in both new and existing buildings.

However, this regulation did not prevent such a disaster from happening again. In 2011, two more catastrophic blazes in Shanghai and Shenyang killed over 50 people and caused huge financial losses, which further heightened the safety controversy. In response, the Ministry of Public Security (MPS) issued Decree No. 65 in 2011, setting higher fire retardant standards for insulation, which most synthetic materials fail to meet (MPS, 2011).

The safety ban had several consequences. First, many building energy retrofit projects had to stop, because their insulation failed to meet the fire retardant requirements of Decree No. 65. Second, the market price for insulation experienced a phenomenal growth. Since synthetic materials, which occupied more than $90 \%$ of the market share, were no longer allowed in construction, the demand for mineral insulation overwhelmed the supply (Zhao, 2013). Third, the market turmoil and panic had lowered the quality of insulation products. There were two disparate technical standards for fire retardancy in the market at the same time ${ }^{1}$, but the Decree No. 65 did not explicitly state which system should be used to benchmark the fire retardant performance.

Policy makers noted the need for greater clarity in standards used to implement Decree No. 65, and decided to encourage the sufficient competition among all insulation products by lowering the policy barrier. The measures include replacing Decree No. 65 with the revised Decree No. 46 in 2011 and issuing new technical standards ${ }^{1}$ and testing protocols ${ }^{1}$ (MPS, 2012). The newly revised regulation lower the fire retardant requirements compared to the 2011 regulation and reset the fire retardant requirement to Grade B for insulation materials, and therefore sparked a market recovery of synthetic insulation, at least temporarily (Guodu Securities, 2013). 


\section{Doors and windows}

\section{Overview}

Demand for window and door products in China is forecasted to rise $7.7 \%$ annually to 365 billion yuan ( $\sim 60$ billion) by the end of 2014, which is primarily driven by strong building construction activity. The increase in the average size of homes also contributes to window and door market gains in China (Freedonia Group, 2011). Chinese energy codes have set energy efficiency requirements for doors and windows, which helps promote energy efficient window and door products (Appendix A). In addition, MOHURD has initiated energy efficiency labeling for windows.

\section{Drivers and Barriers}

Policies promoting the development of the industry

Building energy codes have played an important role in facilitating the deployment of energy efficient doors and windows. Served as the most fundamental technical indicator of the standardized measurement of building energy use, U-value has changed several times over the years. For example, the U-value has gone from 2.9-5.8 W/m² $\mathrm{K}$ in 1986 to $2.0-4.7 \mathrm{~W} / \mathrm{m}^{2} \mathrm{~K}$ in 1995 in the severe cold region. In 2010, a newly revised version of the residential code for the severe cold region was released, which targets a $65 \%$ improvement in energy efficiency compared to buildings built in the early 1980s. The U-value requirement in the 2010 version further reduced to as low as $1.5 \mathrm{~W} / \mathrm{m}^{2} \mathrm{~K}$ for the severe cold region (Appendix A).

During the $11^{\text {th }}$ FYP period, the Chinese government has invested more than 15.4 billion yuan (2.5 billion U.S dollars) to conduct energy efficiency retrofits in existing buildings in northern China. With additional financial support from local governments, the encouraging results have been achieved in terms of the retrofitted floor space, the size of which has exceeded its original target of 150 million $\mathrm{m}^{2}$, reaching 182 million $\mathrm{m}^{2}$. This project, started from mid 1990s, has fundamentally changed the market portfolio. With multiple similar completed government funded projects within the nation, around $55 \%$ of the existing windows have reached the requirement of the new building codes (Gold Mantis Construction Decoration Co., 2010). Large-scale retrofits continue during the $12^{\text {th }}$ FYP period and retrofit targets are listed in Table 4.

Recognizing the importance of energy efficient door and window products, the Chinese government has improved the policy guidance for the $12^{\text {th }}$ FYP period. At the national level, several specific plans have pointed out that there will be policy support for energy efficient door and window products that runs through each link of production, development, and consumption in the industry field (MIIT, 2011; MOHURD, 2011b). MIIT and MOHURD are developing the rating system for green building products including windows and doors and will develop a catalog accordingly. Details of the catalog and database for energy efficient building materials are discussed in Appendix B.

The growing demand driven by a favorable policy environment has created a higher profit margin for energy efficient doors and windows, compared to traditional products. Energy efficient doors and windows usually have an average 12 to $15 \%$ profit rate, while traditional products only have 3 to $5 \%$ (China Real Estate Business, 2012). The giant profit gap and the growing demand will drive traditional doors and windows makers to enter the energy efficient market (MIIT, 2011; MOHURD, 2011b). 


\section{Product rating and labeling}

MOHURD initiated a rating program for energy efficient doors and windows in 2006 as an attempt to replicate the success of NFRC's window rating program in China ${ }^{9}$ (Figure 9) (MOHURD, 2006). MOHURD's program tried to promote energy efficient windows during the sales and installation by offering a clear label to help customers understand the energy performance of windows and doors on the market. The rating program is voluntary and some provinces and major cities have developed relevant policies to promote the rating program (MOHURD, 2010d). Beijing, for example, required all manufacturers who register their window and door products with the Beijing Municipal Commission of Housing and Urban-Rural Development to obtain and display energy efficiency ratings for their windows and doors after January 1, 2011. The Beijing Government also required all energy efficiency or green building demonstration projects receiving incentives by the city to use rated windows and doors, and encouraged public buildings and low-income housing to use rated products (Beijing COHURD, 2010). The City of Tianjin also made rating and labeling for energy efficient doors and windows mandatory since January 1, 2014.

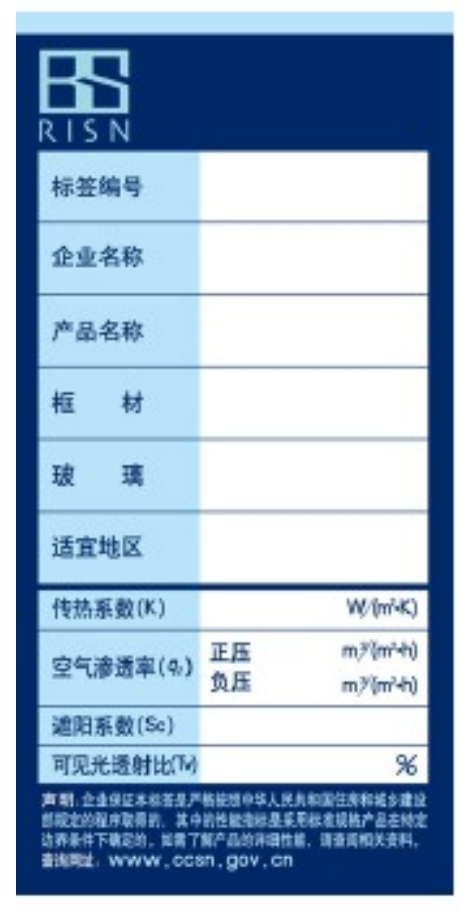

Figure 9 Chinese label for energy-efficient doors and windows

MOHURD also strengthened the testing requirements at the construction site in 2007 with the Acceptance Code. This effort was supported by updated building codes in recent years, yet still has shortcomings since the test samples were provided by the developers or material suppliers of the projects rather than via random selection by officials. Therefore, the problem of market regulation still exists with regard to controlling energy performance of building products.

\footnotetext{
${ }^{9}$ For details, please visit http://www.windowlabel.cn/WebSiteW/Default.aspx.
} 


\section{Case study: Windows with Low-Emissivity Coatings}

Low-e windows, or windows with low-emissivity coatings, have gained a growing share in the Chinese market. The applications of low-e glass range from average buildings, which satisfy basic energy efficiency requirements to public buildings and high-end civil constructions, which meet high energysaving requirements. Thus, the development of low-e glass industry highly correlates with the development of energy efficient windows.

Outstanding growth in demand is changing the market landscape

From 2006 to 2010, the low-e glass industry experienced average annual growth of 58\%, reaching 54 million $\mathrm{m}^{2}$ of total sales in 2010. Low-e glass has accounted for almost all of the growth in sales of window glass over this period, and total window glass sales have grown by only $7 \%$. The market share of low-e glass jumped from 1.3\% in 2006 to almost 7\% in 2010 (Table 6). Further changes in the market landscape are expected as the demand for low-e glass continues to grow.

Table 6 Total sales of low-e glass in China (2006-2010

\begin{tabular}{|l|c|c|c|c|c|}
\hline in thousand square meters & 2006 & 2007 & 2008 & 2009 & 2010 \\
\hline Total consumption of low-e glass & 860 & 1,600 & 2,250 & 3,530 & 5,400 \\
\hline Growth rate & & $86 \%$ & $41 \%$ & $57 \%$ & $53 \%$ \\
\hline Total consumption of construction glass & 68,059 & 72,102 & 76,607 & 81,642 & 87,288 \\
\hline Growth rate & & $6 \%$ & $6 \%$ & $7 \%$ & $7 \%$ \\
\hline Low-e glass's share in total construction glass consumption & $1 \%$ & $2 \%$ & $3 \%$ & $4 \%$ & $6 \%$ \\
\hline CAGR of low-e glass & & & & & $58 \%$ \\
\hline CAGR of total construction glass & & & & & $6 \%$ \\
\hline
\end{tabular}

Source: (Glass, 2011).

Technology advantages of U.S. companies

Despite its dynamic growth, the low-e glass industry is a niche market. Currently, almost all the low-e glass produced in China is made on German or U.S. designed production lines because the technology is patented. It is estimated that a low-e production line with a 700 ton daily capacity would cost a company more than 500 million yuan ( $\sim 83$ million) (UBS Investment Research, 2012).

Giant gap with developed countries demonstrates high market potential

The market penetration of low-e glass, at 7\%, is lower than many developed countries. The gap between China and Germany or South Korea is especially huge, as both have market penetration of more than $90 \%$. The gap demonstrates great market potential in China as the Chinese government continues to promote energy efficient windows. 


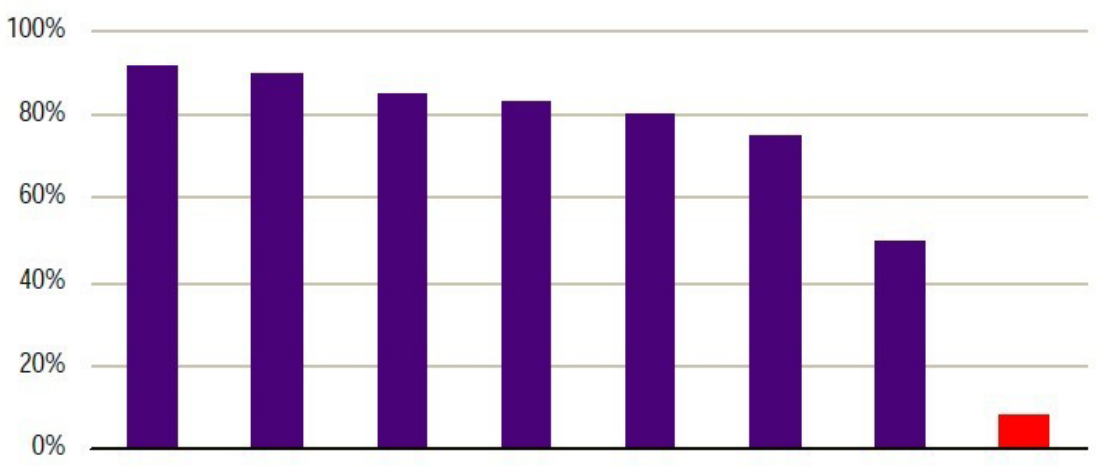

Germany Korea England U.S.A France Poland Japan China

Figure 10 Market penetration rate of low-e glass in the world (2010)

Source: (ResearchInChina, 2010)

Long-term growth in domestic demand drives a stable increase in price

Yet the giant gap between China and other developed countries will be quickly filled by the dramatic increase in policy-driven demand. The latest policy promoting low-e glass is the Green Building Action Plan $^{10}$ issued by NDRC and MOHURD. The plan sets targets for improving compliance with energy codes for new buildings and expanding energy retrofits in existing buildings. Both targets are supported by the Green Building Subsidy from MOF, which instigates demand for energy efficient building products, especially low-E glass.

Private research shows a 33\% annual growth rate through 2015 (Table 7), which is nearly five times the pace of traditional flat glass (UBS Investment Research, 2012). MIIT projects an 18\% growth rate during the same period (MIIT, 2011). Although industry's estimates are more optimistic than the government's estimates, both indicate strong growth during the $12^{\text {th }}$ FYP period.

Table 7 Supply and demand forecast of low-e glass industry, 2011-2015

\begin{tabular}{|l|c|c|c|c|c|}
\hline in thousand square meters & $2011 \mathrm{E}$ & $2012 \mathrm{E}$ & $2013 \mathrm{E}$ & $2014 \mathrm{E}$ & $2015 \mathrm{E}$ \\
\hline Total consumption of low-e glass & 7,402 & 10,788 & 14,692 & 17,966 & 22,320 \\
\hline Growth rate & $37 \%$ & $46 \%$ & $36 \%$ & $22 \%$ & $24 \%$ \\
\hline Total production capacity of low-e glass & 15,390 & 16,929 & 18,621 & 20,484 & 22,533 \\
\hline Growth rate & & $10 \%$ & $10 \%$ & $10 \%$ & $10 \%$ \\
\hline Estimated price change & $-1 \%$ & $9 \%$ & $5 \%$ & $2 \%$ & $2 \%$ \\
\hline
\end{tabular}

Source: (UBS Investment Research, 2012).

\footnotetext{
${ }^{10}$ For details, please visit: http://www.gov.cn/zwgk/2013-01/06/content_2305793.htm.
} 


\section{HVAC and controls}

\section{Overview}

Given its size and terrain, China covers a broad range of climate zones, and Chinese buildings use a range of heating and cooling options. In the north, district heating is common in cities, and room or ductless air conditioners provide cooling. In the south, heating is less common, and when it is available, an electric heater is the main source of heating. Cooling is common in the south, mostly provided by room or ductless air conditioners. Forced, centralized air systems are not very common in China outside of large commercial space. From 2009 to 2012, the Chinese government promoted energy efficient home appliances by providing subsidies and trade-in discounts, and this contributed to the rapid growth in the sales of efficient air conditioners. In 2010, room air conditioners comprised about $65 \%$ of air conditioning expenditure (Deneen et al., 2010).

\section{Policy and business drivers}

China now has the largest HVAC market in the world in terms of the market value. It is also the largest manufacturer of HVAC products. It is estimated that China's HVAC equipment market was 50 billion yuan (7.94 billion U.S dollars) in 2011, increasing by 20\% compared to the same period in previous year (Figure 11). It is predicted that the total Chinese market size will be 110.7 billion yuan in 2015, with a compound annual growth rate of $20 \%$ (Frost \& Sullivan, 2012).

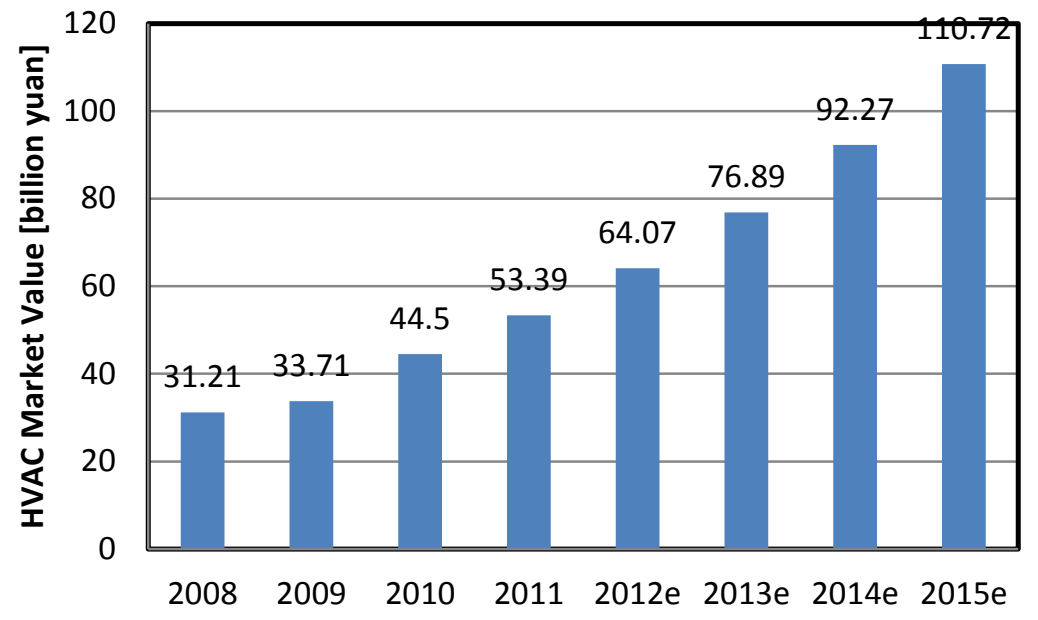

Figure 11 China's HVAC equipment market (excluding district heating), 2008-2015

Source: (Frost \& Sullivan, 2012).

\section{Improving energy efficiency code requirements}

Although the first building energy code was issued in 1986, it was not until 1995 when building codes introduced specific requirements on building heating systems (MOHURD, 1995). The current energy codes specify heating standards for all climate zones, and requirements for heating differ by climate zone and building type (MOHURD, 2010a, 2010b). In northern China, the codes for urban residential buildings favor water heating over air heating. In southern China, heating is not a priority and codes for urban 
residential buildings generally favor air heating. The energy code for rural buildings also has requirements for wood/coal-fired heating system.

Standards for cooling came in the past decade, as air conditioning gradually penetrated the Chinese market. In 2001 and 2003, MOHURD issued special guidelines for HVAC design in energy codes for different climate zones ${ }^{11}$, which set energy efficiency requirements for heating, ventilation, and air conditioning of the building (MOHURD, 2001, 2003). Recent new and updated building codes require higher energy efficiency and operation capacity of the HVAC equipment and further classify the Energy Efficiency Ratio (EER) and Coefficient of Performance (COP) with established standards (MOHURD, 2010c). As the requirements of EER and COP continue to increase (Table 8), more developers are investing in high performance HVAC systems. Table 8 gives an example of EER requirements in the energy code for cold and severe cold regions. The detailed requirements on COP and EER for different climate regions could be found in the Chinese building energy codes, which are listed in Table 2.

Table 8 EER requirements for room air conditioners (severe cold and cold regions)

\begin{tabular}{|l|c|c|c|c|}
\hline Category & $\begin{array}{c}\text { CC (Rated Cooling } \\
\text { Capacity) (W) }\end{array}$ & \multicolumn{2}{|c|}{ EER (W/W) } & $\begin{array}{c}\text { SEER } \\
{\left[\mathrm{W}^{*} \mathrm{~h} /\left(\mathrm{W}^{*} \mathrm{~h}\right)\right]}\end{array}$ \\
\cline { 3 - 5 } & & $\begin{array}{c}\text { Energy } \\
\text { Performance level } \\
2 \text { in GB 12021.3- } \\
2004^{12} \text { standard }\end{array}$ & $\begin{array}{c}\text { Energy } \\
\text { Performance level } \\
2 \text { in GB 12021.3- } \\
2010^{13} \text { standard }\end{array}$ & $\begin{array}{c}\text { Energy } \\
\text { Performance level } \\
2 \text { in GB 21455- } \\
2008^{14} \text { standard }^{-}\end{array}$ \\
\hline $\begin{array}{l}\text { Package Room Air } \\
\text { Conditioner }\end{array}$ & - & 2.9 & 3.1 & - \\
\hline 3.0 & $\mathrm{CC} \leq 4500$ & 3.2 & 3.4 & 4.5 \\
\cline { 2 - 5 } & $4500<\mathrm{CC} \leq 7100$ & 3.1 & 3.3 & 4.1 \\
\cline { 2 - 5 } & $7100<\mathrm{CC} \leq 14000$ & 3.0 & 3.2 & 3.7 \\
\hline
\end{tabular}

Source: (MOHURD, 2010c).

\section{Government funded energy retrofits in northern China promotes high performance HVAC}

As building codes improve energy efficiency standards of HVAC systems for new buildings, building energy retrofits provide an opportunity to improve the performance of space heating/cooling facilities by introducing better HVAC systems for existing buildings. The district heating service in China experienced a double-digit growth in recent years, and the conditioned floorspace jumped from 1.5 billion $\mathrm{m}^{2}$ in 2004 to 3.4 billion $\mathrm{m}^{2}$ in 2011 (Figure 12). At present, more than 99\% of the urban district-heated housing area comes from northern China (Figure 13) (NBSC, 2012), and this represents 40\% of total urban building energy consumption in China (MOHURD, 2011a). Therefore, creating incentives for conservation in district-heated buildings could achieve considerable energy savings.

\footnotetext{
${ }^{11}$ Design Standard for Energy Efficiency of Residential Buildings in Hot Summer and Cold Winter Zone (JGJ 1242001), MOHURD; Design Standard for Energy Efficiency of Residential Buildings in Hot Summer and Warm Winter Zone (JGJ 75-2003), MOHURD.

${ }^{12}$ The Minimum Allowable Values of the Energy Efficiency and Energy Efficiency Grades for Room Air Conditioners, AQSIQ, 2004.

${ }^{13}$ The Minimum Allowable Values of the Energy Efficiency and Energy Efficiency Grades for Room Air Conditioners, AQSIQ, 2010.

${ }^{14}$ Minimum Allowable Values of Energy Efficiency and Energy Efficiency Grades for Variable Speed Room Air Conditioners, AQSIQ, 2008.
} 

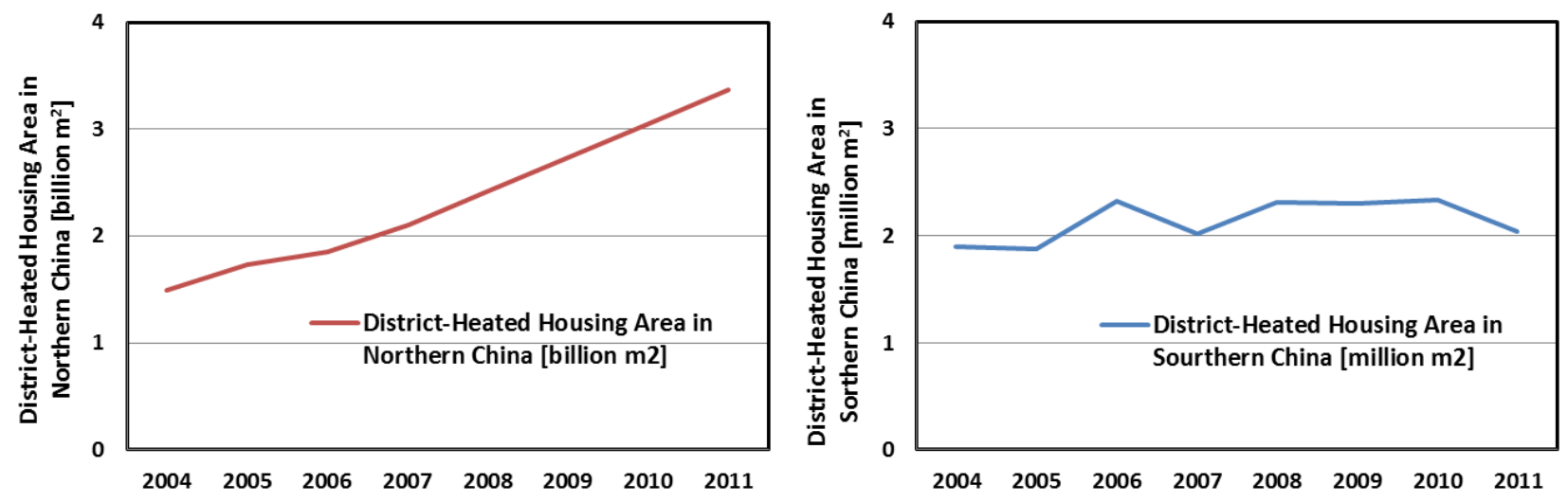

Figure 12 District-heated housing area in urban China (2004-2011)

Source: (NBSC, 1999, 2006, 2010, 2012).

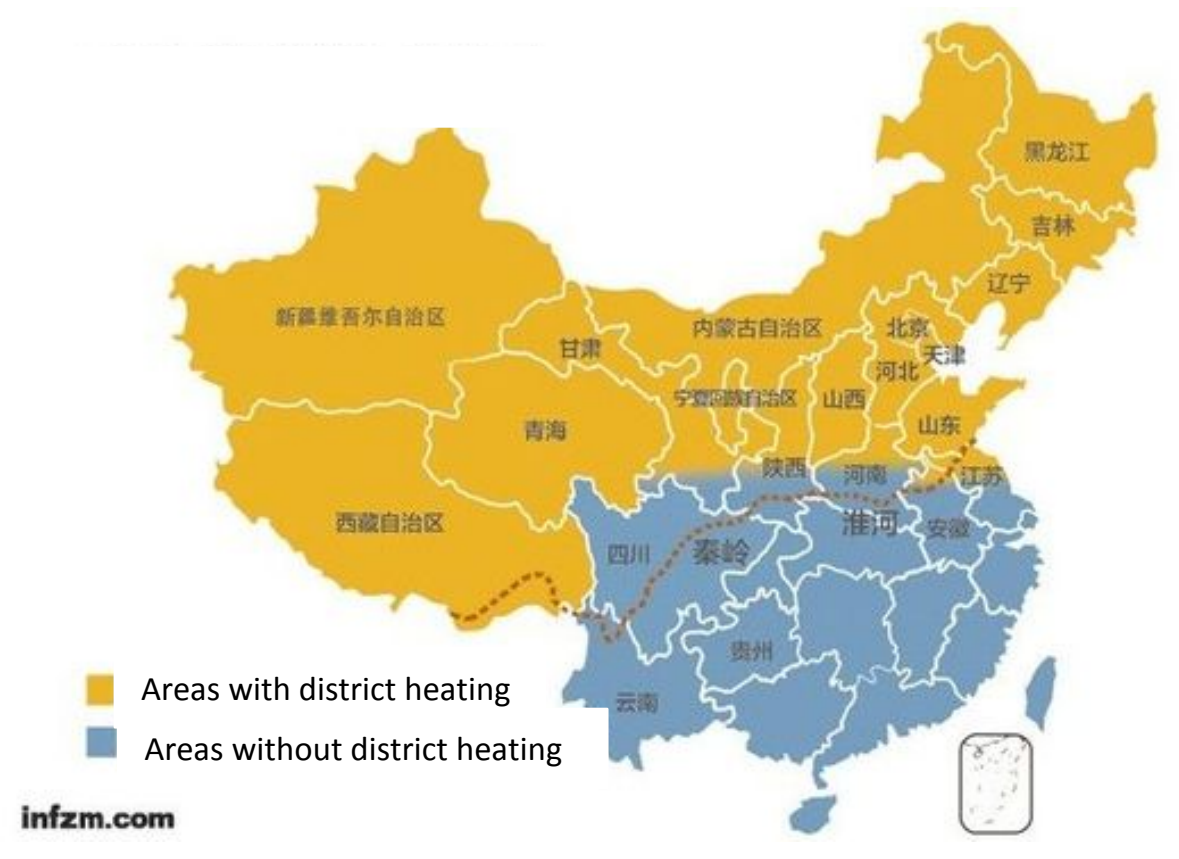

Figure 13 Provinces with and without district heating

Note: Provinces and cities with significant district heating systems for residential heating in Northern China include Beijing, Tianjin, Hebei, Shanxi, Inner Mongolia, Liaoning, Heilongjiang, Shandong, Henan, Shaanxi, Gansu, Qinghai, Ningxia and Xinjiang.

In response to barriers inhibiting residential retrofits, MOF issued financial incentives for buildings in northern China in 2007 with a target of 1500 million $\mathrm{m}^{2}$ of floorspace by the end of 2010 (MOF, 2007). Energy retrofits in northern China have two aspects: building energy retrofits and heat metering reform. Building retrofits tend to focus on renovating the envelope of existing buildings; while heat metering reform requires residents to pay for heat based on their consumption instead of their proportion of the overall floorspace serviced by the district heating system (MOHURD et al., 2010; Qiu, 2010). The 
amount of retrofitted floorspace exceeded the target by about $20 \%$ during the $11^{\text {th }}$ FYP; which inspired a more ambitious target of 4000 million $\mathrm{m}^{2}$ in northern China for the $12^{\text {th }}$ FYP (MOHURD, 2011b).

As the forced air system retrofit program continues to take effect, HVAC industry is expected to benefit from the policy incentive. Consumers in southern China are also transferring from A/C to HVAC for heating and better ventilation of the building (HVAC China, 2013).

Commercial sector boom and residential buildings with advanced energy efficient standards increases the demand for HVAC

Commercial buildings in China have long used forced air heating and cooling systems to provide indoor climate control, and around 50\% of all 10+ story buildings are expected to be built through 2020, which constitutes the major market for forced air systems in China. U.S. companies have already benefited from the growth in China's commercial building sector, and is expanding its capacity locally to meet the demand in China (Trefis, 2013).

\section{Government Incentives for Efficient Air Conditioners}

\section{HVAC sales in China}

In 2009, China has a reported 19 major air conditioner name brands, with around 100 suppliers of air conditioners in China, producing over 9,500 different product models. About $60 \%$ of China's domestic sales of air conditioners come from four major manufacturers (i.e. Haier, Hisense, Chonghong, and Midea) (Centre for Strategic Economic Studies, 2010).

The top three Chinese manufacturers, Haier, Midea, and Gree, can supply 50\% of the world's demand for HVAC products (PR Newswire, 2013), while the domestic market is roughly divided into four segments fulfilled by manufacturers from China mainland, Europe, United States, Japan and Korea as well as other countries (Figure 14).

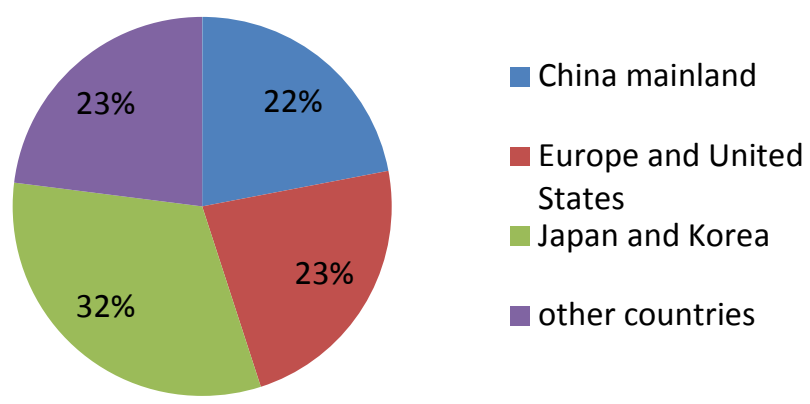

Figure 14 Domestic HVAC sales by origin

Source: (Frost \& Sullivan, 2012).

Room air conditioners will stop growing due to policy expiration 
From 2009 to 2012, the Chinese government promoted energy efficient home appliances by providing subsidies and trade-in discounts, which triggered the three-year bullish market for the industry of room air conditioners. However, manufacturers had overestimated the impact of the policy and underestimated the risk from raw materials and labor costs. Due to the end of the 2011 incentives, the room air conditioning sales volume decreased sharply in China. This decrease left huge amounts of inventory for manufacturers, reaching more than 20 million units by the end of 2011 (China Daily, 2012).

\section{Central air conditioners deteriorated in 2012}

Benefit from the quick urbanization trend and high investment in construction activities, the average growth of the industry of central air conditioners has enjoyed a notable pace at around $20 \%$ annually (excluding the data from 2008 and 2009, which was affected by global economic downturn) (HVAC China, 2013). However, as the property tightening measures continues to take effect in 2012, the industry of central air conditioners suffered a dramatic slow-down: the market size declined from 57.5 billion yuan in 2011 to 57.2 billion yuan in 2012, with a sharp drop in growth rate from $28.1 \%$ to $-0.5 \%$ (Figure 15).

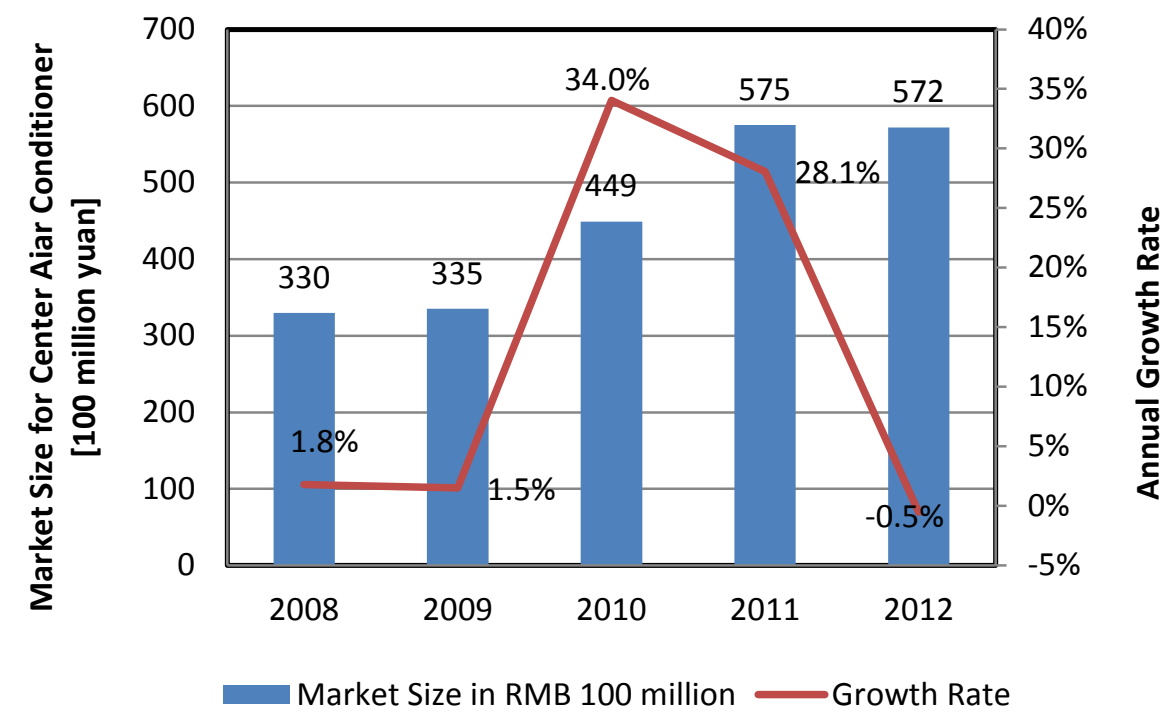

Figure 15 Equipment sales of the central air conditioner industry in China (2008-2012)

Source: (HVAC China, 2013).

The domestic market for indoor heating and cooling is experiencing an intense competition in traditional markets such as room air conditioners and central air conditioners, where the market is stable or even declining due to policy and economic factors. However, the HVAC segment remains highly profitable due to its technology threshold. U.S. manufacturers generally focus on the high-end market with advanced technologies and products for the Chinese market. However, concerning the unprecedented size and scale of energy retrofits in northern China as well as green building projects funded by the Chinese government, it is evenly important, if not more, to invest in related products accordingly. As policy guidance and incentives keep functioning well, it is highly likely that China will transform its indoor heating and cooling market towards higher energy efficiency level, where HVAC industry will thrive in the changing market. 


\section{Controls and Building Automation System}

\section{Overview}

Controls or building automation systems are centralized, integrated networks of hardware and software, which monitor and control the environment in commercial and residential facilities. HVAC control system, among one of the core components of controls, creates an intelligent building by reducing energy and maintenance costs, while providing a comfortable indoor climate for the residents. Thus, analysis on the control market in China would provide visionary insights for the HVAC industry.

In 2012, the controls market in China was estimated to be worth 181.6 million U.S. dollars, nearly onetenth the size of the U.S. market. However, despite its limited scale at the moment, the controls market in China is forecasted to grow at a compound annual growth rate of $13.7 \%$, reaching 344.5 million U.S. dollars in 2017 (Liu, 2013) (Figure 16).

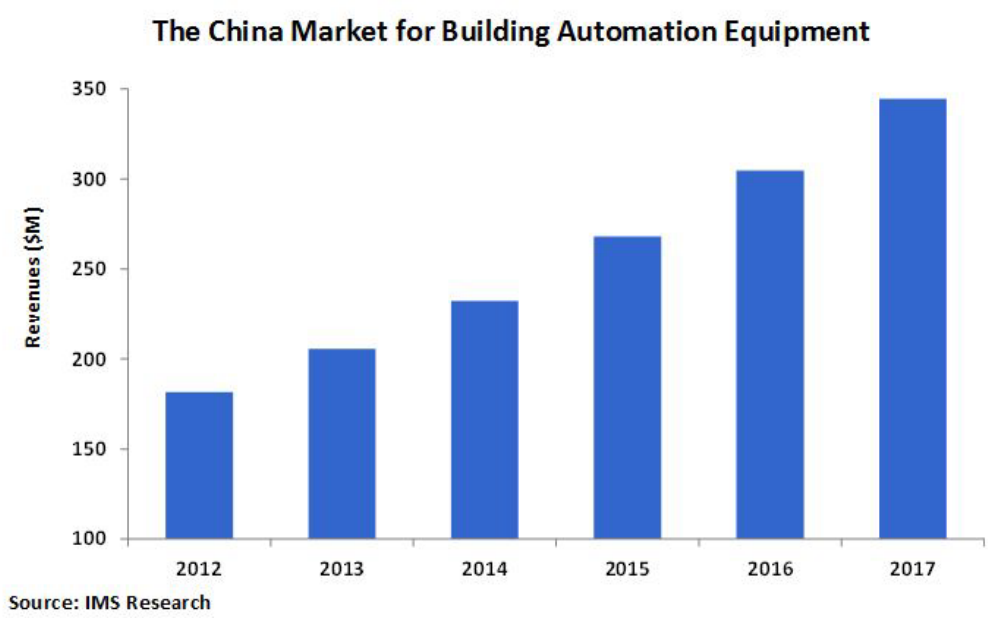

Figure 16 Sales of building automation equipment in China

Green building incentives and smart city investments

Chinese government's promotion for green buildings is one of the key drivers of the control market in China. The increasing green building space within China will accelerate the growth of the control market in China.

\section{Tailored services}

The control market in China is experiencing a market transition from basic functions such as turning on/off equipment and basic control of temperature and humidity towards a more integrated, intelligent, and energy efficient way to monitor, analyze, coordinate, and control the facility network that sustains the indoor environment of the buildings. The control industry in China provides tailored services for different types of buildings, targeting different functions and occupancy levels. For example, data centers have severs running 24 hours a day, and they need the control system to keep the right operating temperature, humidity, and pressure all the time. Companies that are able to answer specific questions posed by different types of buildings are likely to take a decent share of the increasing control market in China. Lighting controls will be discussed in the next section with the lighting system. 


\section{Lighting}

Overview

China is a large and growing player in the global lighting market, both in terms of production and domestic sales. In order to promote energy efficient lighting products in China, Chinese policymakers are phasing out incandescent bulbs and providing policy incentives for more efficient products, in particular compact fluorescent lamps (CFLs) and light-emitting diodes (LEDs). Beyond the policy dynamics in the lighting industry, the private sector sees notable business opportunities in energy efficient lighting. However, several issues still create barriers to greater expansion of efficient lighting in China. International companies with better technologies and management knowledge will solve the issues as they enter the market, and their advantages will bring reasonable profit in China.

\section{Policy Drivers and Incentives}

\section{Lighting code}

Unlike U.S. building energy codes, Chinese energy codes for building design do not including lighting requirements. Lighting is governed by a separate code called the Standard for Lighting Design of Buildings, which specifically lists requirements for lighting power density for different types of buildings and regulates lighting controls. MOHURD issued the first lighting code in 1990 and updated the code in 2004 and 2013.

The lighting code suggests the application of lighting controls in large commercial, industrial, and public buildings with centralized control systems and automatic lighting shutoffs. In addition, the lighting code refers to testing and rating systems for lighting products. The Chinese government has developed ratings for eight lighting products so far, covering fluorescent lamp, high voltage sodium lamp, metal halogen lamp as well as their ballasts (AQSIQ, 1999, 2003a, 2003b, 2003c, 2004a, 2004b, 2006a, 2006b).

\section{Incentives for CFLs and energy efficient lighting}

The Chinese government provided subsidies and incentives to encourage the deployment of energy efficient lighting products in recent years. In 2007, the central government added CFL to its procurement list (Office of State Council, 2007). In 2008, the Chinese government started to subsidize the price of energy efficient lighting products by $30 \%$ under special programs to promote the development of the industry (NDRC and MOF, 2008). From 2008 to 2012, subsidies helped promote and install 680 million energy efficient light bulbs. Subsidies and incentive programs also raised market awareness and significantly enhanced the market share of energy efficient lighting, especially CFLs. In 2010, there are 2.9 billion CFLs used in residential, industrial, commercial, and public buildings in China.

\section{Phase-out of incandescent in China}

In 2009, NDRC, UNDP, and GEF formulated a roadmap of incandescent phase-out in China. The roadmap required a gradual phase-out of incandescent lights in China and promoted energy efficient products. The Chinese government has recently revised the proclamation of the phase-out in 2011, and proposed five steps to gradually phase out incandescent lights, which were backed by China's Energy Conservation Law. Table 9 describes the roadmap of the phase-out policy in China. 
Table 9 Roadmap of the incandescent phase-out policy in China

\begin{tabular}{|c|c|c|c|c|c|}
\hline Steps & $\begin{array}{l}\text { Implementation } \\
\text { Period }\end{array}$ & Target Products & $\begin{array}{l}\text { Rated } \\
\text { Power }\end{array}$ & $\begin{array}{l}\text { Scale and } \\
\text { Measures }\end{array}$ & Notes \\
\hline 1 & $\begin{array}{l}\text { October } 1^{\text {st }}, 2011 \\
\text { to September } \\
30^{\text {th }}, 2012\end{array}$ & \multicolumn{3}{|c|}{ Transition period: one year } & $\begin{array}{l}\text { Issue notices and } \\
\text { roadmap }\end{array}$ \\
\hline 2 & $\begin{array}{l}\text { Start from } \\
\text { October } 1^{\text {st }}, 2012\end{array}$ & $\begin{array}{c}\text { Ordinary illumination } \\
\text { incandescent lights }\end{array}$ & $\geqslant 100 \mathrm{~W}$ & $\begin{array}{l}\text { Ban import and } \\
\text { domestic sale }\end{array}$ & - \\
\hline 3 & $\begin{array}{l}\text { Start from } \\
\text { October } 1^{\text {st }}, 2014\end{array}$ & $\begin{array}{l}\text { Ordinary illumination } \\
\text { incandescent lights }\end{array}$ & $\geqslant 60 \mathrm{~W}$ & $\begin{array}{l}\text { Ban import and } \\
\text { domestic sale }\end{array}$ & $\begin{array}{c}\text { Issue Tungsten } \\
\text { halogen lamps } \\
\text { energy efficiency } \\
\text { standards, ban } \\
\text { production, import } \\
\text { and sales of those } \\
\text { who do not meet the } \\
\text { standards. }\end{array}$ \\
\hline 4 & $\begin{array}{l}\text { October1st, } 2015 \\
\text { to September } \\
30^{\text {th }}, 2016\end{array}$ & \multicolumn{4}{|c|}{ Conduct Mid-term assessment, adjust subsequent policy } \\
\hline 5 & $\begin{array}{l}\text { Start from } \\
\text { October } 1^{\text {st }}, 2016\end{array}$ & $\begin{array}{l}\text { Ordinary illumination } \\
\text { incandescent lights }\end{array}$ & $\geqslant 15 \mathrm{~W}$ & $\begin{array}{l}\text { Ban import and } \\
\text { domestic sale }\end{array}$ & $\begin{array}{l}\text { The final time and } \\
\text { products of banning, } \\
\text { and whether to ban } \\
\text { production will } \\
\text { depend on the mid- } \\
\text { term assessment of } \\
2015 \text {. }\end{array}$ \\
\hline
\end{tabular}

Source: (International SSL Alliance, 2013).

\section{Market Impact Forecast}

The energy efficient lighting market in China starts with government promotion in 1996. But the real initiative began in 2008, when large-scale government subsidy was implemented to promote energy efficient products. In 2010, 70\% of the lighting products in use in the Chinese market were energy efficient, and LED lights started to penetrate the market (NDRC, 2012). With strong policy support and favorable business environment, China now has become the biggest market of energy efficient lighting products.

The China lighting market is estimated to reach 14 billion U.S. dollars in 2012, accounting for $45 \%$ of Asian lighting market (Table 10). Through years of policy promotion of efficient lighting, only 6\% of the total sales go to incandescent in 2012. At the same time, LED sees a great increase in market share from $12 \%$ in 2011to $18 \%$ in 2012. Business forecast shows that it will experience an even more promising future in 2020, when the market size for lighting products in China doubles with $69 \%$ market share of LED products (McKinsey \& Company, 2012).

Table 10 Forecast of the Chinese lighting market (by products)

\begin{tabular}{|l|c|c|c|c|c|}
\hline & Unit of measure & 2011 & 2012 & 2016 & 2020 \\
\hline Total market & USD m & 12,614 & 14,344 & 19,754 & 25,387 \\
\hline
\end{tabular}




\begin{tabular}{|c|c|c|c|c|c|} 
Excl. lighting control system market & USD m & 12,401 & 14,077 & 19,152 & 24,088 \\
\hline Incandescent & $\%$ & 7 & 6 & 1 & 0 \\
\hline Halogen & $\%$ & 8 & 8 & 5 & 2 \\
\hline HID & $\%$ & 12 & 11 & 7 & 4 \\
\hline LFL & $\%$ & 41 & 39 & 29 & 19 \\
\hline CFL & $\%$ & 19 & 17 & 12 & 6 \\
\hline LED & $\%$ & 12 & 18 & 46 & 69 \\
\hline Luminaire market & USD m & 10,872 & 12,346 & 16,988 & 22,035 \\
\hline Light source replacement market & USD m & 1,529 & 1,743 & 2,164 & 2,053 \\
\hline Lighting control system market & USD m & 213 & 268 & 602 & 1,301 \\
\hline
\end{tabular}

Source: (McKinsey \& Company, 2012).

Note: the market value has been converted from 2010 euro to 2010 USD at the exchange rate of 1 euro=1.3178 USD (source: http://www.ecb.europa.eu/stats/exchange/eurofxref/html/eurofxref-graphusd.en.html)

Although LED took 18\% of the total market in 2012, residential application is still rare in China. The increase was driven by non-residential applications, as CFL is still the dominant technology in the residential market. The outdoor sector, as an example of strong government support, has a higher penetration rate of LED products. However, sales in the residential sector are expected to grow 2.5 times by the end of 2020, in part because of the phase-out of incandescent bulbs.

Table 11 Forecast of the Chinese lighting market (by segment in million USD)

\begin{tabular}{|l|c|c|c|c|}
\hline & 2011 & 2012 & 2015 & 2020 \\
\hline Total market & 12,614 & 14,344 & 19,754 & 25,387 \\
\hline Excl. lighting control system market & 12,401 & 14,076 & 19,152 & 24,088 \\
\hline Residential & 2,877 & 3,216 & 4,848 & 6,752 \\
\hline Hospitality & 1,796 & 2,047 & 2,404 & 2,608 \\
\hline Outdoor & 1,150 & 1,172 & 1,364 & 1,560 \\
\hline Office & 2,854 & 3,322 & 4,807 & 6,665 \\
\hline Architectural & 996 & 1,096 & 1,502 & 2,073 \\
\hline Shop & 1,967 & 2,350 & 3,323 & 3,884 \\
\hline Industrial & 973 & 1,141 & 1,505 & 1,848 \\
\hline
\end{tabular}

Source: (McKinsey \& Company, 2012).

Note: the market value has been converted from 2010 euros to 2010 USD at the exchange rate of 1 euro=1.3178 USD (source: http://www.ecb.europa.eu/stats/exchange/eurofxref/html/eurofxref-graphusd.en.html).

\section{Growth of LED Lighting}

The development of energy efficient lighting system in China has long been supported by both strong $R \& D$ efforts from all sectors and favorable industrial policies from the national and local governments in China. It is without doubt that the energy efficient lighting industry, especially the LED industry, has benefitted from strong and effective policy measures and development plans. However, it is also very important to understand that Chinese policymakers are continuously revising the policies to address real- 
time challenges. Industry practitioners should keep in mind that the trend and impact of the current policies are adapting to new environments and situations.

\section{Promoting LED lighting}

The Chinese government first recognized the importance of energy efficient lighting products in the mid1990s, when the government initiated the "Green Lighting Project”(Min et al., 1995). However, it was not until 2009 when the first national policy advice was issued by multiple organizations(NDRC, 2009). The document illustrated the current situation and trends of the LED energy conservation industry, identified the major problems, and proposed guiding ideas, basic principles, development targets, and focal areas.

In 2012, the "Specific Plan of the $12^{\text {th }}$ FYP for Semiconductor Lighting Science and Technology Development” was issued by the Ministry of Science and technology (MOST). The plan projected that the total domestic market size would see annual sales of 500 billion yuan by the year 2015. It further set a goal the LEDs would account for $30 \%$ of new lighting sales, in part through targeted efforts in 50 pilot cities.

The latest policy on the LED industry is the "Guidelines for the Energy Efficient Semiconductor Lighting Industry” jointly issued by NDRC, MOST, MIIT, MOF, MOHURD and AQSIQ. The guidelines highlight not only the potential of more than $35 \%$ growth during the $11^{\text {th }}$ FYP period (2006-2010), but also the challenges that the industry faces, including (1) production capacity surplus, (2) lagging R\&D and (3) over-intensified market competition. The new guidelines reiterate some of the targets from MOST's plan, such as the penetration rate and domestic production rate of the LED products. Moreover, the guidelines unveil some new policies and measures to help implement the targets in MOST's plan. The guidelines also lower of the projection of market size in 2015 by 50 billion yuan to 450 billion yuan.

\section{Incentives and public procurements}

Since 2007, the Chinese government has issued several policy incentives featuring tax reductions and product promotions with the energy efficient lighting industry(NDRC, 2007; NDRC, 2008). Since lighting retrofits are among the most popular service of energy service companies (ESCOs) in China, and the energy efficient lighting market has also benefitted from the ESCO promotion policies in 2010 (NDRC, 2010), which provides financial support and tax deductions for ESCOs.

Recently the incentive policy focused on direct subsidies for energy efficient lighting products, which further encouraged the development of the industry. In 2012, the State Council decided to allocate 2.2 billion yuan to support the promotion of 10 million LED bulbs for room lighting and 1 million for outdoor lighting. Later MOF, NDRC and MOST jointly launched the 2012/2013 LED products Financial Subsidy Promotion Program, the program covered indoor lighting products - LED downlights, reflective self-ballasted LED lamps, outdoor lighting products-LED street lights, LED tunnel lights. The program was estimated to reach a total subsidy of more than 2 billion yuan, subsidizing about $30 \%$ of product price.

Another major measure to implement the promotion of energy efficient lighting products, especially the LED lights is public procurements. Other than policy incentives that lower the price of the products in the market, public procurements create actual demand for the products, which directly supports the development of the industry. 
In 2007, the Office of State Council issued "Notice on establishing the compulsory governmental procurement mechanisms for energy conservation products”, required that the energy conservation products should be a priority in consideration of government procurement, and for those whose energy conservation effects and quality meets requirements should be compulsory procurement.

In 2008, China launched the "Energy Conservation Regulations for Public Agencies”, which requires all level of government agencies should include the energy conservation products and equipment into the government procurement list. Meantime the Civil Construction Energy Conservation Regulation was also released, which requires construction companies to choose suitable renewable energy for heating, cooling, lighting, and hot water. These two regulations provided legal sources for local government to include LED products into the procurement list.

\section{Industry challenges}

Given China market is expected to thrive, several challenges should be identified before analyzing the market opportunities, in particular, chaotic competition and quality control and incomplete testing and rating system.

Because there are many Chinese producers of LED products, domestic players in China have to compete by offering lower price to consumers; this in turn leads to lower quality products. Moreover, since Chinese manufacturers have invested heavily in LED chip and package lines, they now have considerable excess production capacity. As China is one of the leading export countries of LED products, global market will also see a reduction in price.

In addition, quality control seems to be hard to achieve due to the cost issue in China. One major consequence is the short life cycle. Although domestic products have caught up with their international counterparts in energy efficiency, domestic products are known for their short life cycle. Compared to an average life cycle of 100,000 hours from international typical example, domestic products usually last for 5,000 to 6,000 hours. The vicious circle of "low-price-low-quality" has already slowed the development of LED industry in China. At the same time, this presents an opportunity for high-quality providers that will compete not just on price.

China's system of testing and rating LED products is ripe for improvement. MOST recently laid out a plan for establishing a more robust testing and rating system in the $12^{\text {th }}$ FYP (MOST, 2012), however, the system if far from complete. Such a system will help the development of the LED industry by allowing consumers to trust the products they buy, which in turn will allow prices to rise along with quality.

Yet market opportunities still exist, especially for international companies. International companies with advanced technologies, good quality control will help improve customer trust and sales. Such companies can also assist the Chinese government in establishing industrial standards and regulating the industry. 


\section{Existing Buildings: Energy Performance Contracts in Public Buildings ${ }^{15}$}

China has a stock of 43 billion $\mathrm{m}^{2}$ of existing buildings, most of which have poor thermal properties and less efficient heating and cooling systems than developed countries (ERI, 2009). The Chinese government has made great progress in retrofitting existing buildings for energy efficiency, focusing on two categories of buildings: residential buildings in northern China and large public buildings.

The northern heating area, with 15 provinces and cities, hosts 7 billion $\mathrm{m}^{2}$ of floorspace. Heating services in this area consumed about 98 Mtoe in 2008, accounting for 30\% of total building energy use in China. Energy use intensity for heating is 0.021 toe per $\mathrm{m}^{2}$ per year, which is two to three times higher than that of developed countries in a similar climate zone. The Chinese government set mandatory targets for improving energy efficiency in residential buildings, and from 2006 to 2010, cities and provinces in northern China have conducted energy-efficiency retrofits in 182 million $\mathrm{m}^{2}$ of residential buildings, with an estimated investment of 46-64 billion yuan (ERI, 2009). Since previous sections have discussed the heating reforms and impacts of energy-efficiency retrofits in residential buildings in northern China, this section will focus on the market potential and opportunities in public building retrofits. In addition, as the previous section has discussed the impacts of public building retrofits on technologies and the building materials industry, the second half of this section will elaborate on the opportunities and barriers for ESCOs in implementing energy-efficiency retrofits in public buildings.

\section{Market opportunities in public building retrofits}

There are around 1.9 million public institutions in China, which occupy about 6 billion $\mathrm{m}^{2}$ of floorspace. Energy use in public buildings has grown rapidly and increased by 15\% from 2005 to 2010 (Figure 17). Meanwhile, during the $11^{\text {th }}$ FYP period when the government actively pursued a range of efficiency policies and programs, energy intensity declined by 15\% from 2005 to 2010 (Table 4; Figure 17).

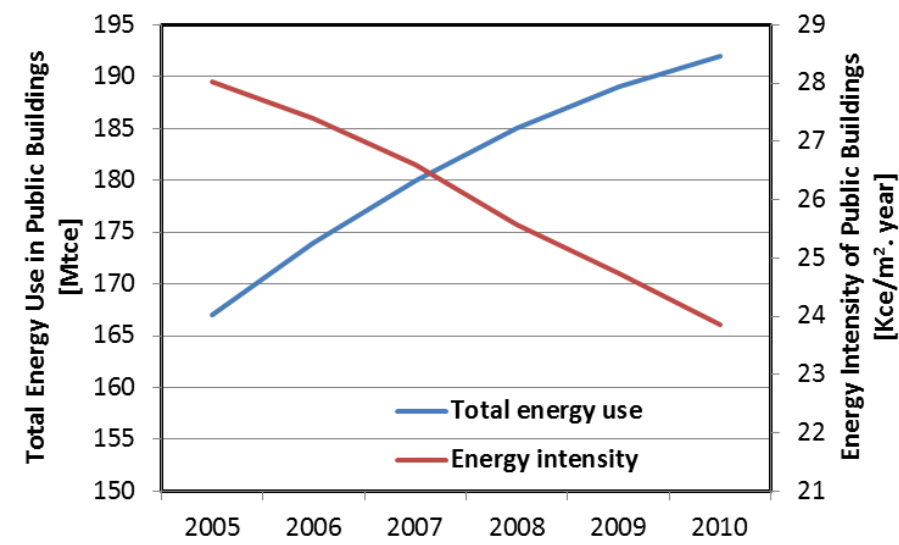

Figure 17 Energy consumption in public buildings (2005-2010)

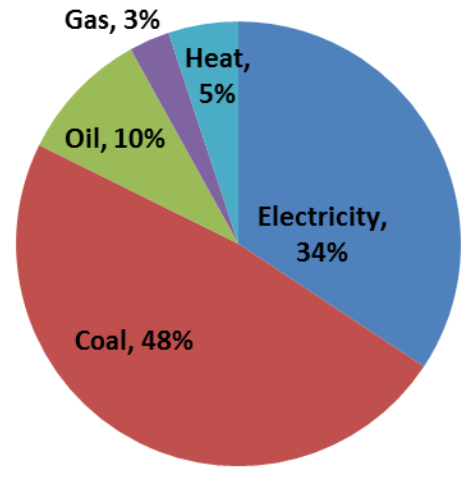

Figure 18 Fuel profile of public buildings (2010)

Source: (GOA, 2011).

Coal and electricity are major fuel sources for public buildings and together they account for more than $80 \%$ of the total energy use in public buildings (Figure 18). The share of new and renewable energy in

\footnotetext{
${ }^{15}$ Public buildings in this report refer to buildings owned or occupied by government or government-sponsored entities. Definitions of public and commercial buildings used in this report are discussed in the footnote 1 in detail.
} 
public buildings is currently low, but the share is expected to increase in the near future as the Chinese government develops pilot programs and encourages the application of building-integrated photovoltaics, solar heating and cooling, and geothermal heat pumps.

To accelerate energy efficiency improvements in public buildings and encourage the transition to clean fuels, the Chinese government has set energy-efficiency goals for public buildings. Compared to 2010, public buildings need to lower their per capita energy use and energy intensity by $15 \%$ and $12 \%$, respectively. Meanwhile, the $12^{\text {th }}$ FYP for public buildings also envisages the development of policies, energy management systems, energy audit and monitoring programs, technology deployment, training and capacity building, and market mechanisms for energy-efficiency retrofits in public buildings. The goal is broken down into several tasks, as shown in Table 12.

Table 12 Programs improving energy efficiency in public buildings (2011-2015)

\begin{tabular}{|c|c|c|}
\hline Name & Content & Key targets during $12^{\text {th }} \mathrm{FYP}$ \\
\hline $\begin{array}{l}\text { Demonstration } \\
\text { projects for } \\
\text { energy } \\
\text { efficiency } \\
\text { retrofits in } \\
\text { public buildings }\end{array}$ & $\begin{array}{l}\text { Energy efficiency retrofits in } \\
\text { government buildings, schools } \\
\text { and hospitals }\end{array}$ & $\begin{array}{l}\text { - } 2,000 \text { institutions } \\
\text { - } \quad 60 \text { million } \mathrm{m}^{2} \text { of retrofitted floorspace } \\
\text { - } \quad 4.2 \text { Mtoe of energy conservation }\end{array}$ \\
\hline $\begin{array}{l}\text { Green lighting } \\
\text { project }\end{array}$ & $\begin{array}{l}\text { Energy efficient lighting and } \\
\text { control systems public institutions } \\
\text { at all levels }\end{array}$ & $\begin{array}{l}\text { - } 25 \text { million units of energy efficient lighting } \\
\text { products (CFL, straight tube fluorescent lamps, } \\
\text { HPS lamp, metal halide lamps and LED lights) } \\
\text { - } 100 \% \text { energy efficient lighting application in } \\
\text { office area (mandatory) } \\
\text { - } 10 \% \text { application of LED in all applications } \\
\text { (voluntary) } \\
\text { - } 420,000 \text { toe of annual energy conservation }\end{array}$ \\
\hline $\begin{array}{l}\text { Green data } \\
\text { center project }\end{array}$ & $\begin{array}{l}\text { Energy efficiency upgrades and } \\
\text { retrofits for data centers }\end{array}$ & $\begin{array}{l}\text { - } \quad 1,000 \text { data centers for public institutions } \\
\text { - } \quad 280,000 \text { toe of annual energy conservation }\end{array}$ \\
\hline $\begin{array}{l}\text { Zero stand-by } \\
\text { energy } \\
\text { consumption } \\
\text { project }\end{array}$ & 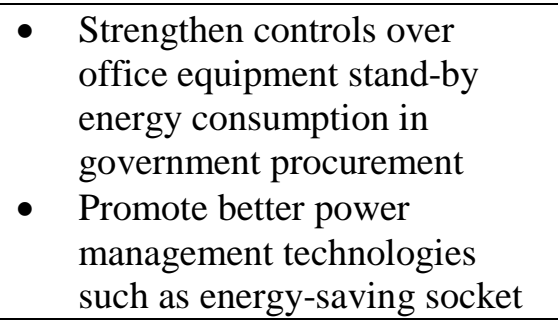 & $\begin{array}{l}\text { - } 12 \text { million units of energy-saving socket } \\
\text { - } \quad 448,000 \text { toe of annual energy conservation }\end{array}$ \\
\hline $\begin{array}{l}\text { Heat metering } \\
\text { and energy } \\
\text { efficiency } \\
\text { retrofit projects } \\
\text { for existing } \\
\text { buildings }\end{array}$ & $\begin{array}{l}\text { Heat metering upgrade and } \\
\text { energy efficiency envelope } \\
\text { retrofits in northern China }\end{array}$ & $\begin{array}{l}\text { - } 100 \text { million } \mathrm{m}^{2} \text { heat metering retrofit for public } \\
\text { buildings } \\
\text { - } 30 \text { million } \mathrm{m}^{2} \text { building envelope energy } \\
\text { efficiency retrofit } \\
\text { - } 10500 \mathrm{MW} \text { energy efficient upgrade for heating } \\
\text { - } \quad 0.91 \text { Mtoe of annual energy conservation } \\
\end{array}$ \\
\hline $\begin{array}{l}\text { Building } \\
\text { renewable } \\
\text { energy } \\
\text { application }\end{array}$ & $\begin{array}{l}\text { Promotion of renewable energy } \\
\text { applications in public buildings }\end{array}$ & $\begin{array}{l}\text { - } 1,000 \text { solar domestic hot water system projects } \\
\text { with } 200,000 \mathrm{~m}^{2} \text { solar collector area } \\
\text { - } 100 \text { solar heating projects with } 1 \text { million } \mathrm{m}^{2} \\
\text { heating area }\end{array}$ \\
\hline
\end{tabular}




\begin{tabular}{|l|l|l|}
\hline projects & $\bullet \begin{array}{l}1,000 \text { solar PV projects with 50+ MW capacity } \\
\text { and } 60 \text { million KWh annual power generation }\end{array}$ \\
& & $\begin{array}{l}1,000 \text { ground source heat pump projects with } 50 \\
\text { million } \mathrm{m}^{2} \text { in heating/cooling area }\end{array}$ \\
& & $\begin{array}{l}140,000 \text { toe of annual energy conservation } \\
\text { 2\% of total energy use is from new and } \\
\text { renewable energy (voluntary) }\end{array}$ \\
\hline
\end{tabular}

Source: (GOA, 2011).

\section{Energy performance contracts in public and large commercial buildings Project Financing for Pubic Building Retrofits}

In its $12^{\text {th }} F Y P$, the Chinese government has highlighted the importance of market mechanisms and energy performance contracting in energy-efficiency retrofits of public buildings (GOA, 2011). The national government aims to establish an energy-efficiency fund for public building retrofit and develop incentives to encourage energy-efficiency retrofits in public buildings. In particular, the Chinese government plans to improve the existing financial subsidies for ESCOs and develop mechanisms and incentives helping involve ESCOs in energy-efficiency retrofits of public buildings.

Currently, there are three major mechanisms to finance energy-efficiency retrofits in public buildings. The first one is that the national, province, and local governments provide funds for retrofits. From 20062010, the central government has invested 500 million yuan in public building retrofits and renovated the floorspace of over 2 million $\mathrm{m}^{2}$. Meanwhile, province and city governments also provide financial support for pubic building retrofits. For example, the Beijing government allocated special funds for energyefficiency retrofits in public buildings. The second approach is self-financing, which means that the owner or developer of the public building needs to pay for the retrofit himself.

The third financing approach is energy performance contracting, under which ESCOs conduct energyefficiency retrofits in a project in which the project savings cover the repayment costs, so the public institution does not need to invest its own capital. Their services normally include energy audit, project design, arrangement of project finance, equipment purchase, installation, and commissioning, operation and maintenance, and measurement and verification. In countries that that have significant ESCO markets such as the U.S., Germany, and Austria, the market often orients towards the public sector. Focusing on the public sector and large commercial buildings might reduce the associated risks in the ESCO business, and there is a great potential to use ESCOs in energy-efficiency retrofits in the public sector in China.

\section{ESCOs in the Chinese Market}

China's ESCO industry has grown exponentially in the past decade. From 2003 to 2010, the annual investment in energy performance contracting in China has increased from 100 million dollars to 4.25 billion dollars; the market grew over 40 times in 8 years (EMCA, 2011; Sun et al., 2011). One of the main drivers for the growth is the high demand for energy efficiency projects, spurred by China's effort of reducing energy use per unit GDP by 20\% during 2006-2010. The strong growth is expected to continue in the next few years, as NDRC issued the regulation providing financial subsidies for ESCOs.

One distinct feature of ESCO projects is that projects in the buildings sector tend to be small. According to surveys of the Energy Management Company Association (EMCA) during 2007-2009, energy 
performance contracting projects in China are equally divided between buildings and industry sector, but the capital cost of industrial projects is three times bigger than that in buildings (Figure 19). The typical investment in buildings is small and has a short payback time. Based on ERI's survey of 76 ESCOs, most of their projects have payback times of three years and the major technologies are renovation of HVAC system in public and large commercial buildings, boiler and heating system upgrade, and lighting (Figure 20).
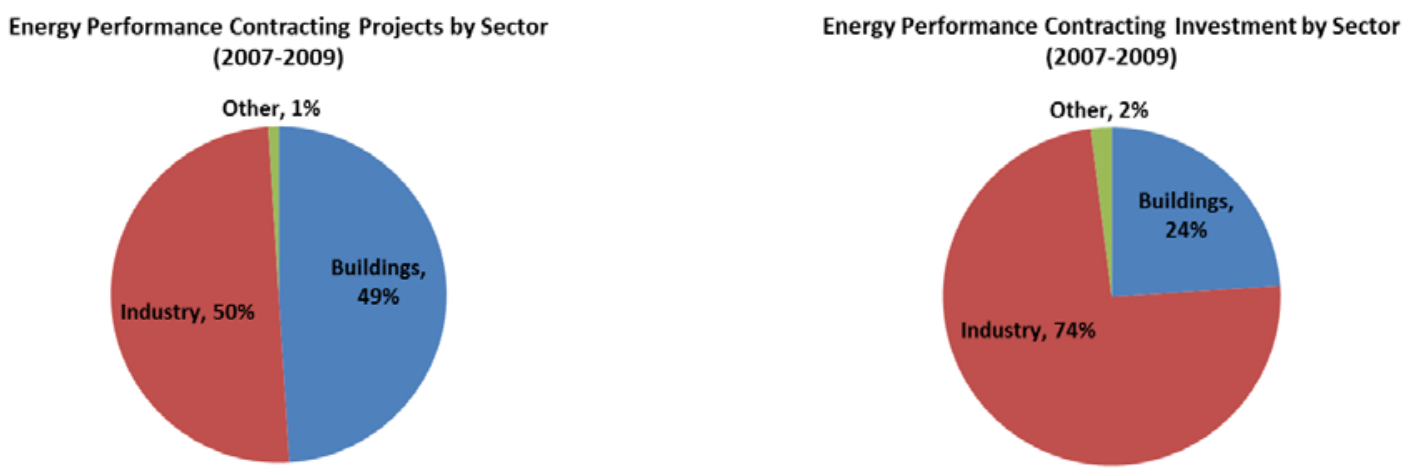

Figure 19 Energy performance contracting project type (left) and investment (right)

Source: (Sun et al., 2011).

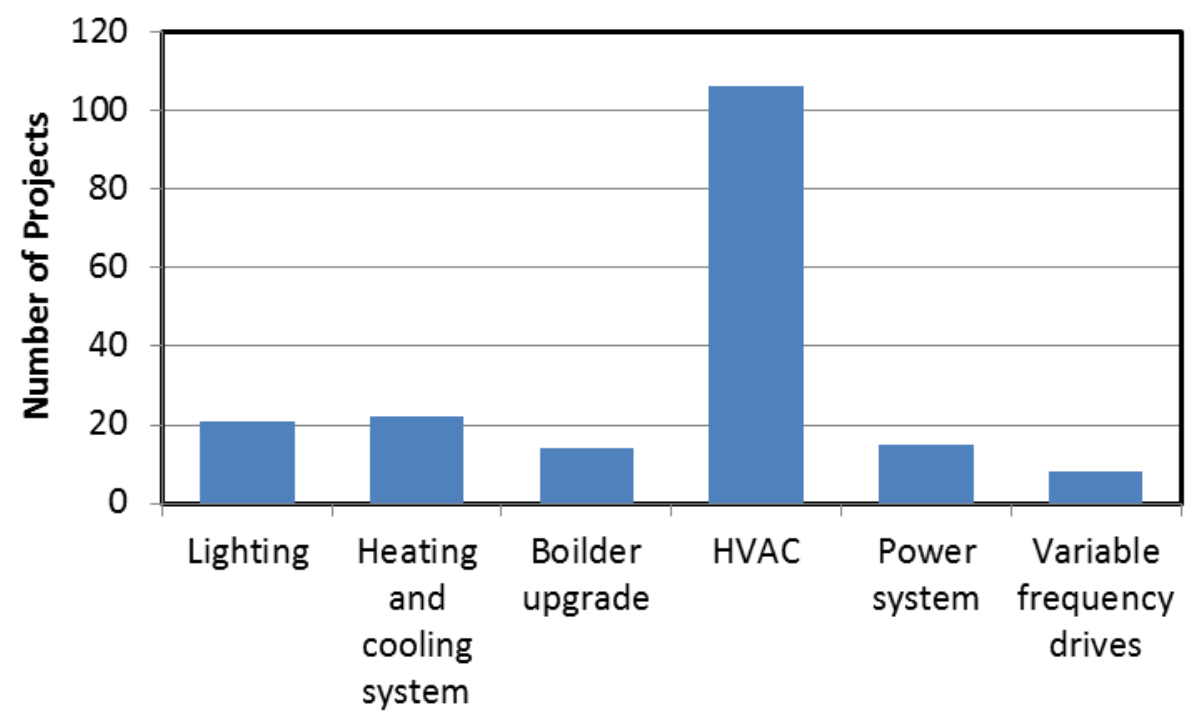

Figure 20 Technologies used by ESCOs in energy-efficiency retrofits of public and large commercial buildings

Source: (ERI, 2009).

Another feature of the Chinese market is that ESCOs in China are often small. China had over 900 ESCOs by the end of 2010, and over half of them were registered with EMCA. The average capital of EMCA-registered ESCOs was 27.8 million yuan in 2009, but there is great variation in company size. 
Nearly half of EMCA-registered ESCOs have less than 5 million yuan of capital (Figure 21) and only 18 of these ESCOs have capital of over 100 million yuan (Sun et al., 2011).

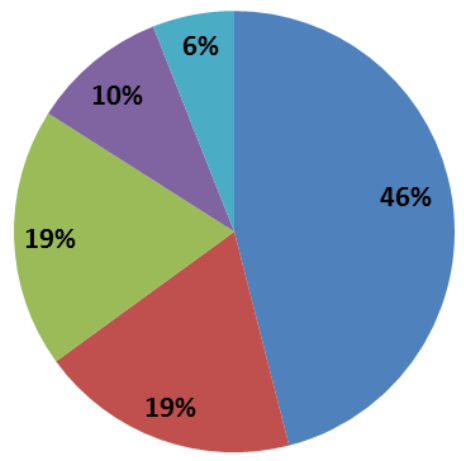

$$
\begin{aligned}
& \square<5 \text { million yuan } \\
& \square \text { 5-10 million yuan } \\
& =10-40 \text { million yuan } \\
& \square \text { 40-100 million yuan } \\
& \square>100 \text { million yuan }
\end{aligned}
$$

Figure 21 Registered capital of EMCA-member ESCOs (2009)

Source: (EMCA, 2011; Sun et al., 2011).

\section{Company Structures of ESCOs in China}

Successful ESCOs normally have relatively strong finances, broad technical skills and capability, and skills in project management. However, very few ESCOs in China have all these features and most of them only excel in one of the areas and their strengths are also strongly linked with their development paths. Most new ESCOs entered the business in China by selling their own technologies. Some of the new entrants are subsidiaries of energy efficient equipment providers that look for new ways to expand their market shares. The technology-based companies often face the challenge in project financing and mitigating financial risks. In addition, as most technology-based ESCOs start with their own patented technologies and tend to focus on a few technical areas, they may face the issue of sustainable growth when competition comes.

Some ESCOs evolved from local energy conservation centers. These centers, supported by the government, often provide energy conservation services for the local government and stakeholders and have the capacity to do energy audits and project consulting. These centers gained experience in energy performance contracting as the market evolves and started to work as ESCOs. Similar to the technologybased companies, energy conservation centers also face financial risks.

In recent years, an increasing number of large firms and financial institutions with strong financial support have started doing energy performance contracting or have established ESCO subsidiaries. For example, the China Energy Conservation and Environmental Protection Group has its subsidiary, the Consultation Company, which operates as an ESCO and provides assessment services for energy conservation projects for the national and local governments. Far East Horizon, a company providing financial services, is forming its own ESCO after providing project financing for ESCOs in the past few years. ESCOs backed by large firms or financial institutions have competitive advantage in project financing and financial management, but they also need to form a solid technical team in order to succeed in the ESCO industry. 
As the development and history of ESCOs differ largely, the shareholding structures also vary. The majority of ESCOs in China are joint-stock companies with a mix of private and public shareholders. In this situation, the local governments or state-owned companies often play a substantial role in company management and decision-making, and the state participation may also affect the type of ESCO projects. There are a significant number of privately owned ESCOs, but these companies often partner with stateowned companies in energy performance contracting projects to secure financing and leverage resources. There are also a few state-owned ESCOs, but the share is very small.

\section{Business Models for ESCOs}

In general, there are three common models used by ESCOs in China: shared savings, guaranteed savings, and the energy management outsourcing model or chauffer model. The shared savings model is the dominant model for ESCOs in China. In this model, the ESCO signs a financial contract with a financial institutions and a service agreement with the client. In addition to performance risk, the ESCO will take the financial risk that the client will not pay the service fees. The ESCO and the client share the value of the energy savings and the division of energy savings will be written in the contract. However, it requires a clearly written contract terms about how benefits will be shared and adjusted based on factors such as climate and occupancy, and it also requires clear protocols in measurement and verification. In addition, such contractual arrangements may raise capital requirement problems for ESCO because ESCO will become too indebted and a high debt-to-equity may lower its credit ratings to the lender.

In the guaranteed savings model, the ESCO guarantees a certain level of energy savings. If savings exceed this target, the client pockets the difference. If savings are less than expected, the ESCO receives a smaller payment. The benefits of this system are that the cash flow is stable and either to plan, both for the ESCO and for the client. Also, the potential additional cost savings are an incentive to customers.

In the chauffage model, the client pays an ongoing management fee to the ESCOs, and ESCO maintains and operates the client's energy system and takes on the responsibility of providing the improved level of energy service for a reduced bill. The more efficiently and cheaply it can do this, the greater its earnings. Compared to shared and guaranteed savings models, the chauffage model has long contract period, which is normally longer than 10 years in the Chinese market (ECONOLER, 2011; IFC, 2012). Chauffage contracts are very useful where the customer wants to outsource facility services and investment.

In general, the shared savings model is the most popular model on the Chinese market. In addition, the shared-saving model normally has a relatively short contract period, with an average contract period of 4.5 years; in the Chinese market, some shared savings contracts are usually three years or less (EMCA, 2011; Sun et al., 2011). Appendix C is an example of using shared-saving model in energy-efficiency retrofits of public buildings. 

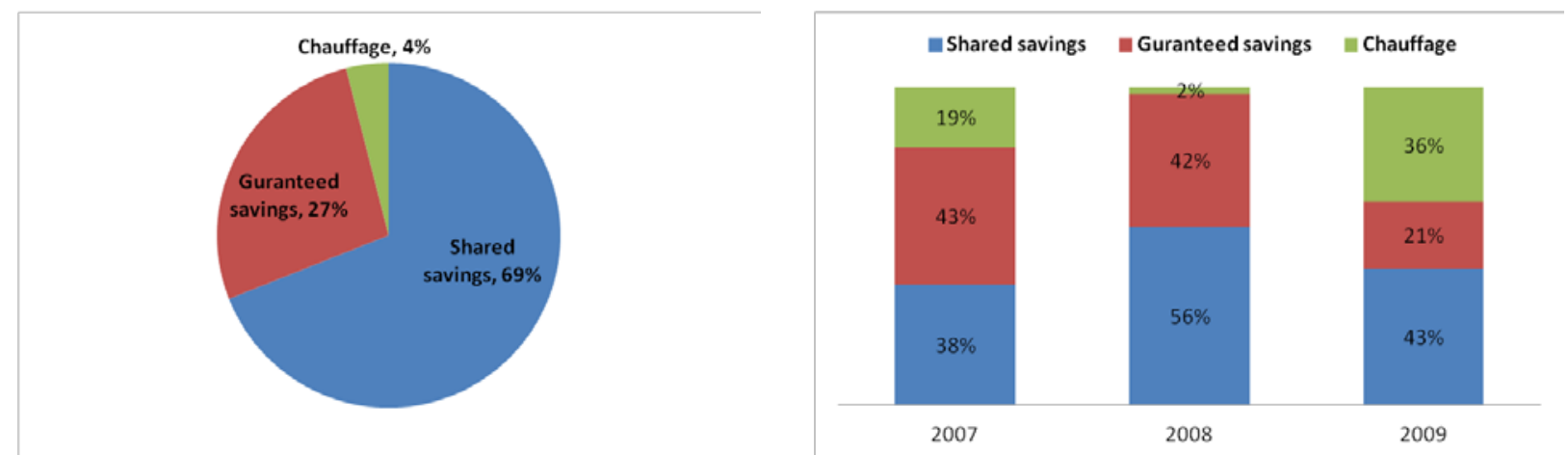

Figure 22 Share of Chinese energy performance contracts by project (left, 2007-2009) and by investment (right)

Source: (EMCA, 2011; Sun et al., 2011).

The chauffage model, in contrast, is not commonly used in energy-efficiency retrofits, but is always associated with large investment as the project tends to have long contract period and adopt comprehensive technologies. The chauffage model is normally used in large commercial and public buildings such as hospital and hotel and the popularity of the chauffage model has been increasing in recent years. Appendix D illustrates a case applying the chauffage model in building energy retrofits.

\section{Opportunities and Challenges}

Although the domestic policy climate supports the development of China's ESCO industry, there are still several barriers impending ESCO development in the buildings sector. There is a distinct disconnect between capital and projects. Most ESCOs are small and have limited capital. Banks and big companies are very cautious of lending to small clients or investing in small projects. In addition, funds and firms in the private market lack expertise and experience in the ESCO industry. Unfamiliar risk profiles of energy users prevent financing from being extended or require high collateral, but ESCOs in general lack assets that could serve as collateral. The gap between capital and projects emerged as the main obstacle to the development of ESCO industry.

In addition, energy savings is hard to quantify and evaluate. In general, problems exist in defining baseline, calculating monthly savings, modeling dynamic change, estimating savings other than energy, communicating in accounting system and contracting system, and evaluating payback period. Therefore, most ESCOs chose safe and "tangible" approaches. Installing energy efficient lamps is the most common example as both parties could calculate energy savings based on the efficiency of the bulb and avoid ambiguous and disputed process of M\&V Therefore, installing equipment or providing appliances prevails in China's ESCO industry. In addition, lack of a well-developed M\&V system generated a more severe problem: credibility of energy efficient improvements and mutual trust between ESCOs and clients, or sometimes between ESCO and financial institutions. This problem is exacerbated with shard savings contracts, where energy savings are not quantified and pre-defined in the contract, and in such contracts, disputes often occur when ESCO collects payback through savings. It is alleged that uncollectible debt of some ESCOs reaches as high as 50\% of its revenue (Yu, 2010).

However, the market is changing and there are increasing opportunities for ESCOs involved in building retrofits and in achieving high-quality investment in buildings project. Adequate financing, favorable 
legal and contractual environment, robust certification schemes and protocols for evaluation, and government support are critical for the development of ESCOs in China and large-scale application in buildings (UNDP, 2010).

The Chinese government is actively promoting building energy efficiency. As discussed earlier, the government has set stringent standards and goals for building energy efficiency and green buildings, which will encourage the development of the ESCO industry. In addition, the construction and real estate industry in China are in tune to government's actions and policies, which will lead more building energyefficiency projects in China and create a large market for ESCOs.

The Chinese government also has a strong commitment to promoting the ESCO industry itself. In 2010, the Chinese government adopted favorable national tax legislation for ESCOs that implement energyefficiency projects on a paid-from-savings basis. These incentives include

- Exempting ESCOs from the business tax and value added tax on qualified projects;

- Exempting qualified ESCO income from income taxes (100\% for the first three years and 50\% for the next three years);

- Allowing clients to deduct expenses for energy saving services before taxes;

- Treating assets transferred to clients after the service period as fully depreciated for tax purposes,.

Some provincial and city governments also provide additional financial incentives and subsidies for ESCOs, which together would help alleviate the financing issues for some ESCOs. In addition, international organizations such as the World Bank have been supporting the growth of the Chinese ESCO industry for a decade and continue their support in capacity building and market awareness. This will help improve the market environment as well as enhance ESCO's capability of measurement and verification, energy audit, and providing comprehensive services.

\section{Conclusions}

China has experienced a construction boom in the last decade, which made it one of the largest building energy consumers in the world. China has also become the world's leading market for new constructions. With the dramatic increase in building stock and rapid urbanization, building energy consumption has already become one of the most critical issues for the Chinese government. The new leadership in China has issued a set of policies regarding building energy efficiency to accommodate the national goal of a $40-45 \%$ reduction in carbon intensity by 2020 relative to 2005 levels. These policies not only make the national and local governments focus on building energy efficiency, but also create a huge market for companies working on building energy efficiency.

Building energy codes have significantly increased the demand for energy efficient building products and materials in the past three decades, and in the following years, it is still going to be the most important driver of the market for building energy efficiency. The Chinese securities companies estimated that stringent building energy codes and robust compliance may attract investment of 100-150 billion yuan in building energy efficiency by 2015. Beyond building energy codes, there are also voluntary programs and incentives that will help further expand the market for building energy efficiency. In particular, the demand for insulation materials, energy efficient windows, energy efficient lighting, and commercial 
HVAC system will grow rapidly. Related products such as air sealing products will also grow as energyefficiency requirements enhance in China.

Existing buildings also present vast opportunities in building energy efficiency improvement. As residential retrofit is mandatory and retrofit of public buildings are promoted by multiple government agencies, there are also demand for market mechanisms of conducting energy-efficiency retrofits. It is expected that the application of ESCOs in buildings sector will keep growing, so does ESCOs' investment in buildings.

Major policies encourage the investment in building energy efficiency and help the market grow. While there are significant opportunities in the Chinese market, the capacity and reality still poses challenges for companies working on it. Understanding the barriers and competitive landscape is also important for companies that want to enter and expand in the Chinese market for building energy efficiency.

\section{Acknowledgments}

The authors are grateful for research support provided by the Office of Energy Efficiency and Renewable Energy of the U.S. Department of Energy and the Global Technology Strategy Program. The authors acknowledge long-term support for the development of the Global Change Assessment Model (GCAM) from the Integrated Assessment Research Program in the Office of Science of the U.S. Department of Energy. The Pacific Northwest National Laboratory is operated for the U.S. Department of Energy by the Battelle Memorial Institute under contract DE-AC05-76RL01830. The views and opinions expressed in this paper are those of the authors alone. 


\section{References}

AQSIQ. (1999). Limited values of energy efficiency and evaluating values of energy conservation of ballasts for tubular fluorescent lamps (GB 17896-1999). Beijing: General Administration of Quality Supervision, Inspection and Quarantine.

AQSIQ. (2003a). Limited Values of Energy Efficiency and Evaluating Values of Energy Conservation for Single-Capped Fluorescent Lamps (GB19415-2003). Beijing: General Administration of Quality Supervision, Inspection and Quarantine.

AQSIQ. (2003b). Limited Values of Energy Efficiency and Rating Criteria of Double-capped Fluorescent Lamps for General Lighting Service (GB 19043-2003). Beijing: General Administration of Quality Supervision, Inspection and Quarantine.

AQSIQ. (2003c). Minimum Allowable Values of Energy Efficiency and Energy Efficiency Grades of Self-Ballasted Fluorescent Lamps for General Lighting Service (GB 19044-2003). Beijing: General Administration of Quality Supervision, Inspection and Quarantine.

AQSIQ. (2004a). Limited Values of Energy Efficiency and Evaluating Values of Energy Conservation of Ballast for High-Pressure Sodium Lamps (GB 19574-2004). Beijing: General Administration of Quality Supervision, Inspection and Quarantine.

AQSIQ. (2004b). Limited Values of Energy Efficiency and Rating Criteria for High-pressure Sodium Vapour Lamps (GB 19573-2004). Beijing: General Administration of Quality Supervision, Inspection and Quarantine.

AQSIQ. (2006a). The Minimum Allowable Values of Energy Efficiency and the Energy Efficiency Grades for Ballast of Metal-Halide Lamps (GB 20053-2006). Beijing: General Administration of Quality Supervision, Inspection and Quarantine.

AQSIQ. (2006b). The Minimum Allowable Values of Energy Efficiency and the Energy Efficiency Grades for Metal-Halide Lamps (GB 20054-2006). Beijing: General Administration of Quality Supervision, Inspection and Quarantine.

Beijing COHURD. (2010). Notice on Promoting the Energy Efficinecy Labels for Doors and Windows. Retrieved from http://www.bjjs.gov.cn/publish/portal0/tab662/info60944.htm.

Beijing Municipal Commission of City Administration and Environment. (2011). Beijing's 12th FYP for Building Energy Efficiency. Retrieved from http://www.mofcom.gov.cn/article/zt_shangwubu/lanmutwo/201109/20110907738626.shtml.

Centre for Strategic Economic Studies, V. U., Australia. (2010). Identifying Policies and Implementation Strategies for Improving Energy Efficiency, Case Study 2: Energy Efficient Air Conditioners. Melbourne: Centre for Strategic Economic Studies, Victoria University, Australia.

Chen, Y., Yang, G., Sweeney, S., and Feng, Y. (2010). Household biogas use in rural China: A study of opportunities and constraints. Renewable and Sustainable Energy Reviews, 14(1), 545-549.

China Daily. (2012, May 8). Air Conditioner Sales Cool Down. China.org.cn, from http://www.china.org.cn/business/2012-05/08/content_25327321.htm. 
China Real Estate Business. (2012, December 12). Green the Building by Energy-efficient Doors and Windows. Sina Real Estate Channel, from http://news.dichan.sina.com.cn/2012/12/13/614989.html.

Cinda Securities. (2013). Market opportunities under Energy Convervation Special Plan during Twelfth Five-Year Plan Period. Beijing: Cinda Securities Co,. Ltd.

CITIC Securities. (2013a). Energy Conservation and Urbanization in China. Beijing, China: CITIC Securities Companies Limited.

CITIC Securities. (2013b). Industry Deep Report: Building Energy Efficiency. Shanghai: CITIC Securities Co,. Ltd,.

Crea, J. (2013). Heading Back to China. Retrieved June 20, 2013, from http://www.usgbc.org/articles/heading-back-china.

Deneen, M. A., Gross, A. C., and Mapes, J. L. (2010). Indoor Climate Control: the Global Demand for Heating, Ventilating, and Air-conditioning Equipment. Business Economics, 126-134.

Du, M. (2013). Building Energy Efficiency in Shanghai. In Q. Shi (Ed.).

ECONOLER. (2011). IFC Energy Service Company Market Analysis. Quebec, Canada: ECONOLER.

EMCA. (2011). ESCO Development in China. Paper presented at the U.S.-China Energy Efficiency Forum. Retrieved from http://www1.eere.energy.gov/office_eere/pdfs/session_1_financing_track_zhao_ming_en.pdf.

Eom, J., Clarke, L., Kim, S. H., Kyle, P., and Patel, P. (2012). China's building energy demand: Longterm implications from a detailed assessment. Energy, 46(1), 405-419.

ERI. (2009). Market Survey Report on Current Financing Mechanism to Promote Existing Buildings Energy Efficiency in China. Beijing, China: Energy Research Institute of National Development and Reform Commission.

Evans, M., Yu, S., Song, B., Deng, Q., Liu, J., and Delgado, A. (2013). Building Energy Efficiency in Rural China. Energy Policy, 10.1016/j.enpol.2013.06.040.

Freedonia. (2013). Insulation in China to 2016 Cleveland, OH: Freedonia Group.

Freedonia Group. (2011). Windows and Doors in China: Industry Study with Forecasts for 2014-2019: Freedonia Group.

Frost \& Sullivan. (2012). China HVAC Market Analysis. Shanghai: Frost \& Sullivan.

Geng, N. (2013). All New Buildings in Bejing Will be One-Star Green Buildings Retrieved July 23, 2013, from http://news.xinhuanet.com/local/2013-03/30/c_124523402.htm.

Glass, L. N. (2011). IPO Prospectus of Luoyang North Glass Technology Co., Ltd, . Beijing, China: Luoyang North Glass Technology Co., Ltd.

GOA. (2011). 12th FYP for Energy Conservation in Public Buildings. Retrieved from http://www.ggj.gov.cn/gwfb/201110/t20111010 275650.htm. 
Gold Mantis Construction Decoration Co., L. (2010). Feasibility Report on Raised Fund from Private Placement. Suzhou: Gold Mantis Construction Decoration Co., Ltd.

Guodu Securities. (2013). MDI Industry Analysis. Beijing: Guodu Securities Co,. Ltd.

Huang, J., and Deringer, J. (2007). Status of Energy Efficient Building Codes in Asia. Hong Kong, China: The Asia Business Council.

HVAC China. (2013). Central Air Conditioner Industry Development Report 2012. Beijing: Journal of HV\&AC.

IEA. (2011). Key World Energy Statistics. Paris, France: International Energy Agency.

IEA. (2012a). 2009 Energy Balances (I. E. Agency, Trans.). Paris, France: International Energy Agency.

IEA. (2012b). Energy Balances of Non-OECD Countries (2012 edition). In IEA (Ed.). Paris, France.

IFC. (2012). China Energy Service Company (ESCO) Market Study. Beijing, China: International Finance Corporation.

International SSL Alliance. (2013). Global Solid State Lighting Outlook. Beijing: International SSL Alliance.

Li, B., and Yao, R. (2009). Urbanisation and its impact on building energy consumption and efficiency in China. [doi: 10.1016/j.renene.2009.02.015]. Renewable Energy, 34(9), 1994-1998.

Li, D. (2009). Fiscal and tax policy support for energy efficiency retrofit for existing. Energy Policy, 2113-2118.

Li, S. (2011). Study on Suitableness of Internal Wall Insulation for Civil Buildings in Hot Summer Cold Winter Zone. Hangzhou: Zhejiang University, China.

Liu, R. (2013). Targeted Vertical Solutions to Drive Growth in Chinese Building Automation Market. from http://www.imsresearch.com/pressrelease/targeted_vertical_solutions_to_drive_growth_in_chinese_building_automation_market\&c at_id=206\&type=LatestResearch.

McKinsey \& Company. (2012). Lighting the Way: Perspective on Global Lighting Market 2012: McKinsey \& Company.

MIIT. (2011). Development Guideline for Building Material Industry in China During the 12th Five-Year Plan Period. Retrieved from http://www.miit.gov.cn/n11293472/n11295125/n11299605/n14335392.files/n14335391.pdf.

Min, G., Mills, E., and Zhang, Q. (1995). Energy Efficient Lighting in China: Problems and Prospects. Energy Policy, 77-83.

MOF. (2007). Provisional Measures on Administration of Energy Efficient and Heat Metering Retrofit for Existing Buildings in Northern China. Retrieved from http://www.mohurd.gov.cn/zcfg/xgbwgz/200712/t20071228_159878.html. 
MOF. (2012). Accelerating the Development of Green Buildings in China. Retrieved from http://jjs.mof.gov.cn/zhengwuxinxi/tongzhigonggao/201205/t20120507_648962.html.

MOF, and MOHURD. (2011). Notification on Further Implementation of Energy-efficiency Retrofits in Public Buildings. Retrieved from http://www.gov.cn/zwgk/2011-05/11/content_1861716.htm.

MOHURD. (1995). Energy Conservation Design Standard for New Heating Residential Buildings (JGJ 26-95). Beijing: Ministry of Housing and Urban-Rural Development.

MOHURD. (2001). Design Standard for Energy Efficiency of Residential Buildings in Hot Summer and Cold Winter Zone (JGJ 124-2001). Beijing: MOHURD.

MOHURD. (2003). Design Standard for Energy Efficiency of Residential Buildings in Hot Summer and Warm Winter Zone (JGJ 75-2003). Beijing: MOHURD.

MOHURD. (2006). Administration of Pilot Projects of Energy-efficient Label for Doors and Windows. Retrieved from http://www.windowlabel.cn/WebSiteW/News/ShowInfo.aspx?ArticleGuid=b02b1cb4-88fa-45d08a39-08257b871faa.

MOHURD. (2010a). Design Standard for Energy Efficiency of Residential Buildings in Hot Summer and Cold Winter Zone (JGJ 134-2010). Beijing: Ministry of Housing and Urban-Rural Development.

MOHURD. (2010b). Design Standard for Energy Efficiency of Residential Buildings in Severe Cold and Cold Zone (JGJ 26-2010). In MOHURD (Ed.). Beijing: Ministry of Housing and Urban-Rural Development.

MOHURD. (2010c). Design Standard for Energy Efficiency of Residential Buildings in Severe Cold and Cold Zone (JGJ 26-2010). In MOHURD (Ed.). Beijing.

MOHURD. (2010d). Notice on Further Promotion of Energy-efficient Label for Doors and Windows. Retrieved from http://www.gov.cn/zwgk/2010-07/13/content_1652832.htm.

MOHURD. (2011a). Sino-Germany Technology Cooperation Program: China Existing Building Energy Efficiency Retrofit Program. Retrieved September 12, 2013, from http://www.mohurd.gov.cn/zxydt/201110/t20111012 206559.html.

MOHURD. (2011b). Special Guideline for Building Energy Conservation during Twelfth Five-Year Plan Period. Retrieved from http://www.gov.cn/zwgk/2012-05/31/content_2149889.htm.

MOHURD. (2012). Energy Conservation Special Plan during Twelfth Five-Year Plan Period.

MOHURD. (2013a). Design Standard for Energy Efficiency of Rural Residential Buildings (Vol. GB50824-2013). Beijing, China: Ministry of Housing and Urban-Rural Development.

MOHURD, NDRC, and MOF. (2012). Notification on Expanding the Retrofits in Rural Homes in 2012 (in Chinese). Retrieved from http://www.mohurd.gov.cn/zcfg/jsbwj_0/jsbwjczghyjs/201207/t20120706_210523.html.

MOHURD, NDRC, MOF, and AQSIQ. (2010). Advise on Further Improvement of Heat Metering Reform. Retrieved from http://www.gov.cn/gzdt/2010-03/17/content_1557963.htm. 
MOHURD, N. (2013b). Green Building Action Plan.

MPS. (2011). Notice on Further Clarification on Fire Inspection Requirements Related to the Management of Insulation Materials for Civil Buildings. Retrieved from http://119.china.com.cn/qwxx/txt/2011-03/16/content_4066790.htm.

MPS. (2012). Notice on Fire Inspection Requirements Related to the Management of Insulation Materials for Civil Buildings Retrieved from http://www.119.gov.cn/xiaofang/zywj/19999.htm.

NBSC. (1999). Comprehensive Statistical Data and Materials on 50 Years of New China Beijing, China: China Statistics Press.

NBSC. (2006). China Statistical Yearbook 2006. Beijing, China: National Bureau of Statistics of China.

NBSC. (2010). China Statistical Yearbook 2010. Beijing, China: National Bureau of Statistics of China.

NBSC. (2012). China Statistical Yearbook 2012. Beijing, China: National Bureau of Statistics of China.

NDRC. (2007). Policies on Software Industry and IC industry Development Promotion.

NDRC, and MOF. (2008). Interim Management Measures for High Efficiency Lighting Products Promotion Financial Subsidies. Retrieved from http://www.gov.cn/gzdt/200801/21/content_864281.htm.

NDRC, M. (2008). Interim Management Measures for High Efficiency Lighting Products Promotion Financial Subsidies.

NDRC, M., MIIT, MOF, MOHURD, AQSIQ. (2009). Solid State Lighting Energy Conservation Industry Development Advice.

NDRC, M., MIIT, MOF, MOHURD, AQSIQ. (2012). Guideline of Energy Efficient Semiconductor Lighting Industry.

NDRC, M., The People's Bank of China, State Administration of Taxation. (2010). Advice on Accelerate the Implementation of Energy Management Contract and Promotion the Development of Energy Conservation Industry.

Office of State Council. (2007). Notice on Establishing the Compulsory Governmental Procurement Mechanisms for Energy Conservation Products. Retrieved from http://www.gov.cn/zwgk/200708/06/content_707549.htm.

Orient Securities. (2013). Energy Conservation and Smart Buildings. Beijing, China: Orient Securities.

PR Newswire. (2013, March 26). Frost \& Sullivan: China's Air Conditioner Market: Room AC Declining, HVAC Booming. from http://www.prnewswire.com/news-releases/frost--sullivan-chinas-airconditioner-market-room-ac-declining-hvac-booming-144180825.html.

Qiu, B. (2010). Strengthen the Efforts of Heat Metering Reform and Complete the Building Energy Conservation Goal. Retrieved from http://www.china-heating.org.cn/banjiboke/1375.jhtml.

Research and Markets. (2012). China Thermal Insulation Material Industry Report: Research and Markets. 
ResearchInChina. (2010). China Low-e Glass Industry Analysis Report 2010.

Security, M. M. o. P. (2009). Interim Provisions on Fireproof Standards of External Thermal Insulation System and Exterior for Civil Buildings.

Shui, B., Evans, M., Lin, H., Liu, B., Song, B., and Somasundaram, S. (2009). Country Report on Building Energy Codes in China. Richland, WA: Pacific Northwest National Laboratory.

Sinolink Securities. (2013). Green Building Deep Analysis. Beijing: Sinolink Securities Co,. Ltd.

Sun, X., Zhu, L., and Taylor, B. (2011). China's ESCO Industry: Saving More Energy Everyday Through the Market. Retrieved August 1, 2013: http://ryanschuchard.files.wordpress.com/2011/06/chinasesco-industry-2010.pdf.

THUBERC. (2011). 2011 Annual Report on China Building Energy Efficiency. Beijing, China: China Architecture and Building Press.

Trefis (Producer). (2013, April 09) China's Urbanization Is Driving Johnson Controls' HVAC Growth. Forbes. retrieved from http://www.forbes.com/sites/greatspeculations/2013/04/09/chinasurbanization-is-driving-johnson-controls-hvac-growth/.

UBS Investment Research. (2012). China Glass Industry Outlook. Shanghai: UBS Investment Research.

UNDP. (2010). Promoting Energy Efficiency in Buildings: Lessons Learned From International Experience. New York, USA: United Nations Development Programme.

World Bank. (2011). World Development Indicators. Washington, D.C.: The World Bank.

Yu, S. (2010). Financing Models for Energy Efficiency Projects. Columbus, OH: Battelle Memorial Institute.

Yu, S., Eom, J., Evans, M., and Clarke, L. (2014a). A long-term, integrated impact assessment of alternative building energy code scenarios in China. Energy Policy, 67(0), 626-639.

Yu, S., Eom, J., Zhou, Y., Evans, M., and Clarke, L. (2014b). Scenarios of building energy demand for China with a detailed regional representation. Energy(0).

Zhao, J., and Lou, F. (2013). Institutional Effect Analysis Comparing Energy Efficiency Retrofitting for Existing Residential Buildings Patterns in China. Paper presented at the 1st Annual International Interdisciplinary Conference, Azores.

Zhao, S. (Producer). (2013, June 20) Sina Real Estate Channel. Policy Review of China Building Thermal Insulation Materials. retrieved from http://news.dichan.sina.com.cn/2013/06/20/765976.html. 
Appendix A U-Value of Building Envelope in Current Building Energy Codes for Residential Buildings

\begin{tabular}{|c|c|c|c|c|c|c|c|c|c|}
\hline \multicolumn{10}{|c|}{ Maximum Heat Transfer Coefficient or U-factors Unit: watt/(m2*K) } \\
\hline & & \multirow[t]{2}{*}{ Roof } & \multirow[t]{2}{*}{ Exterior wall } & \multirow{2}{*}{$\begin{array}{c}\text { Overhead or } \\
\text { protruding floor that } \\
\text { contracts outdoor }\end{array}$} & \multirow{2}{*}{$\begin{array}{c}\text { Roof of nonheated } \\
\text { basements }\end{array}$} & \multicolumn{4}{|c|}{$\begin{array}{l}\text { Single-orientation exterior windows (including transparent } \\
\text { curtain walls) }\end{array}$} \\
\hline & & & & & & $\mathrm{WWR} \leq 0.2$ & $0.2<\mathrm{WWR} \leq 0.3$ & $0.3<\mathrm{WWR} \leq 0.4$ & $0.4<\mathrm{WWR} \leq 0.45$ \\
\hline \multirow{3}{*}{ Severe Cold Zone A } & Floor $\leq 3$ & 0.2 & 0.25 & 0.3 & 0.35 & 2 & 1.8 & 1.6 & 1.5 \\
\hline & $4 \leq$ Floor $\leq 8$ & 0.25 & 0.4 & 0.4 & 0.45 & 2.5 & 2 & 1.8 & 1.6 \\
\hline & Floor $\geq 9$ & 0.25 & 0.5 & 0.4 & 0.45 & 2.5 & 2.2 & 2 & 1.8 \\
\hline \multirow{3}{*}{ Severe Cold Zone B } & Floor $\leq 3$ & 0.25 & 0.3 & 0.3 & 0.35 & 2 & 1.8 & 1.6 & 1.5 \\
\hline & $4 \leq$ Floor $\leq 8$ & 0.3 & 0.45 & 0.45 & 0.5 & 2.5 & 2.2 & 1.9 & 1.7 \\
\hline & Floor $\geq 9$ & 0.3 & 0.55 & 0.45 & 0.5 & 2.5 & 2.2 & 2 & 1.8 \\
\hline \multirow{3}{*}{ Severe Cold Zone C } & Floor $\leq 3$ & 0.3 & 0.35 & 0.35 & 0.5 & 2 & 1.8 & 1.6 & 1.5 \\
\hline & $4 \leq$ Floor $\leq 8$ & 0.4 & 0.5 & 0.5 & 0.6 & 2.5 & 2.2 & 2 & 1.8 \\
\hline & Floor $\geq 9$ & 0.4 & 0.6 & 0.5 & 0.6 & 2.5 & 2.2 & 2 & 1.8 \\
\hline \multirow{3}{*}{ Cold Zone A } & Floor $\leq 3$ & 0.35 & 0.45 & 0.45 & 0.5 & 2.8 & 2.8 & 2 & 1.8 \\
\hline & $4 \leq$ Floor $\leq 8$ & 0.45 & 0.6 & 0.6 & 0.65 & 3.1 & 2.8 & 2.5 & 2 \\
\hline & Floor $\geq 9$ & 0.45 & 0.7 & 0.6 & 0.65 & 3.1 & 2.8 & 2.5 & 2.3 \\
\hline \multirow{3}{*}{ Cold Zone B } & Floor $\leq 3$ & 0.35 & 0.45 & 0.45 & 0.5 & 2.8 & 2.5 & 2 & 1.8 \\
\hline & $4 \leq$ Floor $\leq 8$ & 0.45 & 0.6 & 0.6 & 0.65 & 3.1 & 2.8 & 2.5 & 2 \\
\hline & Floor $\geq 9$ & 0.45 & 0.7 & 0.6 & 0.65 & 3.1 & 2.8 & 2.5 & 2.3 \\
\hline \multirow{2}{*}{ HSCW } & Floor $\leq 3$ & 0.5 & 0.8 & 1 & - & 4 & 3.2 & 2.8 & 2.5 \\
\hline & Floor $\geq 4$ & 0.8 & 1 & 1.5 & - & 4.7 & 4 & 3.2 & 2.8 \\
\hline \multirow{3}{*}{ HSWW } & $\mathrm{D} \geq 2.5$ & $0.4<\mathrm{U} \leq 0.9$ & $0.7<\mathrm{U} \leq 1.5$ & - & - & 6 & 5.5 & 5 & 4.5 \\
\hline & $\mathrm{D} \geq 2.8$ & - & $1.5<\mathrm{U} \leq 2.0$ & - & - & 4 & 3.5 & 3 & 2.5 \\
\hline & $\mathrm{D} \geq 3.0$ & - & $2.0<\mathrm{U} \leq 2.5$ & - & - & - & - & - & - \\
\hline
\end{tabular}

Sources: Design Standard for Energy Efficiency of Residential Buildings in Severe Cold and Cold Zones (JGJ 26-2010), Design Standard for Energy Efficiency of Residential Buildings in Hot Summer and Cold Winter Zones (JGJ 134-2010) and Design Standard for Energy Efficiency of Residential Buildings in Hot Summer and Warm Winter Zones (JGJ 75-2012), MOHURD.

Note:

1. The temperate climate zone currently implements energy codes for the HSWW zone.

2. Severe cold and cold zones are further divided by heating and cooling degree days; heating degree days decline and cooling degree days increase from subzones A to C. For example, severe cold zone A is the coldest. 
3. D: Index of Thermal inertia; WWR: Windows to Wall Ratio; HSCW: Hot Summer and Cold Winter Zones; HSWW: Hot Summer and Warm Winter Zones

4. The energy code for commercial buildings is currently under revision and the new version is expected to be released in 2014. We will develop an equivalent table for commercial buildings after the new code is issued. 


\section{Appendix B Building Material and Product Database Used in Code Compliance in China}

The Chinese code compliance software PKPM-Energy links with a database of energy efficient building materials and products. PKPM-Energy integrates technical design software (similar to AutoCAD) and building simulation, and is widely used by Chinese architects and developers to design buildings and check if buildings comply with energy code requirements. The Chinese government is also developing a catalog of green building materials and products; products in the catalog will be recommended for use in green or energy efficient buildings. This memo will briefly discuss the PKPM database for energy efficient building materials and the green building material catalog and provide information on how U.S. companies could benefit from these tools.

\section{PKPM Database for Energy Efficient Building Materials}

Chinese building energy codes have three compliance pathways: prescriptive, trade-off, and wholebuilding performance. Most Chinese architects and engineers use software packages to ensure compliance. PKPM-Energy, the energy efficiency analysis software based on the DOE-2 engine, is the most widely used software package for code compliance with around 70\% market share, followed by Tangent-BEC and THS-BECS. These software packages are developed by private institutes and companies and are fee-based.

PKPM-Energy supports the Chinese national building codes for urban residential buildings and public/commercial buildings as well as codes and standards of local authorities. For big cities like Beijing and Shanghai, local standards are more stringent than national codes and supersede national codes. In this case, PKPM-Energy will automatically apply the local standards to buildings. PKPM-energy first checks if the designed building meets the prescriptive requirements in the corresponding energy codes; if not, the software will apply the trade-off method to check compliance; if the building still does not comply with the code, the software will automatically apply the whole-building compliance approach and run building energy simulation. PKPM-Energy will then generate a document with detailed technical information and energy saving results that the designers can submit for plan review by code officials ${ }^{16}$.

PKPM-Energy links with a database of building products and materials. The default database contains general information of building materials, but does not include specific product information. For example, for walls, the information included in the default database are name (such as external wall, hot bridge, floor, doors, etc.), thickness, U-value, index of thermal inertia (D), and Solar Heat Gain Coefficient (SHGC) (Figure 1). For some regions, there is an extension database on building materials with specific information of building products and manufacturers, including product name, function, flame-retardant grade, manufacturer, thickness, U-value, and index of thermal inertia (Figure 2). The extension database is widely used by architects and designers as they can use it to easily access product information at the design stage. Architects and designers are not allowed to change the properties and information of the

\footnotetext{
${ }^{16}$ Chinese codes do not require using software to demonstrate and verify code compliance, and architects can choose other approaches to demonstrating compliance.
} 
existing product in the system, but in some regions they can manually add new materials to the database. The database is not exclusive to the Chinese companies and products of foreign companies can be added to the database when obtaining approval. For example, some foreign firms indicated that their insulation materials are included in the PKPM-Energy material database for Shanghai.

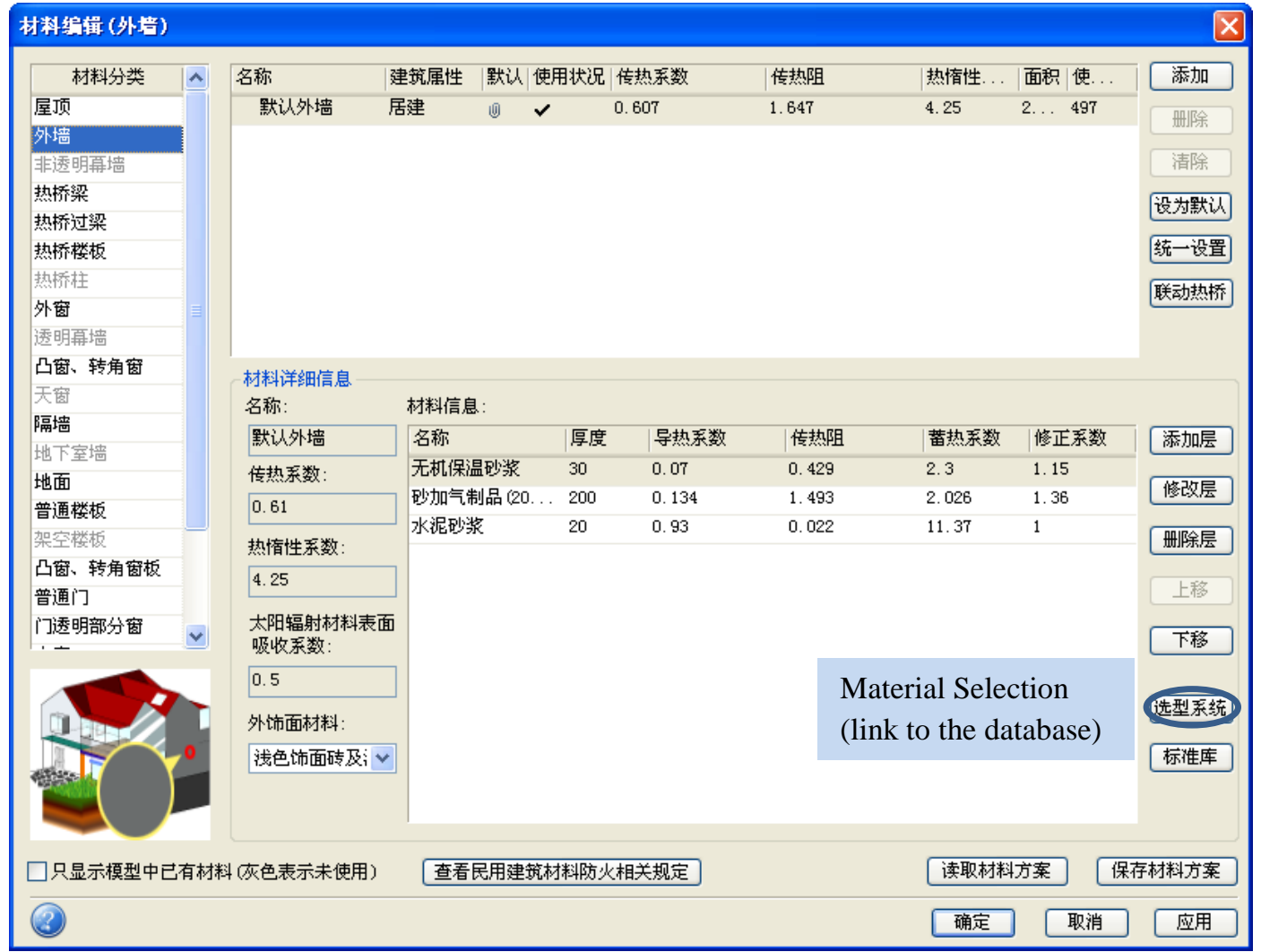

Figure 1: Editing building materials in PKPM-Energy 


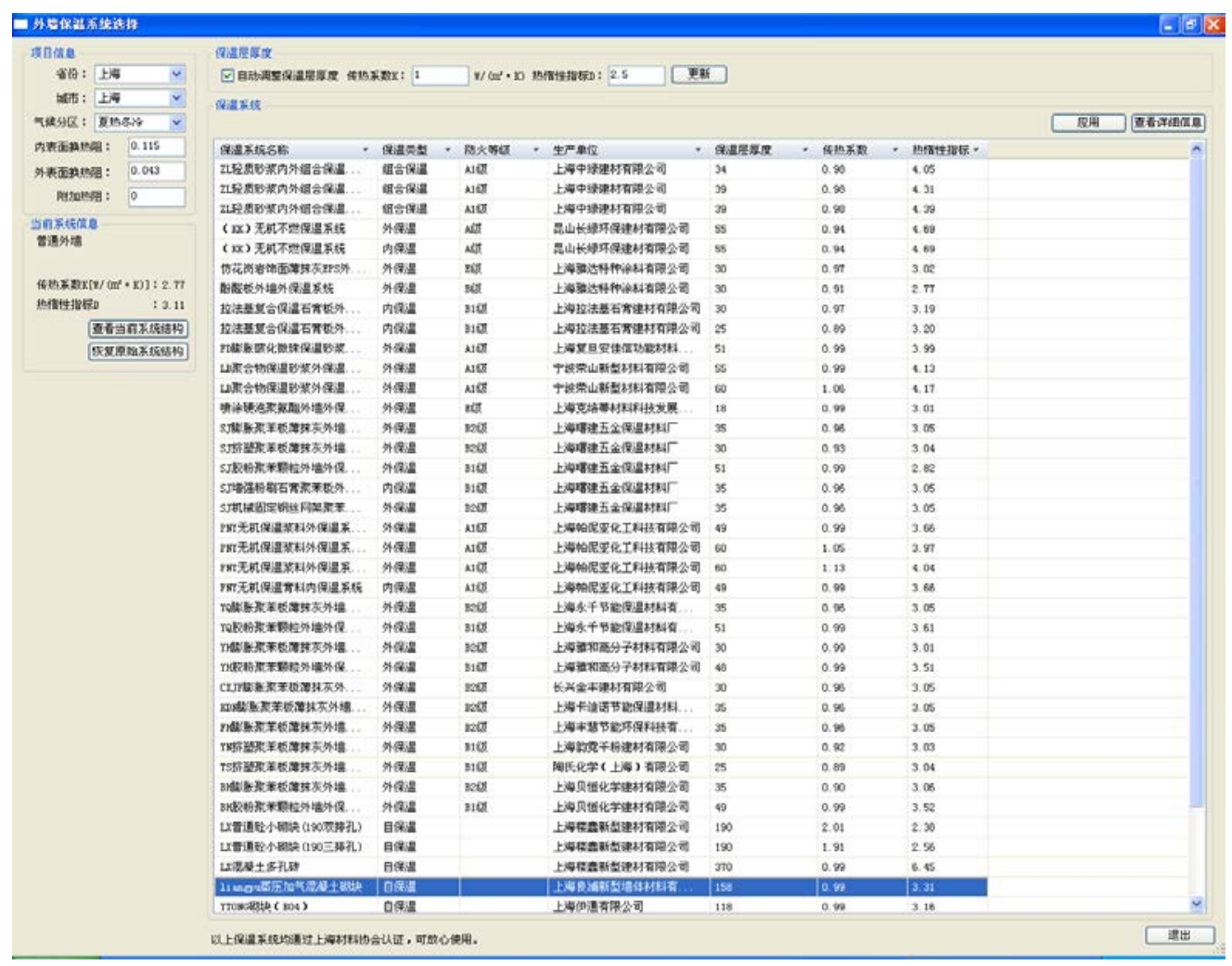

Figure 2: PKPM-Energy Building Materials Database

According to the PKPM-Energy development team, building materials in the PKPM-Energy database have been approved or certified by building material associations or the local construction quality supervision stations. To have a product included:

1. Manufacturers review the detailed instructions provided by PKPM developers on how to get into the database.

2. Fill out an application form describing the company and applicable product(s) and include product certifications and testing results certified by qualified testing labs. There is also an application fee.

3. Construction quality supervision stations or local building materials associations review the application.

4. If approved, the company and its products will be added to the database.

The review and approval of the application occurs at the province or city level, as the requirements for building materials may differ by province or city. For example, a company in the energy efficient building material database for Shanghai needs to have their products rated or certified by the Shanghai Building Materials Association. Since the building material database is region-specific, management of the database also differs by region.

For some regions, architects are able to manually add additional materials to the database when they use PKPM to design buildings (Figure 3), and they need to provide testing results and certifications for these materials along with other documentations for plan review. In regions with more stringent policies on 
building materials such as Shanghai and Chongqing, the material database is locked and only contains an approved list of energy efficient materials and products.

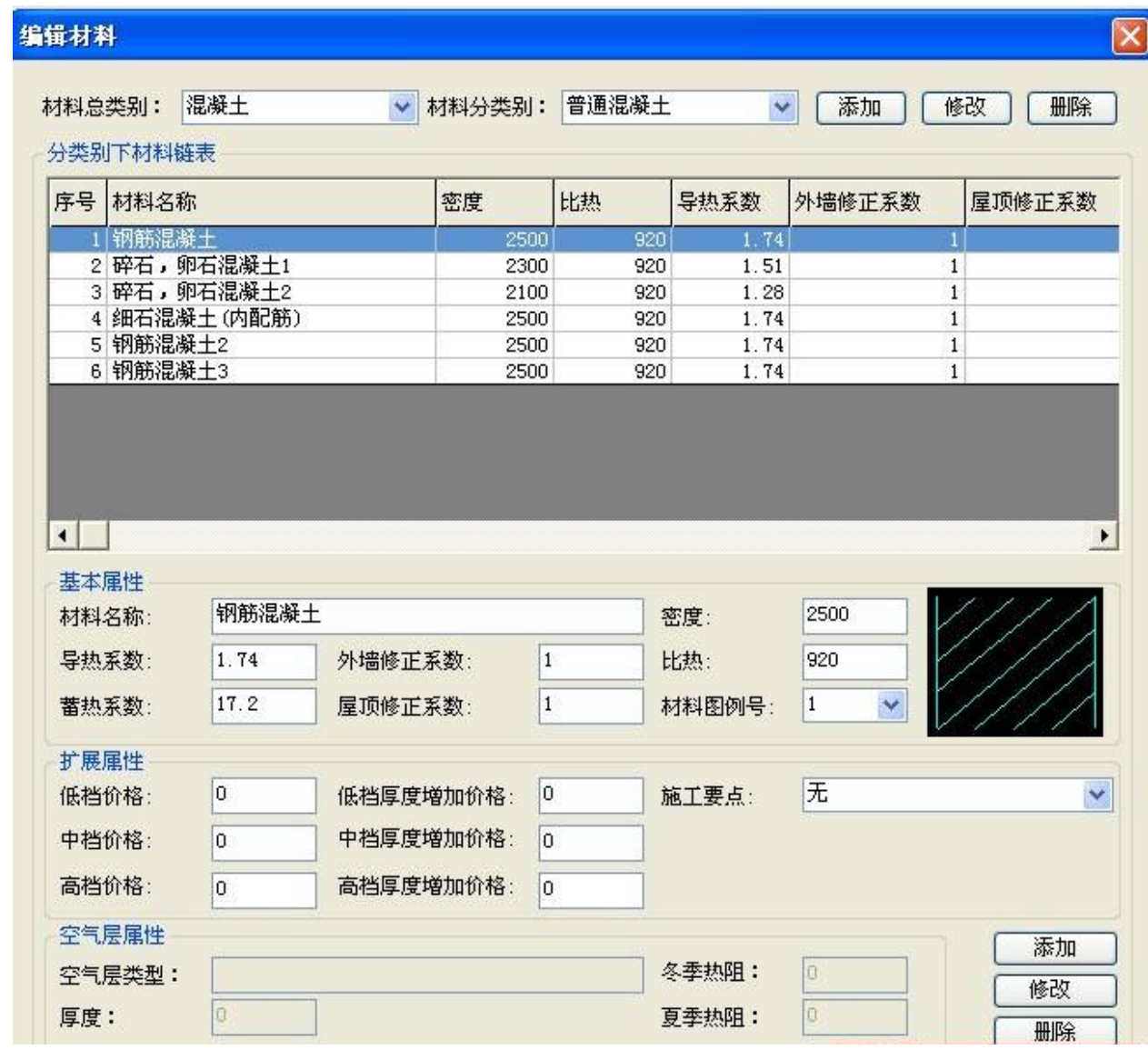

Figure 3: Editing the building material database

\section{Catalogs for Energy Efficient Building Materials}

The Green Building Action Plan ${ }^{17}$ released by the State Council in January 2013 encouraged the development of green building materials. It also requires the National Development and Reform Commission, the Ministry of Housing and Urban-Rural Development (MOHURD), the Ministry of Industry and Information Technology (MIIT), and the General Administration of Quality Supervision, Inspection and Quarantine to develop the green building material certification system and the green building material catalog. This system uses life-cycle analysis and considers energy use and emissions during material production. MOHURD and MIIT completed the draft standard for energy efficient glass in June 2013 and expected to release it by 2014. The ministries are still considering the final design of the catalog, including issues such as the scope, the host organization, and the promotion mechanisms. There are two approaches under consideration: 1) the catalog will only include types of building materials, not specific products; 2) the catalog, similar to the PKPM database, will include information of manufactures and specific products. In both cases, products of foreign companies will not be excluded from the catalog. Similar to many other product catalogs in China, the green building material catalog

\footnotetext{
${ }^{17}$ For details, please visit: http://www.gov.cn/zwgk/2013-01/06/content_2305793.htm.
} 
will be voluntary and companies applying to add their products to the catalog need to provide product certifications compliant with local professional associations. The catalog will initially focus on a few resource-intensive products - concrete, insulation materials, and glass - and expand over time.

MOHURD also plans to link the green building material catalog with China's Three-Star Green Building Rating system. While the system is voluntary, government incentives are helping to expand its use. Companies interested in the catalog may check with relevant departments in MOHURD and MIIT listed in the end.

In addition to the PKPM building material database and the green building material catalog, several provinces or cities have their own platform of building materials for government procurement.

MOHURD has developed a building material procurement platform for low-income housing, which links building material manufactures, appliance manufactures, developers, designers, inspection companies, and builders. It is free for companies to add their products to the platform but all companies need to provide certifications for their products and guarantee that prices they offer for low-income housing are lower than the market prices. MOHURD's Center for Housing Industrialization maintains the platform (Figure 4) and updates the ranks of products based on users' feedback and comments.

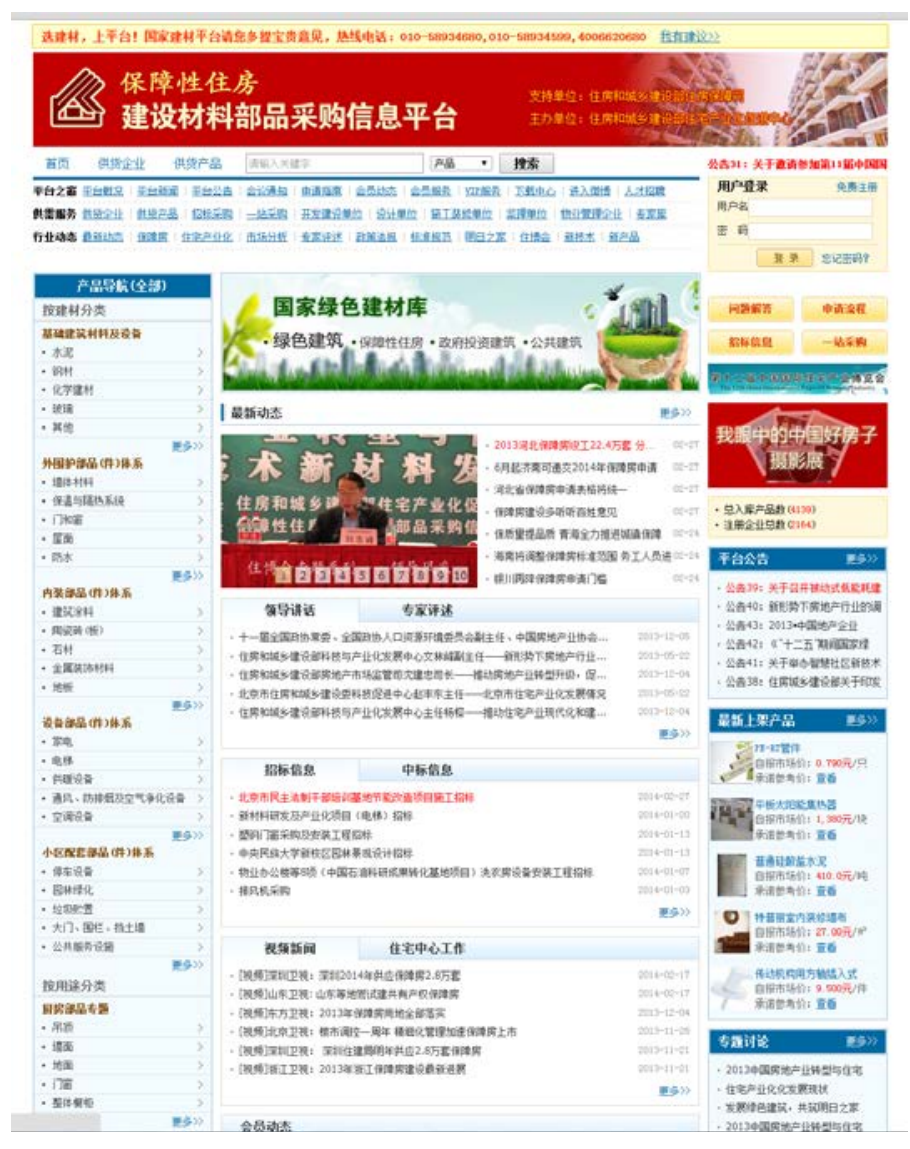

Figure 4: Procurement platform of building materials for low-income housing

(For details, please visit: http://www.chinahouse.org.cn/. The site is only available in Chinese.) 
The platform includes most building materials, including insulation systems, doors and windows, roofs, shadings, solar systems, ventilation systems, heat pumps, building automation systems, etc. To add building materials and products to the platform:

1. The company needs to register at www.chinahouse.org.cn.

2. The company fills in information about the company and its products online.

3. MOHURD's Center for Housing Industrialization reviews and approves the information provided by the company.

4. If approved, the company downloads the letter of commitment form the platform.

5. The company submits the signed letter of commitments, business license, tax registration certificate, and certificates for building materials and products to the Center for Housing Industrialization for final review.

6. If all documentations meet the requirements, the Center for Housing Industrialization approves the company's requests and adds relevant building materials and products to the platform.

Although most building material databases and catalogs are voluntary, products in these lists are certified by the government or professional associations and are more likely to be selected by designers and developers. The update of these lists is normally controlled by the organization developing and maintaining the lists, and companies that are interested in getting into these databases and catalogs are encouraged to directly contact these organizations.

\section{Contact Information}

PKPM-Energy (PKPM 建筑节能设计分析软件)

PKPM Shanghai Subsidiary

19th Floor Haili Building, No. 88 Dapu Road, Shanghai 200023, China

Tel: +86-21-53964807, +86-21-53964550

Fax: +86-21-53964839

E-mail: pub@pkpm.cn

Green Building Material Catalog（绿色建材产品目录）

Department of of Raw Materials, MIIT

No. 13 West Chang'an Street, Beijing 100084, China

Tel: +86-10-66012138

Department of Building Energy Efficiency and Technology, MOHURD

No. 9 Sanlihe Road, Beijing 100835, China

Tel: +86-10-58933043

Building Material Procurement Platform for Low-Income Housing

(保障性住房建设材料部品采购信息平台)

http://www.chinahouse.org.cn/

Center for Housing Industrialization, MOHURD

Room 210, No. 9 Sanlihe Road, Beijing 100835, China

Tel: +86-10-58934680, +86-10-58934599 


\section{Appendix C Energy Efficiency Retrofit for China Construction Bank Headquarter (Shared-Savings) \\ Project Background}

China Construction Bank (CCB) is one of the leading state-owned banks in China that provides full services in commercial banking. The headquarters building of CCB consumes resources including electricity, natural gas, water and space heating services. In 2006, total energy consumption of the headquarters building reached 5847 toe. By investing in energy efficient HVAC, lighting and control system as well as energy consumption information management system, the energy efficiency of the building has been greatly improved.

\section{Analysis on Financing Model and Economic Benefits}

Total energy and resource expense in 2006 is 15.2 million yuan, while the expected expense after retrofit is 11.7634 million yuan. The total annual energy savings equal 3.4 million yuan (Table C1).

Table C1. Baseline and expected expenditure after retrofit in 2006

\begin{tabular}{|l|c|c|c|c|c|c|}
\hline Resource & Unit & \multirow{2}{*}{$\begin{array}{c}\text { Unit Price } \\
\text { Type }\end{array}$} & & \multicolumn{2}{|c|}{ 2006 Baseline } & \multicolumn{2}{|c|}{ Expectation after Retrofit } \\
\cline { 4 - 7 } & & & Consumption & $\begin{array}{c}\text { Expenditure (in } \\
10,000 \text { yuan) }\end{array}$ & Consumption & $\begin{array}{c}\text { Expenditure (in } \\
10,000 \text { yuan) }\end{array}$ \\
\hline Electricity & $\mathrm{kWh}$ & 0.88 & $10,611,680$ & 934 & $8,016,290$ & 705 \\
\hline $\begin{array}{l}\text { Natural } \\
\text { Gas }\end{array}$ & $\mathrm{m}^{3}$ & 2.2 & $1,459,824$ & 321 & $1,174,517$ & 258 \\
\cline { 3 - 7 } & & $\begin{array}{c}2.4 \text { (gas for } \\
\text { cooking) }\end{array}$ & & & 33,510 & 8 \\
\hline Water & ton & 3.25 & 205,045 & 67 & 174,289 & 57 \\
\hline $\begin{array}{l}\text { Space } \\
\text { Heating }\end{array}$ & GJ & 30 & 65,700 & 197 & 49,275 & 148 \\
\hline Total & & & & 1,519 & & 1,176 \\
\hline
\end{tabular}

The total investment is 10 million yuan and 20\% of the investment comes from ESCO, while the rest is financed through loans from World Bank. The benefit of the retrofit differs in stages (Table C2).

Table C2. Benefit sharing scheme

\begin{tabular}{|l|c|c|c|c|}
\hline \multirow{2}{*}{$\begin{array}{l}\text { Year since the } \\
\text { retrofit }\end{array}$} & \multicolumn{2}{|c|}{ ESCO } & \multicolumn{2}{c|}{ CCB } \\
\cline { 2 - 5 } & Share & Benefits (in million yuan ) & Share & Benefits(in million yuan) \\
\hline $1 \sim 3$ & $90 \%$ & 9 & $10 \%$ & 1 \\
\hline $4 \sim 6$ & $80 \%$ & 8 & $20 \%$ & 2 \\
\hline $7 \sim 8$ & $70 \%$ & 5 & $30 \%$ & 2 \\
\hline $9 \sim 10$ & $60 \%$ & 4 & $40 \%$ & 3 \\
\hline Total & & 26 & & 8 \\
\hline
\end{tabular}

\section{Result and Evaluation}

After the retrofit, the building reduces its consumption by 2.5954 million $\mathrm{kWh}$ of electricity, 251,800 $\mathrm{m}^{3}$ of natural gas, 30,800 tons of water and 16,425 GJ of space heating annually, equivalent to 1,374 toe of energy consumption. It also reduces $\mathrm{CO}_{2}$ emission by 2,766 tons. 
Source: ERI. (2009). Market Survey Report on Current Financing Mechanism to Promote Existing Buildings Energy Efficiency in China. Beijing, China: Energy Research Institute of National Development and Reform Commission. 


\section{Appendix D Energy Efficiency Retrofit for Xijing Hospital in Xi'an City (Chauffage)}

\section{Project Background}

Xijing Hospital is one of the first class hospitals in Shanxi Province. With the development of the hospital, its energy and resource expense also increases significantly. In 2006, the hospital paid more than 49 million yuan for water, electricity, and steam consumption.

In order to reduce its energy and resource expenditure, Xijing hospital signed a whole energy system management contract with Beijing Aotianqi Energy Technology Co., Ltd. As the ESCO, Beijing Aotianqi would manage the whole energy system of Xijing hospital for 15 years. During the management, it would invest in steam generation equipment and its control system.

\section{Analysis on Financing Model and Economic Benefits}

As a Whole Energy Systems Management contract, the project is completely financed by the ESCO. The benefit of the retrofit differs in stages during the 15-year contract (Table D1).

Table D1. Benefit sharing scheme

\begin{tabular}{|l|c|c|}
\hline $\begin{array}{l}\text { Year since the } \\
\text { retrofit }\end{array}$ & ESCO’s Share & Xijing Hospital's Share \\
\hline $1 \sim 3$ & $80 \%$ & $20 \%$ \\
\hline $4 \sim 6$ & $70 \%$ & $30 \%$ \\
\hline $7 \sim 9$ & $60 \%$ & $40 \%$ \\
\hline $10 \sim 12$ & $50 \%$ & $50 \%$ \\
\hline $13 \sim 15$ & $40 \%$ & $60 \%$ \\
\hline Contract detail & Total Investment & Annual Payment \\
\cline { 2 - 3 } & 10.6 million yuan & 2 million yuan \\
\hline
\end{tabular}

The hospital reduced its energy expenditure by 11.45 million yuan and 12.17 million yuan respectively in 2007 and 2008 without any up-front investment (Table D2).

Table D2. Baseline and expected expenditure after retrofit in 2006

\begin{tabular}{|c|c|c|c|c|c|c|c|}
\hline \multirow[b]{2}{*}{ Date } & \multirow{2}{*}{$\begin{array}{c}\text { Total } \\
\text { Expenditure (in } \\
10,000 \text { yuan) }\end{array}$} & \multicolumn{2}{|c|}{ Water } & \multicolumn{2}{|c|}{ Steam } & \multicolumn{2}{|c|}{ Electricity } \\
\hline & & \begin{tabular}{|c|} 
Consumption (in \\
10,000 ton)
\end{tabular} & $\begin{array}{c}\text { Expenditure (in } \\
10,000 \text { yuan) }\end{array}$ & \begin{tabular}{|c|} 
Consumption (in \\
10,000 ton)
\end{tabular} & $\begin{array}{c}\text { Expenditure (in } \\
10,000 \text { yuan) }\end{array}$ & $\begin{array}{c}\text { Consumption (in } \\
10,000 \text { ton) }\end{array}$ & $\begin{array}{c}\text { Expenditure (in } \\
10,000 \text { yuan) }\end{array}$ \\
\hline 2006 & 4,397 & 249 & 676 & 26 & 2,023 & 4,073 & 1,699 \\
\hline Date & Benefits & \begin{tabular}{|c|} 
Conservation (in \\
10,000 ton)
\end{tabular} & $\begin{array}{c}\text { Benefits (in } \\
10,000 \text { yuan) }\end{array}$ & \begin{tabular}{|c|} 
Conservation (in \\
10,000 ton)
\end{tabular} & $\begin{array}{c}\text { Benefits (in } \\
10,000 \text { yuan) }\end{array}$ & $\begin{array}{c}\text { Conservation (in } \\
10,000 \mathrm{kWh} \text { ) }\end{array}$ & $\begin{array}{c}\text { Benefits (in } \\
10,000 \text { yuan) }\end{array}$ \\
\hline \begin{tabular}{|l} 
Dec. 2006 - \\
Nov. 2007 \\
\end{tabular} & 1,146 & 39 & 140 & 9 & 956 & 66 & 49 \\
\hline $\begin{array}{l}\text { Dec. } 2007 \text { - } \\
\text { Nov. } 2008\end{array}$ & 1,218 & 45 & 161 & 9 & 990 & 96 & 67 \\
\hline \begin{tabular}{|l} 
Total \\
Benefits
\end{tabular} & 2,364 & 84 & 301 & 18 & 1,946 & 162 & 116 \\
\hline
\end{tabular}




\section{Result and Evaluation}

After the retrofit, the building had reduced its consumption by 1.6153 million kWh of electricity, 178,400 tons of steam, 81,930 tons of water (as of the end of November 2008), equivalent to 16616.99 toe of energy consumption. It also reduced $\mathrm{CO}_{2}$ emission by 60,770 ton.

By the end of 2008, the ESCO had invested 5 million yuan to help save 18.90 million yuan of energy, of which the ESCO got 4.6 million yuan annually (Table D3).

Table D3. Actual benefit shared by ESCO and the hospital

\begin{tabular}{|c|c|c|c|c|c|}
\hline Year & $\begin{array}{c}\text { Investment } \\
\text { (in } 10,000 \\
\text { yuan) } \\
\end{array}$ & $\begin{array}{c}\text { Benefit (in } \\
10,000 \\
\text { yuan) }\end{array}$ & $\begin{array}{l}\text { Hospital's gain } \\
\text { (in } 10,000 \\
\text { yuan) }\end{array}$ & $\begin{array}{c}\text { ESCO's gain } \\
\text { (in 10,000 } \\
\text { yuan) }\end{array}$ & Notes \\
\hline 2006 & 300 & & & & Initial construction \\
\hline 2007 & 100 & 1145.87 & 299.17 & 916.70 & Annual operation \\
\hline 2008 & 100 & 1217.75 & 243.55 & 974.2 & and maintenance \\
\hline Total & 500 & 2363.62 & 472.72 & 1890.9 & $\begin{array}{c}\text { investment: } 1 \\
\text { million yuan }\end{array}$ \\
\hline $\begin{array}{l}\text { Hospital's } \\
\text { savings }\end{array}$ & \multicolumn{5}{|c|}{4.7272 million yuan } \\
\hline $\begin{array}{l}\text { ESCO's } \\
\text { profit }\end{array}$ & \multicolumn{5}{|c|}{$18.90-5=13.90$ million yuan } \\
\hline
\end{tabular}

Source: ERI. (2009). Market Survey Report on Current Financing Mechanism to Promote Existing Buildings Energy Efficiency in China. Beijing, China: Energy Research Institute of National Development and Reform Commission. 